\title{
USO DA TECNOLOGIA GPS NA MONITORAÇÃO DE DEFORMAÇÃO: SISTEMAS, ETAPAS E EXPERIMENTOS
}

\section{João Carlos Chaves}

Tese apresentada à Escola de Engenharia de São Carlos, da Universidade de São Paulo, como parte dos requisitos para obtenção do título de Doutor em Engenharia Civil: Transportes

ORIENTADOR: Prof. Dr. Paulo Cesar Lima Segantine 
Candidato: Engenthiciro JOÄO CARLOS CHAVES

Tese defendida e aprovada efr 23-03-2001 pela Comissto Julgadora:

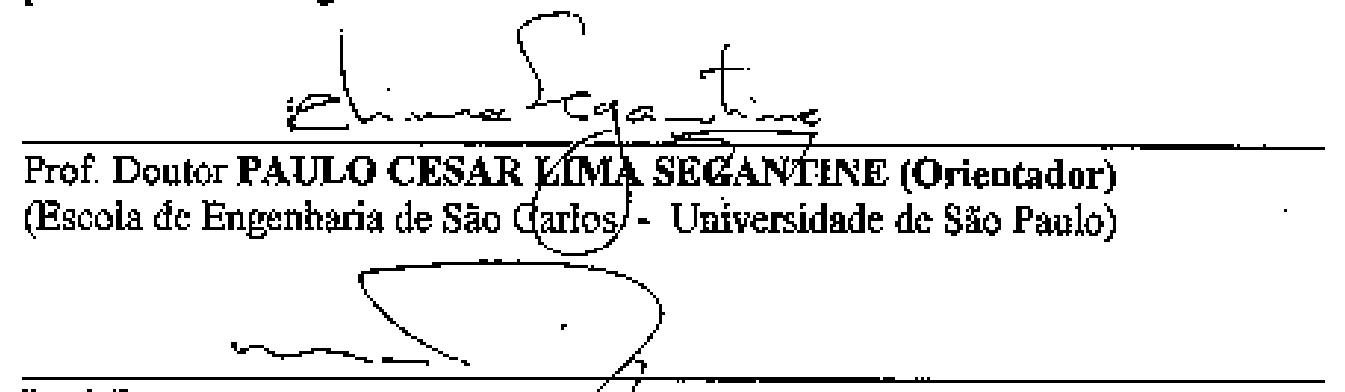

Prof. Doutor MAXIMILAANO MALITE

(Escola de Engerharia de Săo Carlos - Universidade de São Paulo)

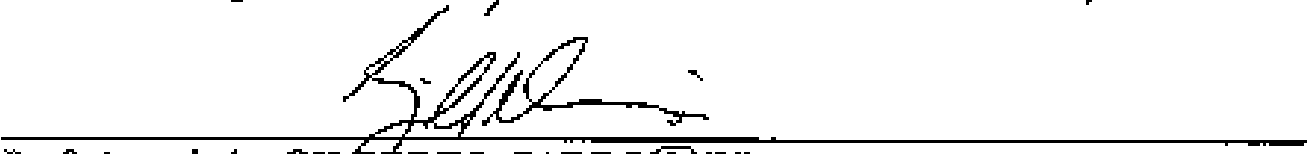

Prof. Associado GIbperTo CARBGNARI

(Universidade Estadual de Londrina - UEL)

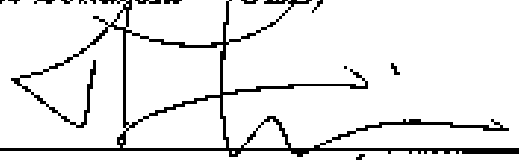

Prof. Associado JOAO FERNANDO CUSTÓDIO DA SILVA

(UNESP - Carnpus de Presidente Prudente)

\section{Sog timentet entra}

Prof. Associado JORGE PIMENTEL CINTRA

(Escola Polttécnica - Utiniversidade de Säo Paulo)

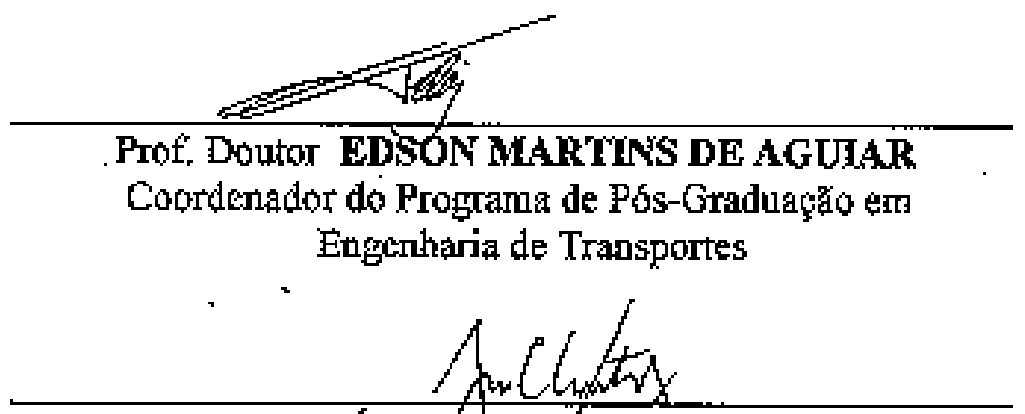

JOSÉ CARLOS A. CINTRA

Presidente da Comissäb de Pós-Graduaçăo da EESC 
Às minhas filhas, à minha esposa e aos meus pais. 
Agradeço a Deus pela minha vida e pela oportunidade de realizar esta pesquisa.

Ao Prof. Segantine pelos seus ensinamentos, orientações e sugestões.

À CAPES pela bolsa PICDT.

Ao Prof. Galera pelas sugestões, colaborações e pelo empréstimo do equipamento Z-XII, adquirido dentro do programa jovem pesquisador em Centros Emergente da FAPESP, processo 1995/08775-1.

Aos colegas do Departamento de Cartografia da FCT/UNESP.

Ao Prof. Mauro por colaborar com a disciplina Geodésia, durante o meu afastamento integral.

Aos eng. Carlos Alberto R. Dib e Luiz Antonio Correia da Constrinvest, por disponibilizar o acesso às dependências do edifício, no qual coletou-se dados para esta pesquisa.

Ao eng. Álvaro Ferro do DER, pela contribuição e disponibilização do viaduto para realizar os experimentos com o GPS.

Aos alunos Elivagner e Eugênio pela concessão dos dados GPS do TG.

Ao aluno Jardel pela colaboração nos levantamentos GPS no edifício.

Por todos que colaboraram com a realização deste trabalho.

À minha tia Alzira, pelas orações e incentivo.

Aos meus pais, João e Yolanda, pela minha existência e pelo exemplo de vida.

À minha fillha Mariana, pela sua compreensão.

À minha filha Carolina, pela sua sinceridade.

À minha esposa Eliana, pelo seu amor. 


\section{SUMÁRIO}

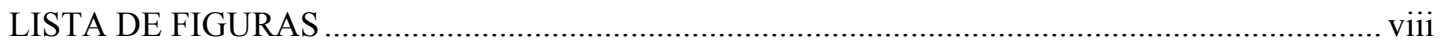

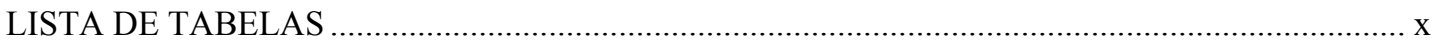

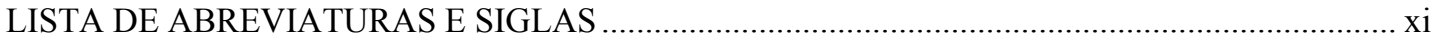

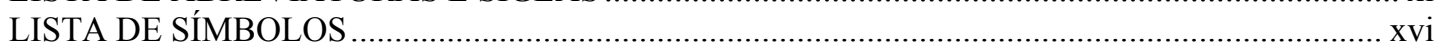

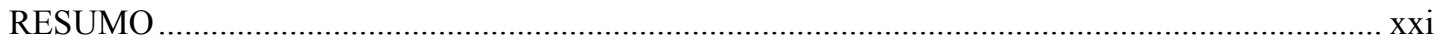

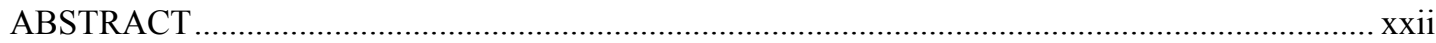

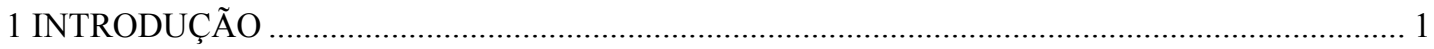

1.1 Importância e interesse pelo assunto ........................................................................................ 1

1.2 Exemplos de aplicações GPS em monitoração de deformação ……………………………................ 2

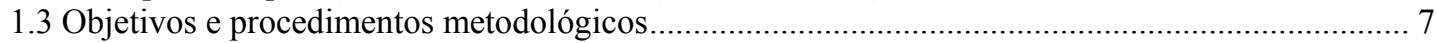

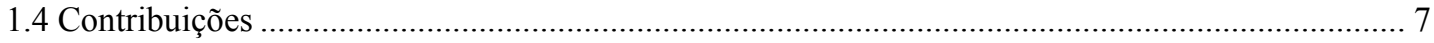

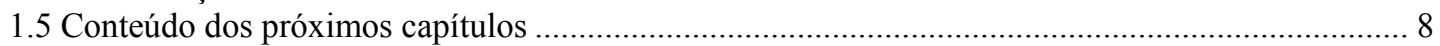

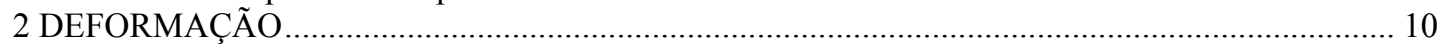

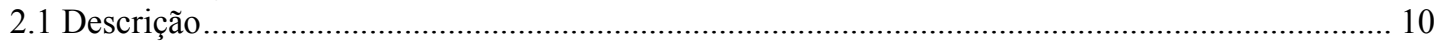

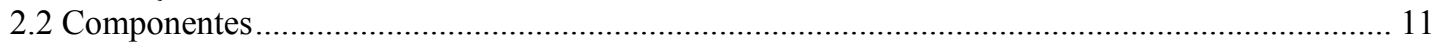

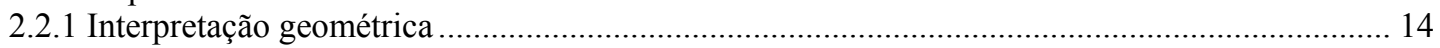

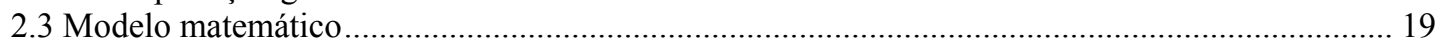

2.3.1 Relação com as observações .............................................................................................. 21

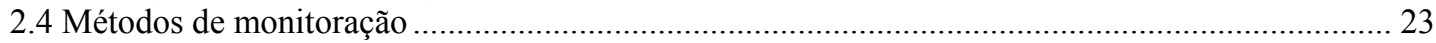

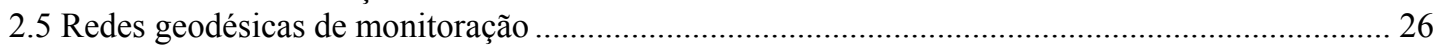

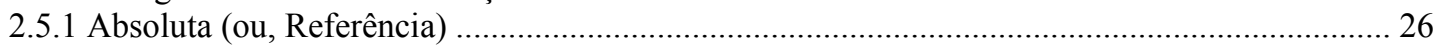

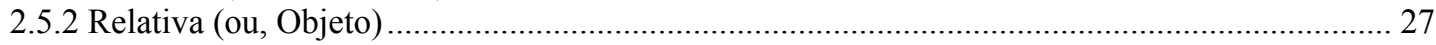

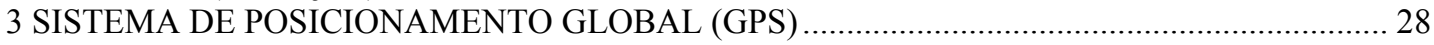

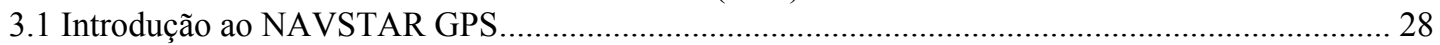

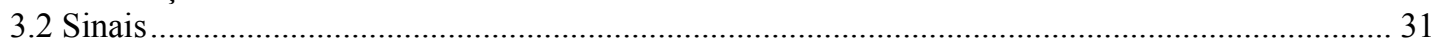

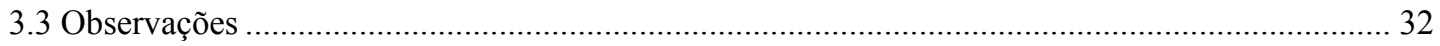

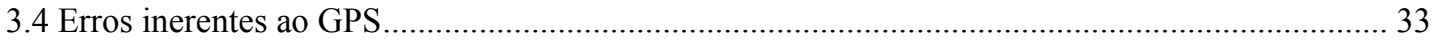

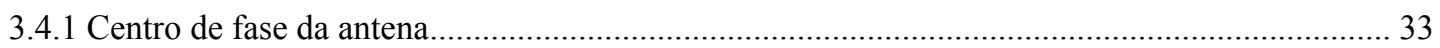

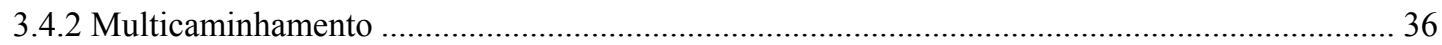

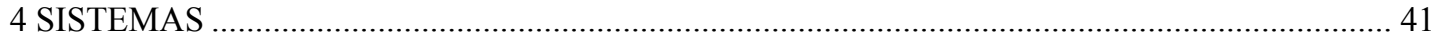

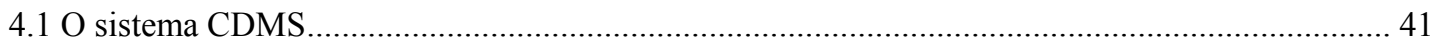

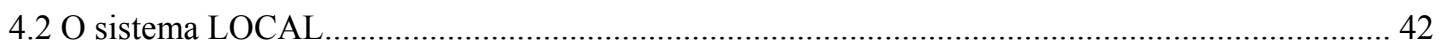

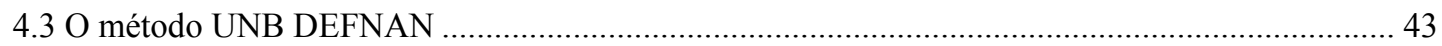

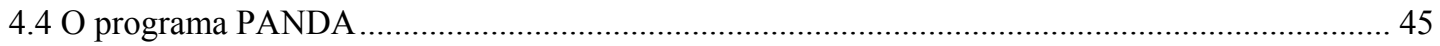

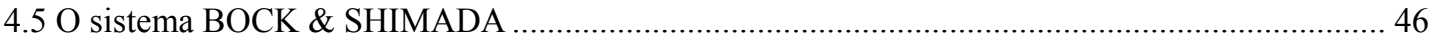

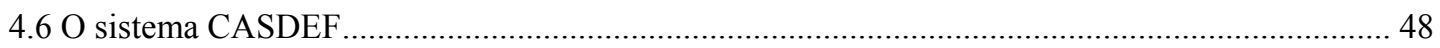

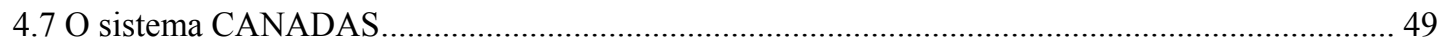

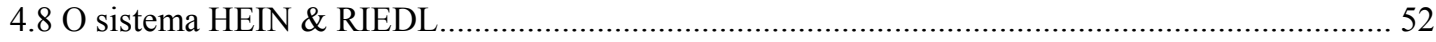

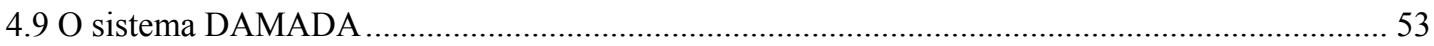

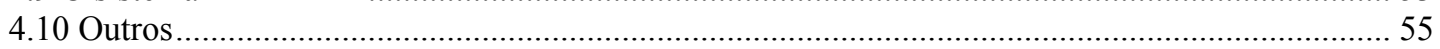

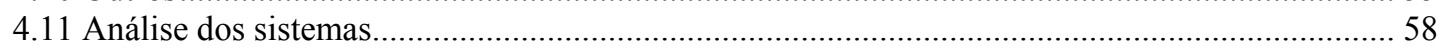

5 ETAPAS: otimização, observação, análise geométrica e interpretação ................................................6 60

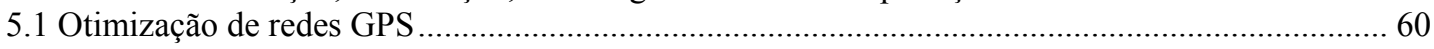

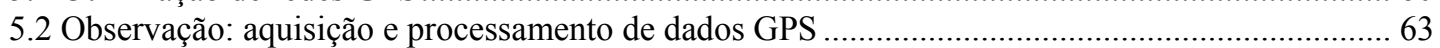


5.2.1 Aquisição, formatação e verificação dos dados GPS com receptores ASHTECH Z-XII, TRIMBLE 4600LS e TRIMBLE 4000SSI

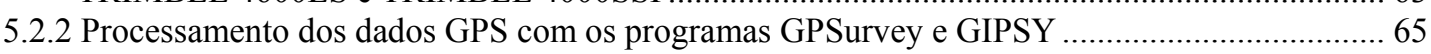

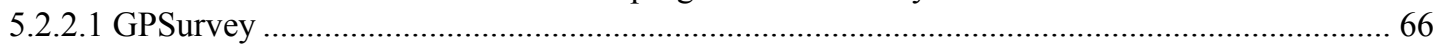

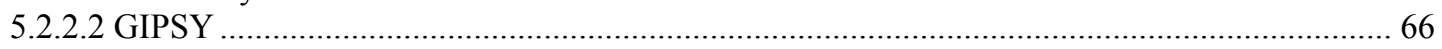

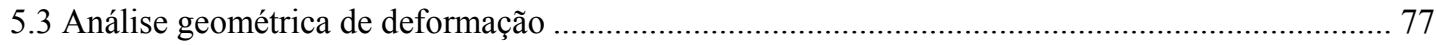

5.3.1 Seleção dos modelos de deformação ................................................................................ 78

5.3.2 Estimativa dos parâmetros de deformação dos modelos ....................................................... 80

5.3.3 Comparação e seleção dos modelos ....................................................................................... 81

5.3.4 Cálculo e representação das deformações ...................................................................... 81

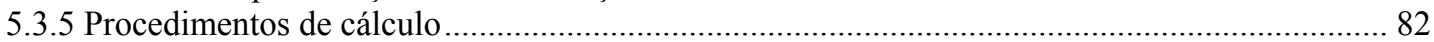

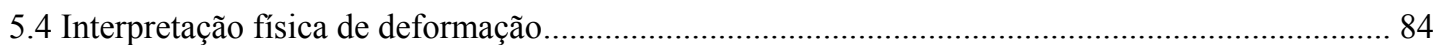

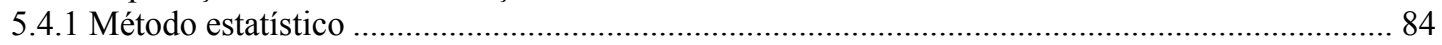

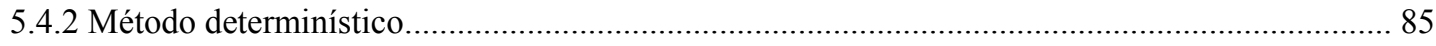

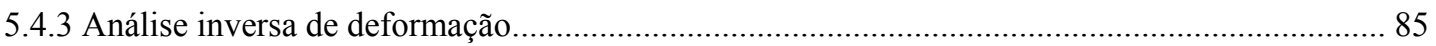

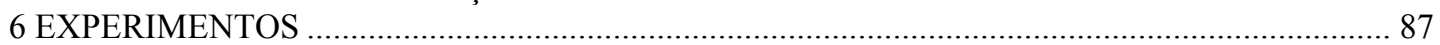

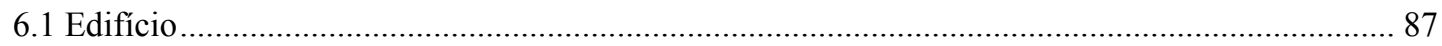

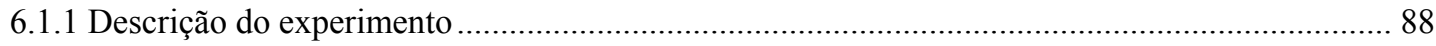

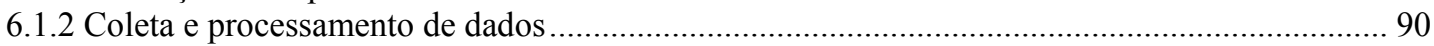

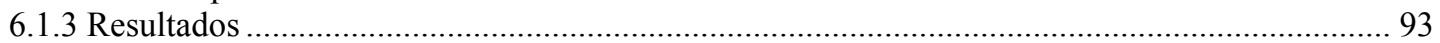

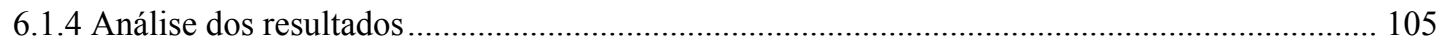

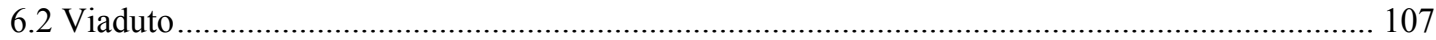

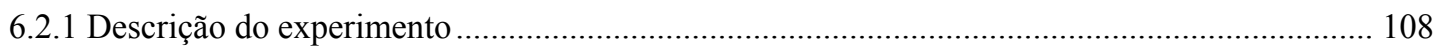

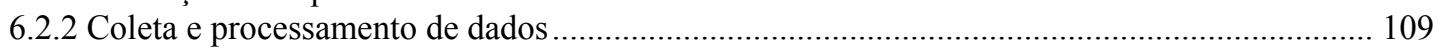

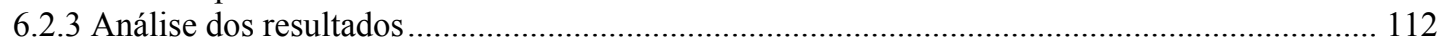

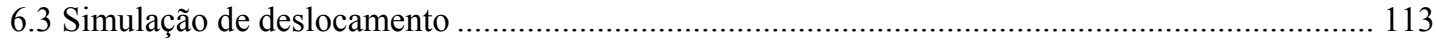

6.3.1 Descrição do experimento ................................................................................................. 113

6.3.2 Coleta e processamento de dados ....................................................................................... 114

6.3.3 Análise dos resultados ................................................................................................ 117

6.4 Simulação de estado de deformação .................................................................................... 118

6.4.1 Descrição do experimento ............................................................................................ 118

6.4.2 Coleta e processamento de dados ..................................................................................... 120

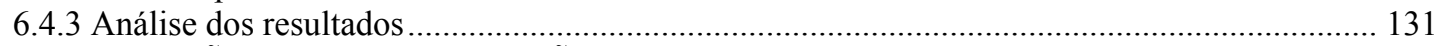

7 CONCLUSÕES E RECOMENDAÇÕES ............................................................................ 134

ANEXO A - Trecho inicial de um arquivo RINEX gerado com o TEQC ....................................... 137

ANEXO B - Arquivo gerado com o TEQC para controle de qualidade.......................................... 138

ANEXO C - Fluxograma e principais programas ................................................................. 140

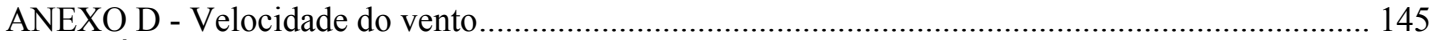

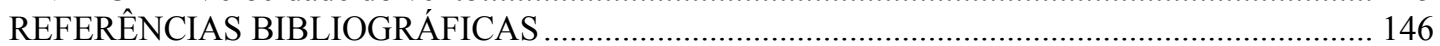

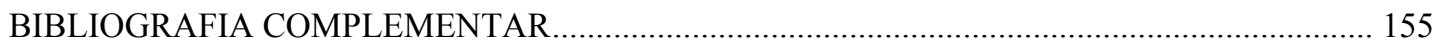




\section{LISTA DE FIGURAS}

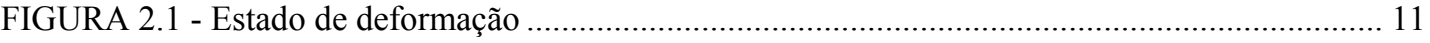

FIGURA 2.2 - Deformações pequenas em duas dimensões........................................................... 15

FIGURA 2.3 - Gradientes de deformação e interpretação de componentes (Adaptado de: FUNG,

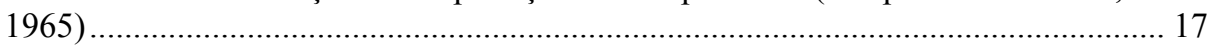

FIGURA 2.4 - Sistema tridimensional …................................................................................. 18

FIGURA 2.5 - Deformações angulares (Fonte: POPOV, 1968) …................................................. 19

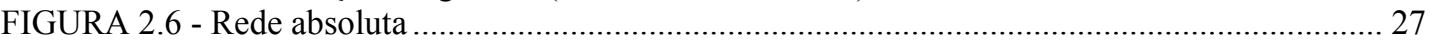

FIGURA 2.7 - Rede relativa …............................................................................................. 27

FIGURA 4.1 - Diagrama do método UNB DEFNAN (Adaptado de: CHRZANOWSKI et al., 1991) 44

FIGURA 4.2 - Programa PAN do PANDA (Adaptado de: NIEMEIER \& TENGEN, 1988) ............. 45

FIGURA 4.3 - Programa DEFANA do PANDA (Adaptado de: NIEMEIER \& TENGEN, 1988)...... 46

FIGURA 4.4 - Componentes de um sistema de monitoração (Adaptado de: BOCK \& SHIMADA, 1989).

FIGURA 4.5 - Fluxograma contendo os programas CASP, RAPP e CASPER (Adaptado de: MCLELLAN et al., 1989)..................................................................................... 49

FIGURA 4.6 - Fluxograma do programa MONALYSA do CANADAS (Adaptado de: TESKEY \& BIACS, 1991)

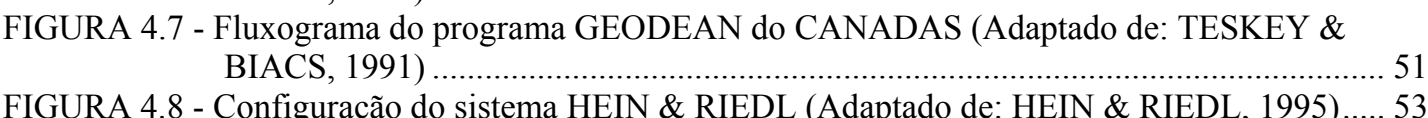

FIGURA 4.7 - Fluxograma do programa GEODEAN do CANADAS (Adaptado de: TESKEY \&
BIACS, 1991) ................................................................................... 51

FIGURA 4.9 - O sistema DAMADA (Adaptado de: SECORD, 1995) ......................................... 54

FIGURA 5.1 - Conexão ao computador ueppgps via telnet ...................................................... 72

FIGURA 5.2 - Acesso ao $x$ term ............................................................................................. 72

FIGURA 5.3 - Execução do GIPSY e opções de estratégias .......................................................... 73

FIGURA 5.4 - Escolha de um objetivo e definições de parâmetros.................................................. 74

FIGURA 5.5 - Exemplos de modelos de deformação (Adaptado de: CHEN, 1983) .........................8 80

FIGURA 5.6 - Esquema dos procedimentos de cálculo (Adaptado de: CHEN, 1983) ...................... 83

FIGURA 6.1 - Edifício Bali da Constrinvest .......................................................................... 87

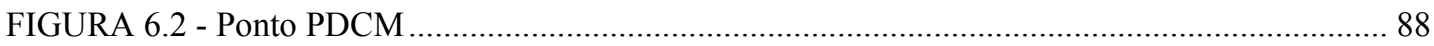

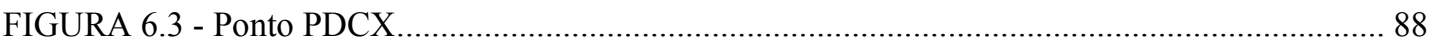

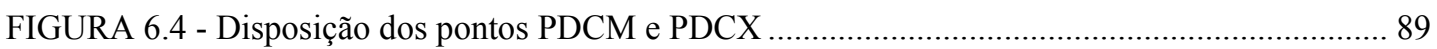

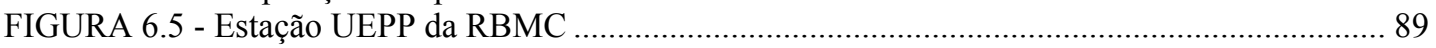

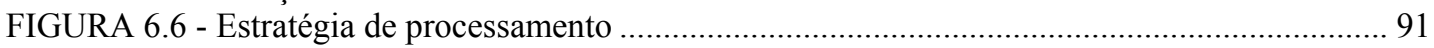

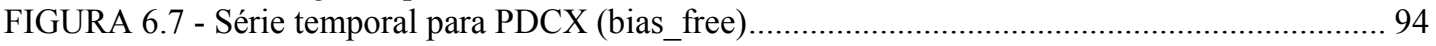

FIGURA 6.8 - Série temporal para UEPP (bias_free) ............................................................. 95

FIGURA 6.9 - Série temporal para PDCX (bias_fix) ................................................................. 95

FIGURA 6.10 - Série temporal para UEPP (bias_fix) ............................................................... 96

FIGURA 6.11 - Série temporal para PDCX (bfree_qitrf) .......................................................... 96

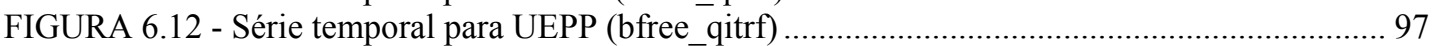

FIGURA 6.13 - Série temporal para PDCX (bfix_qitrf) ............................................................ 97

FIGURA 6.14 - Série temporal para UEPP (bfix_qitrf) .............................................................. 98

FIGURA 6.15 - Processamento cinemático para PDCX $(16 / 02 / 00)$................................................... 98

FIGURA 6.16 - Processamento cinemático para UEPP (16/02/00) .................................................... 99

FIGURA 6.17 - Processamento cinemático para PDCX $(17 / 02 / 00)$.................................................. 99

FIGURA 6.18 - Processamento cinemático para UEPP $(17 / 02 / 00)$.................................................. 100

FIGURA 6.19 - Processamento cinemático para PDCX $(18 / 02 / 00)$............................................... 100

FIGURA 6.20 - Processamento cinemático para UEPP (18/02/00) ................................................ 101 
FIGURA 6.21 - Processamento cinemático para PDCX (19/02/00) ................................................. 101

FIGURA 6.22 - Processamento cinemático para UEPP $(19 / 02 / 00)$.................................................... 102

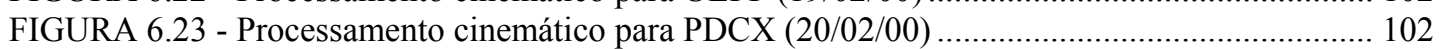

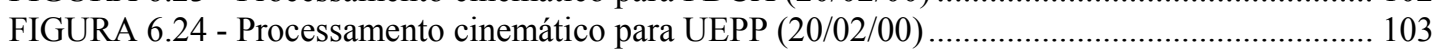

FIGURA 6.25 - Processamento cinemático para PDCM (11/02/00) ................................................. 103

FIGURA 6.26 - Processamento cinemático para UEPP (11/02/00) ................................................. 104

FIGURA 6.27 - Viaduto do DER ......................................................................................... 107

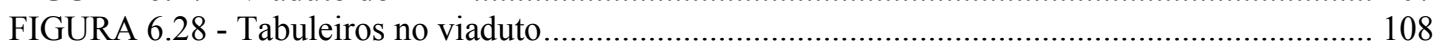

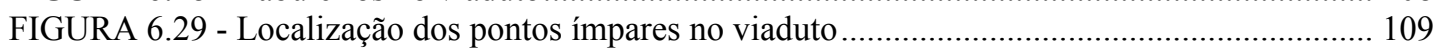

FIGURA 6.30 - Diferença de coordenadas geodésicas locais no viaduto ...................................... 110

FIGURA 6.31 - Componente Dn do viaduto, entre as épocas 31/01 e 03/02 ................................. 111

FIGURA 6.32 - Componente Dn do viaduto, entre as épocas 31/01 e 07/02 ................................. 111

FIGURA 6.33 - Componente Dn do viaduto, entre as épocas 03/02 e 07/02 ................................. 112

FIGURA 6.34 - Peça para simular deslocamento .................................................................... 113

FIGURA 6.35 - Colocação da peça de simulação de deslocamento no pilar EP02 ........................... 114

FIGURA 6.36 - Simulações de deslocamento............................................................................... 116

FIGURA 6.37 - Processamento cinemático das simulações de deslocamento ....................................... 116

FIGURA 6.38 - Variações do comprimento da base com processamento cinemático ....................... 117

FIGURA 6.39 - Placa para simular deformação ........................................................................... 118

FIGURA 6.40 - Simulação de deformação ................................................................................ 119

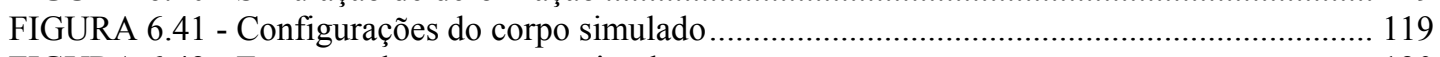

FIGURA 6.42 - Esquema das antenas na simulação ................................................................. 120

FIGURA 6.43 - Representação dos pontos processados para simular deformação........................... 121

FIGURA 6.44 - Configurações do segundo corpo simulado....................................................... 127

FIGURA 6.45 - Esquema das antenas na segunda simulação ...................................................... 128

FIGURA 6.46 - Representação dos pontos processados para simular deformação........................... 128

FIGURA C.1 - Fluxograma do GIPSY-OASIS II(Adaptado de: GREGORIUS, 1996) ...................... 140 


\section{LISTA DE TABELAS}

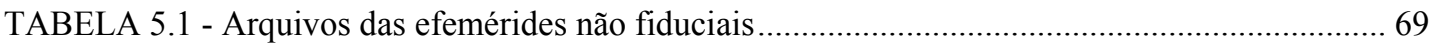

TABELA 5.2 - Tipos de receptores e antenas .......................................................................... 71

TABELA 6.1 - Repetibilidade das componentes da base PDCXUEPP ........................................... 93

TABELA 6.2 - Repetibilidade das componentes da base PDCMUEPP............................................ 94

TABELA 6.3 - Repetibilidade das componentes da base PDCXUEPP ......................................... 104

TABELA 6.4 - Repetibilidade das componentes da base PDCXUEPP c/ FIDUCIALS ................... 105

TABELA 6.5 - Simulações de deslocamentos .............................................................................. 115

TABELA 6.6 - Resultados das variações no comprimento da base EP02UEPP............................. 115

TABELA 6.7 - Teste de congruência para cada ponto, com base em UEPP .................................. 122

TABELA 6.8 - Teste de congruência para os pontos B e C, com base em A52 ............................ 123

TABELA 6.9 - Parâmetros de deformação (primeira simulação) ................................................... 124

TABELA 6.10 - Parâmetros adicionais (primeira simulação).......................................................... 126

TABELA 6.11 - Teste de congruência para cada ponto, com base em UEPP ................................ 129

TABELA 6.12 - Teste de congruência para os pontos B e C, com base em A63 ........................... 129

TABELA 6.13 - Parâmetros de deformação (segunda simulação)................................................. 130

TABELA 6.14 - Parâmetros adicionais (segunda simulação) .......................................................... 130

TABELA 6.15 - Deslocamentos simulados e estimados............................................................... 132 


\section{LISTA DE ABREVIATURAS E SIGLAS}

AFSC

AIUB

ALT

$A-S$

C.A.

$C / A$

CALTECH

CANADAS

CMS
$C D M S$

- U. S. Air Force Space Command (Comando Espacial da Força Aérea dos Estados Unidos)

- Astronomical Institute University of Berne (Instituto Astronômico da Universidade de Berne)

- altura geométrica

- Anti-Spoofing

- Ajustamento da campanha geodésica

- Coarse/Acquisition

- California Institute of Technology

- Computer Aided Network Aided Deformation Analysis System (Sistema de análise de deformação auxiliado por rede de computador)

- Continuous Deformation Monitoring System (Sistema contínuo de monitoração de deformação)

- Continuous Monitoring System (Sistema contínuo de monitoração)

CONSTRINVEST - Construtora e Comércio Ltda.

CORS

- Continuously Operating Reference Stations (Estações de referência de operação contínua)

D.M. - Análise integrada de deformação geométrica

DAMADA - DAta MAnagement for Deformation Analysis (Gerenciamento de dados para análise de deformação)

$d d \quad-$ dia

DER - Departamento de Estradas de Rodagem

DGPS - Diferential GPS/Diferencial GPS 
Dn

DoD

DOP

DORIS

DoT

Du

ECI

e-mail

EUA

FAA

FCT

FIG

FOC

fpo

FRP

FUNDACTE

$\mathrm{GC}$

GD

GEODEAN

GIPSY-OASIS II

GLONASS

GPS

I. G. R. S.
- diferenças de coordenadas geodésicas locais da componente norte

- Department of Defense (Departamento de Defesa)

- Dilution of Precision

- Doppler Orbitography and Radiopositioning Integrated by Satellite

- Departmente of Transportation (Departamento de Transportes)

- diferenças de coordenadas geodésicas locais

- Earth-Centered Inertial

- mensagem eletrônica

- Estados Unidos da América

- Federal Avionics Administration

- Faculdade de Ciências e Tecnologia

- Fédération Internatinale des Géomètres (International Federation of Surveyors; Internationale Vereinigung der vermessungsingenieure)

- Full Operational Capability (capacidade operacional total)

- fixed_precise_orbit

- Federal Radionavigation Plan (Plano Federal de Radionavegação)

- Fundação de Ciência, Tecnologia e Ensino de Presidente Prudente/SP

- coordenadas geocêntricas

- coordenadas geodésicas

- Geometric Deformation Analysis (Análise geométrica de deformação)

- GPS Inferred Positioning System - Orbit Analysis and SImulation Software

- GLObal NAvigation Satellite System

- Global Positioning System (Sistema de Posicionamento Global)

- Inversa Generalizada Reflexiva Simétrica 
IBGE

IOC

ITRF

$J P L$

$J P O$

$\angle A A F B$

LAT

LATOGEO

LC

LON

LTU

MB

Mbps

MCS

MED

MINQUE

MIT

$m m m$

MONALYSA

$M W D$

NAVSTAR

NEV

$N G S$

$n m l$

NRSS

OTF

PC
- Fundação Instituto Brasileiro de Geografia e Estatística

- Initial Operational Capability (Capacidade operacional inicial)

- International Terrestrial Reference Frame

- Jet Propulsion Laboratory

- Joint Program Office

- Los Angeles Air Force Base

- latitude

- Laboratório de Astronomia, Topografia e Geodésia

- combinação linear livre da ionosfera (ionosphere-free) para a fase da portadora

- longitude

- Lenght-Transverse-Up

- MegaByte

- milhões de dígitos binários ou "chips" por segundo

- Master Control Station (Estação principal de controle)

- Medidor Eletrônico de Distância

- MIinimum Norm Quadratic Unbiased Estimation

- Massachusetts Institute of Technology (Instituto de Tecnologia de Massachusetts)

- mês

- Monitoring Network Analysis and Adjustment (Análise e ajustamento de rede de monitoração)

- Metropolitan Water District of Southern California (Distrito de Água Metropolitano da Califórnia Meridional)

- NAVigation System with Timing And Ranging

- coordenadas geodésicas locais (Norte, Este e Vertical)

- National Geodetic Survey

- namelist

- normalised residual sum of squares

- On The Fly

- combinação linear livre da ionosfera (ionosphere-free) para a pseudodistância 


\begin{tabular}{|c|c|}
\hline PDCM & - ponto na casa de máquinas \\
\hline PDCX & - ponto na caixa d'água \\
\hline $\mathrm{ppb}$ & - parte por bilhão \\
\hline ppp & $\begin{array}{l}\text { - precise-point-position/posicionamento absoluto (por ponto) } \\
\text { preciso }\end{array}$ \\
\hline$P P S$ & $\begin{array}{l}\text { - Precise Positioning Service (Serviço de posicionamento } \\
\text { preciso) }\end{array}$ \\
\hline$P R N$ & - Pseudorandom Noise \\
\hline PVT & - Posição (tridimensional), Velocidade e Tempo \\
\hline$q m$ & - quick measurement \\
\hline RAD & - raio geocêntrico \\
\hline RBMC & - Rede Brasileira de Monitoramento Contínuo \\
\hline$R D O P$ & - Relative Dilution Of Precision \\
\hline RINEX & - Receiver Independent Exchange Format \\
\hline$R M S$ & - Root-Mean-Squares \\
\hline$R S S$ & - Rapid Static Survey \\
\hline S.S.A. & - Análise de série espacial e gráfico \\
\hline S.S.P. & - Análise de série espacial e gráfico \\
\hline S.T.A. & - Análise de tendência espacial e gráfico \\
\hline SA & - Selective Availabity \\
\hline$S C I G N$ & $\begin{array}{l}\text { - Southern California Integrated GPS Network (Rede GPS } \\
\text { integrada no sudeste da Califórnia, EUA) }\end{array}$ \\
\hline$S L R$ & - Satellite Laser Ranging \\
\hline SPS & $\begin{array}{l}\text { - Standard Positioning Service (Serviço de posicionamento } \\
\text { padrão) }\end{array}$ \\
\hline SRIF & - Square Root Information Filter \\
\hline T.S.A. & - Análise de tendência de série temporal e gráfico \\
\hline T.S.P. & - Análise de série temporal e gráfico \\
\hline TAGNET & - Terrestrial And Gps NETwork (Rede terrestre e GPS) \\
\hline telnet & $\begin{array}{l}\text { - protocolo usado na Internet para permitir que um computador } \\
\text { acesse outro }\end{array}$ \\
\hline$T E Q C$ & - Translate/Edit/Quality Check \\
\hline
\end{tabular}


TRIMBLE

UFScar

UNAVCO

$U N B$

UNESP

UNIX

USACE

USAETL

USCG

USNO

USP

UTC

$V F$

$V L B I$

VMS

WCDA

WGS84

$\mathrm{XYZ}$

yy
- Trimble Navigation Limited

- Universidade Federal de São Carlos

- University NAVSTAR Consortium

- University of New Brunswick, Geodesy and Geomatics Engineering Department (Universidade de New Brunswick, Departamento de Geodésia e Engenharia Geomática)

- Universidade Estadual Paulista

- Sistema operacional em estações de trabalho Sun e HP

- U. S. Army Corps of Engineers (Engenheiros do exército dos EUA)

- U. S. Army Engineer Topographic Laboratories (Engenheiros dos laboratórios de Topografia do exército dos EUA)

- United States Coast Guard

- United States Naval Observatory

- Universidade de São Paulo

- Universal Time Coordinate (Tempo Universal Coordenado)

- Variance Factor

- Very Long Baseline Interferometry

- Sistema operacional para máquinas VAX

- Western Canada Deformation Array (Rede de deformação do oeste do Canada)

- World Geodetic System 1984 (Sistema Geodésico Mundial 1984)

- coordenadas cartesianas

- ano 


\section{LISTA DE SÍMBOLOS}

$$
\begin{aligned}
& u_{i}, v_{i} \text { e } w_{i} \quad \text { - componentes de deslocamento do ponto com relação ao } \\
& \text { referencial cartesiano } X, Y \text { e } Z \text {, respectivamente } \\
& x_{i}(t), y_{i}(t) \text { e } z_{i}(t) \text { - coordenadas do ponto na época } t \\
& x_{i}\left(t_{0}\right), y_{i}\left(t_{0}\right) \text { e } z_{i}\left(t_{0}\right) \text { - coordenadas do ponto na época } t_{0} \\
& \left(\varepsilon_{x}=\varepsilon_{x x}\right) \quad \text { - alongamento unitário na direção } X \\
& \left(\varepsilon_{y}=\varepsilon_{y y}\right) \quad \text { - alongamento unitário na direção } Y \\
& \left(\varepsilon_{z}=\varepsilon_{z z}\right) \quad \text { - alongamento unitário na direção } Z \\
& \text { b - ambigüidade } \\
& \beta_{i j} \quad \text { - ângulo vertical entre dois pontos } \\
& \alpha_{\gamma} \quad-\text { azimute de } \gamma \\
& \alpha_{\max } \quad \text { - azimute de } \varepsilon_{\max } \\
& \alpha_{i j} \quad \text { - azimute entre os dois pontos } \\
& r\left\{P_{i}\right\} \quad \text { - característica da matriz peso } \\
& \text { h - característica da matriz variância-covariância do vetor } \\
& \text { deslocamento } \\
& \alpha_{e} \quad \text { - coeficiente ponderado para confiabilidade externa } \\
& \alpha_{i} \quad \text { - coeficiente ponderado para confiabilidade interna } \\
& \alpha_{c} \quad \text { - coeficiente ponderado para custo } \\
& \alpha_{p} \quad \text { - coeficiente ponderado para precisão } \\
& \left(u_{i}, v_{i}, w_{i}\right) \quad \text { - componentes de deslocamento do ponto } \\
& \left(a_{0} \text { e } b_{0} \text {, ou, } c_{0} \text { e } g_{0}\right) \text { - componentes do deslocamento do corpo rígido }
\end{aligned}
$$




\begin{tabular}{|c|c|}
\hline$\left(x^{\prime}, y^{\prime}, z^{\prime}\right)$ & - coordenadas finais \\
\hline$(x, y, z)$ & - coordenadas originais \\
\hline$\left(\varepsilon_{i j}\right)$ & - deformação pura; tensor de deformação pequena \\
\hline$\hat{u}$ & - deslocamentos dos pontos \\
\hline$z$ & - diferença entre o valor observado e o calculado \\
\hline$\Delta$ & - dilatação ou divergência do vetor deslocamento \\
\hline$u$ & - dimensão do vetor das incógnitas \\
\hline$\rho$ & - distância entre as antenas do receptor e do satélite \\
\hline$S_{i j}$ & - distância espacial entre dois pontos \\
\hline$\varepsilon_{x y}(x, y)$ & - distorção \\
\hline$a_{2}$ & - distorção \\
\hline$\left(\gamma_{x y}\right)$ & - distorção ou deformação angular no plano $X Y$ \\
\hline$\left(\gamma_{x z}\right)$ & - distorção ou deformação angular no plano $X Z$ \\
\hline$\left(\gamma_{y z}\right)$ & - distorção ou deformação angular no plano $Y Z$ \\
\hline$v_{\sigma}$ & - erros das observações de tensão \\
\hline$v_{\varepsilon}$ & $\begin{array}{l}\text { - erros do vetor dos deslocamentos dos pontos nodais no } \\
\text { elemento }\left(d_{e}\right)\end{array}$ \\
\hline$\hat{c}$ & - estimativa dos parâmetros de deformação \\
\hline $\mathrm{L}$ & - fase da portadora \\
\hline$\sigma_{0}^{2}$ & - fator de variância a priori \\
\hline$\underline{d}(x, y)$ & - função deslocamento \\
\hline$\left(r_{j}, r_{K}\right)$ & - graus de liberdade no ajustamento de cada época \\
\hline$Q_{d}$ & - matriz cofatora do vetor deslocamento $(d)$ \\
\hline$Q_{x_{i}}$ & $\begin{array}{l}\text { - matriz cofatora do vetor deslocamento das coordenadas } \\
\text { ajustadas }\left(x_{i}\right) \text { para a época }(i)\end{array}$ \\
\hline$A$ & $\begin{array}{l}\text { - matriz configuração que relaciona as observáveis ao modelo } \\
\text { de deformação }(\partial l / \partial x) \text {, ou seja, matriz dos coeficientes das } \\
\text { equações de observação }\end{array}$ \\
\hline
\end{tabular}


$D$

$\mathrm{F}^{\prime}\left(\mathrm{x}_{0}\right)$

$A$

$B_{\varepsilon}$

$B$

C

K

$P_{d}$

$H_{e}$

$B_{e}$

$H_{g}$

$\varepsilon$

$\left(\omega_{i j}\right)$

$(\alpha)$

$d_{f}$

$\mathrm{Z}$

$\sigma$

$l_{g}$

$\mathrm{X}$

$\omega(x, y)$

$e$

$\left(x_{A}, y_{A}\right)$
- matriz constitutiva do material

- matriz das derivadas parciais de $\mathrm{x}_{0}$

- matriz das derivadas parciais dos parâmetros, também denominada de matriz configuração (matriz "design") $\left[\mathrm{F}^{\prime}\left(\mathrm{x}_{0}\right)\right]$,

- matriz das derivadas parciais dos polinômios com relação a

$x$ ou $y$

- matriz das derivadas parciais dos polinômios com relação às posições do ponto de observação (matriz configuração do modelo de deformação)

- matriz de elasticidade generalizada

- matriz em função das propriedades do material e da geometria do projeto

- matriz peso do vetor deslocamento $(d)$

- matriz transformação de $d$ para $d_{e}$

- matriz transformação deformação-deslocamento

- matriz transformação do vetor dos erros $\left(v_{g}\right)$

- medida de deformação num ponto do elemento

- movimento do corpo rígido; tensor de rotação

- nível de significância

- número de defeitos de datum restante e de defeitos de configuração que não são determinados numa época

- observações

- observações de tensão

- observações geométricas

- parâmetros

- parâmetros de rotação

- ponto de um elemento

- pontos localizados no bloco A 


\begin{tabular}{|c|c|}
\hline$\left(x_{B}, y_{B}\right)$ & - pontos localizados no bloco B \\
\hline $\mathrm{P}$ & - pseudodistância \\
\hline$\gamma$ & - resultante das componentes "shear strain" \\
\hline$\overline{A_{i} B_{i}}$ & - segmento de reta $(i=0,1,2)$ \\
\hline $\mathrm{r}$ & - soma dos graus de liberdade das épocas utilizadas \\
\hline$(t)$ & - tempo \\
\hline$u_{i, j}$ & - tensor; gradiente do vetor deslocamento \\
\hline$(\mathrm{T})$ & - valor calculado pelo teste estatístico \\
\hline$\left(\mathrm{F}_{\mathrm{h}, \mathrm{r}, \mathrm{\alpha}}\right)$ & - valor tabelado na distribuição de Fisher \\
\hline $\mathrm{x}_{0}$ & - valores nominais dos parâmetros do modelo \\
\hline$\left(\hat{\sigma}_{j}^{2}, \hat{\sigma}_{k}^{2}\right)$ & - variâncias em cada época \\
\hline $\mathrm{c}$ & - velocidade da luz \\
\hline$x$ & - vetor correção dos parâmetros $\left(\mathrm{x}-\mathrm{x}_{0}\right)$, \\
\hline$x$ & - vetor das coordenadas nos pontos associados com $l$ \\
\hline$\varepsilon$ & - vetor das deformações generalizadas \\
\hline$c$ & - vetor das incógnitas dos parâmetros de deformação \\
\hline$f$ & - vetor de carga \\
\hline$l$ & - vetor de observações \\
\hline$\tau$ & - vetor de tensão generalizada \\
\hline$(u)$ & - vetor deslocamento \\
\hline$x_{i}$ & - vetor deslocamento das coordenadas ajustadas \\
\hline$d$ & - vetor deslocamento do ponto $(x, y, z)$ \\
\hline$u$ & - vetor dos deslocamentos \\
\hline$d_{e}$ & - vetor dos deslocamentos dos pontos nodais no elemento \\
\hline$v_{g}$ & $\begin{array}{l}\text { - vetor dos erros (observações e modelo do método dos } \\
\text { elementos finitos) }\end{array}$ \\
\hline$v$ & - vetor dos resíduos \\
\hline$a_{1}$ e $b_{2}$ & - alongamentos unitários em cada direção \\
\hline
\end{tabular}




\begin{tabular}{|c|c|}
\hline $\mathrm{d}_{\text {ion }} \mathrm{e} \mathrm{d}_{\text {trop }}$ & - atrasos ionosférico e troposférico \\
\hline$\varepsilon_{x}(x, y)$ e $\varepsilon_{x}(x, y)$ & - componentes de alongamento unitário \\
\hline$\hat{X}_{j}$ e $\hat{X}_{K}$ & - coordenadas estimadas nas duas épocas \\
\hline dt e dT & - correções dos relógios do satélite e do receptor \\
\hline$\sum \hat{\mathrm{X}}_{\mathrm{j}}$ e $\sum \hat{\mathrm{X}}_{\mathrm{k}}$ & - matrizes variância-covariância de $\hat{X}_{j}$ e $\hat{X}_{K}$ \\
\hline$(\delta x, \delta y, \delta z)$ & - componentes de translação \\
\hline$\alpha, \beta, \gamma$ & - coordenadas generalizadas \\
\hline$(X, Y, Z)$ & - referencial cartesiano \\
\hline$\gamma_{1}, \gamma_{2}$ & - componentes "shear strain" (distorção) \\
\hline$\varepsilon_{\max }, \varepsilon_{\min }$ & - deformações principais (máxima e mínima) \\
\hline $\mathrm{C} / \mathrm{A}$ & - coarse/acquisition code/código grosseiro/aquisição \\
\hline $\mathrm{C} 1$ & - pseudodistância usando o código C/A em L1 \\
\hline D1, D2 & $\begin{array}{l}\text { - freqüências Doppler em cada freqüência de recepção do } \\
\text { sinal }\end{array}$ \\
\hline $\mathrm{L} 1$ & $\begin{array}{l}\text { - sinal de freqüência de rádio de banda } \mathrm{L} \text {, conhecida como } \\
\text { "Link" } 1(=1575,42 \mathrm{MHz})\end{array}$ \\
\hline L1, L2 & - medida de fase em cada freqüência \\
\hline $\mathrm{L} 2$ & $\begin{array}{l}\text { - sinal de freqüência de rádio de banda } \mathrm{L} \text {, conhecida como } \\
\text { "Link" } 2(=1227,6 \mathrm{MHz})\end{array}$ \\
\hline L5 & - quinta freqüência (= 1176,45 MHz) \\
\hline $\mathrm{P}$ & - precision code/código de precisão \\
\hline $\mathrm{P} 1, \mathrm{P} 2$ & - pseudodistância usando o código P em cada freqüência \\
\hline$\Delta$ & -ponto de referência \\
\hline 0 & -ponto objeto \\
\hline $\mathrm{T} 1, \mathrm{~T} 2$ & - Transit Doppler Integrado em $12^{\circ}(\mathrm{T} 1)$ e $400 \mathrm{MHz}(\mathrm{T} 2)$ \\
\hline
\end{tabular}




\section{RESUMO}

CHAVES, J.C. (2001). Uso da tecnologia GPS na monitoração de deformação: sistemas, etapas e experimentos. São Carlos, 2001, 155p. Tese (Doutorado) Escola de Engenharia de São Carlos, Universidade de São Paulo.

Compreender deformação e seus métodos de monitoração é essencial na prevenção de acidentes e na manutenção de obras de engenharia civil. O GPS vem se destacando como uma tecnologia poderosa no controle de deformações de estruturas. O objetivo desta pesquisa é fornecer parâmetros para análise do comportamento de uma estrutura, por meio de experimentos e simulações com o uso do GPS. Sistemas e etapas envolvidos na monitoração de deformação são revisados e apresentados. Com o programa científico GIPSY, obtém-se a repetibilidade e a série temporal dos pontos localizados num edifício. O comportamento dos tabuleiros de um viaduto é analisado, com base nos dados GPS. Determinação de deslocamentos e de parâmetros de deformação, torna-se possível, com a realização de simulações. Utiliza-se uma placa para simular estes parâmetros, os quais relacionam-se com as observações em função de um modelo matemático. Elementos adicionais, como dilatação e deformações principais, além de alongamentos unitários e distorções, são determinados. Para verificação de estabilidade, realiza-se o teste de congruência global.

Palavras-chave: GPS, deformação, monitoração, sistema, estrutura, deslocamento. 


\begin{abstract}
CHAVES, J.C. (2001) Use of GPS technology in the strain monitoring: systems, stages and experiments. São Carlos, 2001, 155p. Tese (Doutorado) - Escola de Engenharia de São Carlos, Universidade de São Paulo.
\end{abstract}

To understand strain and monitoring methods is essential in the prevention of accidents and in the maintenance of works of civil engineering. GPS has been increasingly becoming a powerful technology in the control of strains of structures. The aim of this research is to determine parameters for analysis of the behavior of a structure, by using simulation model and GPS. A review of systems and stages involved in the monitoring strain are revised and presented. With the scientific program GIPSY is obtained the repeatability and time series of the points located in a building. The behavior of the decks of a viaduct is analyzed with base in the data GPS. Determination of displacements and of strain parameters becomes possible with simulations. A plate is used to simulate these parameters and the mathematical model relates them with observations. Dilation or the principal strains are determined. In order to verify stability, it is carried out a global congruent test.

Keywords: GPS, strain, monitoring, system, structure, displacement. 


\section{INTRODUÇÃO}

\subsection{Importância e interesse pelo assunto}

A vida humana não tem preço e quando há notícias de que vítimas fatais ocorreram em acidentes, tais como desmoronamento de estruturas de engenharia civil, lamenta-se pelo fato e espera-se providência para evitar novas tragédias.

Durante o desenvolvimento desta pesquisa, ocorreram quedas de edifícios, $\mathrm{p}$. ex.: o edifício Itália em São José do Rio Preto - SP, de 17 andares, em outubro de 1997 (fase final da construção); o edifício Palace 2, na Barra da Tijuca, Rio de Janeiro - RJ, de 22 andares, em fevereiro de 1998 (obra nova); e o edifício Erika, em Recife - PE, de 3 andares, em novembro de 1999. Nestes exemplos, aconteceram perdas humanas e materiais. Seus moradores, certamente, nunca esquecerão deste dia, e seus construtores jamais serão esquecidos. Infelizmente, estes episódios aconteceram e podem suceder novamente em outras obras de engenharia civil.

Outro fato ocorrido, no decorrer deste trabalho, refere-se ao viaduto Engenheiro Alberto Badra, localizado na zona leste na cidade de São Paulo - SP, mais conhecido como elevado Aricanduva, com $1700 \mathrm{~m}$ de extensão, que teve esmagado um aparelho de apoio de um dos pilares que sustentam a via, em novembro de 2000, causando um desnível de aproximadamente $30 \mathrm{~cm}$ (considerado normal até $2 \mathrm{~cm}$ ) num dos seus tabuleiros, segundo SILVA (2001). Com o surgimento do desnível e a possibilidade da queda da estrutura, houve pânico entre os motoristas. Provavelmente, este fato ocorreu em virtude da falta de manutenção.

Estes tipos de estruturas de engenharia, convencionais (edifícios e viaduto), em conseqüência da falta de manutenção, ou do estado da obra (nova ou em fase final), não são ideais para elucidar esta pesquisa, porém são fatos que coincidiram com o 
desenvolvimento deste trabalho e que merecem destaques, já que ocorreram perdas humanas e materiais.

Além de edifícios e viadutos, outras obras, tais como barragens, pontes, torres e túneis, podem estar sujeitas, em decorrência de problemas estruturais, desde a simples interdição do local até perdas materiais e humanas.

Exemplo de uma grande obra de engenharia que pode exemplificar o uso desta pesquisa é a ponte Rio-Niterói. Em decorrência da falta de manutenção ou do tráfego, a estrutura desta obra deve ser monitorada para evitar a ocorrência de acidentes.

Assim, torna-se importante e essencial o estudo e emprego de métodos e tecnologias (p. ex.: o Sistema de Posicionamento Global - GPS) na monitoração de deformação, contribuindo sobremaneira com a prevenção de catástrofes envolvendo obras artificias e naturais.

O interesse por deformação, tema escolhido para esta pesquisa, existe desde a proposição tratada na dissertação apresentada à Escola Politécnica da Universidade de São Paulo, para obtenção do título de Mestre em Engenharia, junto à Área de Concentração: Engenharia de Transportes, intitulada Controle de deformação em barragens: métodos de monitoramento e viabilidade da utilização do GPS (CHAVES, 1994).

Diante das investigações realizadas na dissertação, a continuidade no assunto mostrou-se ser essencial, pois contribui para o melhor entendimento do tema escolhido.

\subsection{Exemplos de aplicações GPS em monitoração de deformação}

GOAD (1989) realizou experimentos com o propósito de investigar a viabilidade de utilizar o GPS (Global Positioning System) para a monitoração de barragem. Quatro receptores GPS foram utilizados no levantamento de uma barragem próxima de Lawrence, Kansas/EUA, medindo 42 alvos na crista da barragem. Dos quatro receptores, dois ficaram em posições fixas e os outros dois foram usados no modo cinemático. Goad queria descobrir se o pós-processamento dos dados coletados, num tempo de cinco minutos por ponto, poderia alcançar 
precisão centimétrica, valendo-se do conhecimento de uma base inicial para obter as ambigüidades inteiras. A conclusão de Goad foi de que a repetibilidadde centimétrica era alcançada quando valores de RDOP (Relative Dilution Of Precision) ficavam abaixo de $0,4 \mathrm{~m} /$ ciclo.

A utilização do GPS nos estudos de subsidência pode ser encontrado em STRANGE (1989). Levantamentos com GPS foram realizados para obter a exatidão com que a subsidência poderia ser determinada com base nas comparações entre as medidas GPS e os dados dos nivelamentos. A repetibilidade das determinações GPS de diferenças de alturas elipsoidais relativas durante um único levantamento foi de 1 a $2 \mathrm{~cm}$. Resultados diferenciais dos levantamentos GPS realizados durante 15 meses forneceram valores de subsidência que concordaram de 2 a $4 \mathrm{~cm}$ com aqueles obtidos do nivelamento. Também se utilizaram as alturas geoidais para converter as alturas elipsoidais derivadas do GPS em altitudes ortométricas do nivelamento, concordando em 3 a $7 \mathrm{~cm}$. Estes resultados mostraram que medidas repetidas com GPS podem ser usadas para monitorar futuras subsidências e que a comparação entre os resultados GPS com os nivelamentos existentes fornecem um informação valiosa sobre a antecedente subsidência na área de estudo.

A monitoração de uma ponte sobre o Rio Mississippi, próximo de New Orleans, Louisiana/EUA, foi realizado por LEACH et al. (1991). Este experimento foi patrocinado pelo Departamento de Transporte do Texas e conduzido com a cooperação e assistência do Departamento de Transporte e Desenvolvimento de Louisiana. Foram utilizados 12 receptores GPS Trimble 4000 SST, dos quais, dois foram colocados em locais estabelecidos como referência, distantes aproximadamente $1,6 \mathrm{~km}$ da ponte. Os dez receptores restantes foram colocados na ponte. O experimento foi realizado entre 13 e 16 de maio de 1991. O programa utilizado para o processamento da posição de cada antena foi o GPS22 do NGS (National Geodetic Survey), um subprograma do OMNI. A conclusão dos autores é de que o experimento demonstrou que o GPS pode ser empregado na medição do movimento de uma grande estrutura, tal como uma ponte. Embora fossem encontrados problemas com multicaminhamento (multipath), isso pode ser corrigido com estratégias para mitigar multicaminhamento numa implementação do sistema atual. 
Muitas técnicas geodésicas têm sido utilizadas para medir deformação da crosta no limite da placa, na Califórnia/EUA, conforme LARSON \& AGNEW (1991). Os dados mais antigos vêm das medidas de triangulação. Medidas precisas de distâncias eletrônicas têm fornecido dados sobre falhas no limite da placa. Estes procedimentos necessitam de intervisibilidade entre os pontos e estão limitados a distâncias de poucas dezenas de quilômetros. Na década passada, medidas usando objetos extraterrestres, tais como SLR (Satellite Laser Ranging) e VLBI (Very Long Baseline Interferometry) mediram distâncias entre pontos distantes de centenas a milhares de quilômetros. Avanços mais recentes nas medidas geodésicas de precisão têm usado o GPS. Os autores descrevem a precisão e a exatidão de bases de 50 a 450 $\mathrm{km}$. Os resultados encontrados confirmam que as medidas geodésicas GPS são apropriadas para experimentos de deformação da crosta (de milímetros a decímetros por ano). Outro exemplo de aplicação do GPS na monitoração de deformação da crosta pode ser encontrado em DONG \& BOCK (1989).

HOLLMANN \& WELSCH (1992) investigaram a viabilidade de observações GPS serem aplicadas em redes de engenharia de alta precisão. Uma pequena rede de monitoração de uma barragem, próximo a Dresden, Alemanha, foi observada com receptores GPS WM 102. Para controle de qualidade das observações GPS, a mesma rede foi observada com teodolito de precisão e com o mecômetro (EDM) 5000. As observações foram processadas e os resultados comparados, utilizando-se do método dos mínimos quadrados. As exatidões da rede terrestre foram de 0,25 mm (y), 0,19 mm (x), 1,31 mm (h), resultando num desvio padrão da distância inclinada de 0,47 mm (d). As observações GPS obtiveram os seguintes valores: 1,1 mm (y); 1,4 mm (x); 2,3 mm (h) e 2,5 mm (d). Uma das conclusões deste trabalho está relacionada com as observações GPS que são competitivas com as observações terrestres nas aplicações de projetos de engenharia de alta precisão. Na pequena rede local de monitoração da barragem de Rauschenbach, provou que as observações GPS podem ser utilizadas para demandas de exatidão de alguns milímetros.

A utilização do GPS na monitoração de barragens tem sido investigada pela comunidade internacional, de acordo com CHAVES (1994), por experiências com levantamentos estáticos e cinemáticos. Os resultados destas experiências são 
animadores e têm demonstrado que o GPS pode atender os projetos que demandam exatidões de alguns milímetros.

A monitoração de deformação dinâmica de estruturas, tais como longas pontes, torres, e grandes construções, para o propósito de determinar vibrações estruturais, é agora possível por GPS, segundo LOVSE et al. (1995). O interesse em vibrações de estruturas de engenharia civil tem advindo pelo fato de que atualmente existem mais estruturas altas e "esbeltas" do que no passado, e estas estruturas estão sendo projetadas com muito mais flexibilidade. Há também o fato de que a integridade estrutural deve ser verificada de tempo em tempo, e especialmente após eventos como incêndio ou terremoto. O experimento de LOVSE et al. (1995) trata da monitoração de deformação dinâmica (medida de vibrações estruturais) na Torre de Calgary, Alberta, Canadá, usando receptores GPS no modo diferencial. Os resultados mostraram claramente que é possível medir vibrações estruturais em grandes estruturas, usando o GPS. Também deve ser possível usar GPS para medir vibrações estruturais em outras grandes estruturas, tal como grandes pontes.

Com o objetivo de fornecer informações tridimensionais para o controle do movimento do corpo rígido e vibrações elásticas de uma estrutura, TEAGUE et al. (1995) utilizaram das diferenças das fases das portadoras do GPS para atingir a finalidade proposta. Recorrendo aos sinais que chegam em vários pares de antenas, além de um modelo dinâmico da estrutura, reconstitui o estado de deformação tridimensional de um sistema flexível. As conclusões deste trabalho indicam que o GPS é um sensor viável e importante para a deformação estrutural de sistemas com vibrações de centímetros e freqüências de 2 Hz. Em TEAGUE et al. (1996), os testes em laboratório com objetivo de medir movimento, também demonstraram que vibração e controle de orientação de veículos altamente flexíveis são obtidos com base nas fases das ondas portadoras do sistema GPS.

Determinar a sensibilidade das observações GPS nas áreas de litígio de terras reivindicadas e adotar o GPS para monitorar cortes em declives, barragens, túneis e outros projetos de construção, e determinar a estabilidade de locais foram os objetivos do trabalho de ANANGA et al. (1996). O levantamento foi realizado em quatro dias, de 21 a 24 de julho de 1993, em Port Island, Kobe, Japão. Uma rede com cinco pontos, distantes de 124 a $450 \mathrm{~m}$, foi observada com cinco receptores Trimble 
4000 SST, totalizando dez sessões. Destas, seis tiveram as posições das antenas deslocadas de $10 \mathrm{~mm}$ nas direções norte, este e vertical para testar a sensibilidade das observações GPS. Outra razão para deslocar a antena é para monitorar a rotação de um corte. Com base numa análise estatística dos resíduos de cada sessão observada, os autores concluíram que os resultados das diferenças de coordenadas indicam que a rotação dos pontos de controle são detectadas com o uso do GPS. A precisão das observações foi de $\pm 3 \mathrm{~mm}$. A análise estatística também indicou algumas influências sistemáticas desconhecidas nas diferenças de coordenadas da estação durante os quatro dias de observação, por causa dos movimentos do ponto de controle neste período. ANANGA \& KAWASHIMA (1995) também recomendam o uso do GPS em geomecânica, no lugar de usar somente instrumentos como inclinômetros, extensômetros e outros que fornecem medidas absolutas mas não deslocamentos relativos.

Os equipamentos para monitorar sistemas de estruturas, durante terremotos e ventos fortes, são os denominados acelerômetros. Porém, segundo ÇELEBI et al. (1998), para a obtenção dos deslocamentos, necessita-se de um processamento incluindo dupla integração, que em geral, requer decisões sobre qual filtro usar para processar o sinal. Estas escolhas podem introduzir erros nos períodos relevantes à resposta estrutural. Com a possibilidade de coletar dados GPS, numa taxa de 10 amostras por segundo, esta tecnologia permite monitorar estruturas, num longo período, tais como pontes suspensas e edifícios altos (de 20 a 40 pavimentos, ou mais). Este trabalho também está presente em ÇELEBI et al. (1999), descrevendo o experimento em duas barras verticais, com o mesmo comprimento $(1,82 \mathrm{~m}) \mathrm{e}$ larguras diferentes $(3,8 \mathrm{~cm} ; 5,0 \mathrm{~cm})$, para simular um edifício flexível de 30 a 40 pavimentos. Os resultados obtidos demonstram que a monitoração com o GPS em estruturas fornece deslocamentos relativos para este fim, e identifica as características dinâmicas do sistema de vibração.

Uma específica aplicação do GPS para a validação do modelo de elementos finitos, encontra-se em BROWN et al. (1999). Utilizando-se de uma ponte com modelo de elementos finitos desenvolvido para a sua monitoração, os deslocamentos desta estrutura são determinadas, com base nos dados GPS, e comparadas com as preditas pelo respectivo modelo. 
Esta combinação, GPS e análise de elementos finitos, conduz a outras aplicações, como p. ex. a monitoração contínua da condição de grandes estruturas, tornando-se essencial nos programas de monitoração e inspeção de obras de engenharia civil. ROBERTS et al. (1999) também relatam este experimento, concluindo que os resultados preliminares e suas análises estão permitindo aos pesquisadores desenvolver um método para monitoração e modelação de grandes estruturas.

\subsection{Objetivos e procedimentos metodológicos}

Os objetivos desta pesquisa são:

- analisar o uso do GPS na monitoração de deformação;

- verificar a eficiência do GPS em deformação.

Os procedimentos metodológicos para realizar esta pesquisa são:

- submeter os dados GPS ao processamento do programa científico GIPSY, com efemérides precisas não fiduciais do JPL, com o intuito de obter resultados (repetibilidade, série temporal, processamento cinemático) para a monitoração de dois pontos localizados num edifício de 18 pavimentos;

- investigar, com o GPS, a movimentação dos pontos localizados nos tabuleiros de um viaduto;

- simular, numa peça, os deslocamentos de um ponto e verificá-los com o uso de dados GPS processados com o GIPSY;

- projetar, executar e utilizar uma placa para simulação de deformação e determinação de seus parâmetros.

\subsection{Contribuições}

A comprovação da consolidação do GPS como parte integrante de sistemas destinados a monitorar deformações é apresentada, com base na descrição dos sistemas e de suas amplas e diversificadas aplicações.

Com a finalidade de cooperar com os usuários de levantamentos GPS para medir deformação, as etapas envolvidas com a realização dos mesmos são relatadas. 
Estas etapas constituem-se nas deliberações tomadas pela Comissão 6 da Federação Internacional de Geômetras (FIG - Fédération International des Géomètres, ou, International Federation of Surveyors) que tratam das análises dos levantamentos de deformações, segundo CHRZANOWSKI \& CHEN (1986).

O experimento realizado no edifício conduz a uma investigação sem precedentes no âmbito nacional, portanto de relevância para futuras pesquisas concernentes à monitoração de estruturas de engenharia. Salienta-se a utilização do programa científico GIPSY (GPS Inferred Positioning System), restrita no país, na monitoração do edifício e sua inédita aplicação neste assunto.

Certamente, a verificação periódica da movimentação dos tabuleiros, baseada nas diferenças de coordenadas dos pontos no viaduto, é de grande valia na prevenção de acidentes, como o do elevado Aricanduva.

Os resultados dos processamentos com o GIPSY, valendo-se das observações GPS efetuadas na peça para simular deslocamentos, podem confirmar a viabilidade desta tecnologia na respectiva simulação.

De maneira inusitada, a determinação dos parâmetros de deformação, com base na concepção do protótipo de simulação de deformação e na tecnologia GPS, é considerada relevante, pois é inexplorada para esta finalidade. Informações sobre dilatação e deformações principais, além das distorções e das componentes de alongamento unitário em cada direção, importantes para o especialista em estruturas, são obtidas neste experimento.

\subsection{Conteúdo dos próximos capítulos}

O segundo capítulo trata de deformação (teoria da elasticidade), descrevendo-a e apresentando suas componentes com a respectiva interpretação geométrica. O modelo matemático para deformação também é apresentado, relacionando as observações obtidas com base nos métodos de monitoração, com os parâmetros de deformação. Tanto os métodos quanto os tipos de redes geodésicas utilizados em monitoração são expostos.

No terceiro capitulo, exibe o Sistema de Posicionamento Global (GPS), seus sinais, suas observáveis e seus erros. 
O quarto capítulo descreve os sistemas, os métodos e os programas que processam os dados GPS na monitoração de deformação.

As etapas relacionadas com os levantamentos para fins de monitoração de deformação (otimização de redes; aquisição, tratamento e processamentos dos dados; análise geométrica e interpretação física) estão presentes no quinto capítulo.

Os experimentos desenvolvidos nesta pesquisa e suas respectivas análises estão no sexto capítulo. O sétimo capítulo relata as conclusões e as recomendações obtidas. 


\section{DEFORMAÇÃO}

Um corpo, ocupando uma região do espaço físico, tem uma configuração inicial definida pela sua posição com relação a um sistema de referência. Este corpo, quando submetido a ação de forças externas ou de tensões, sofre alterações na sua configuração original. VALLIAPPAN (1981) define esta mudança de configuração (estado inicial e final da geometria do corpo) por deformação.

\subsection{Descrição}

Os pontos de um corpo (perfeitamente elástico, homogêneo e isotrópico) com suas posições originais, ao movimentarem-se, ocupam novas posições. Estes movimentos (deslocamentos) correspondem às variações das coordenadas destes pontos com relação a um referencial. Os deslocamentos relativos entre os pontos resultam numa mudança de configuração, ou seja, numa deformação. Portanto, ao definir-se um vetor deslocamento de um corpo, descreve-se a deformação do mesmo.

Considere dois pontos $\left(A_{0}, B_{0}\right)$, próximos, num corpo antes de serem submetidos a um estado de deformação. Após sofrerem deformação, estes pontos movimentam-se para suas novas posições $\left(A_{1}, B_{1}\right)$, conforme a ilustração da FIGURA 2.1. A distância entre os pontos $A_{0}$ e $A_{1}$ corresponde ao deslocamento do ponto $A_{0}$. Analogamente, tem-se o deslocamento do ponto $B_{0}$. Se os segmentos $\overline{A_{0} B_{0}}$ e $\overline{A_{1} B_{1}}$ forem paralelos e as medidas dos comprimentos iguais, diz que ocorreu uma translação, ou seja, o segmento $\overline{A_{0} B_{0}}$ move-se rigidamente sem, no entanto, sofrer nenhuma deformação. Se os segmentos $\overline{A_{0} B_{0}}$ e $\overline{A_{1} B_{1}}$ não forem paralelos, significa que os pontos $A_{0}$ e $B_{0}$ movem-se para outras posições, diferentes 
de $\left(A_{1}, B_{1}\right)$, como por exemplo: $\left(A_{2}, B_{2}\right)$. Neste caso, se as medidas dos comprimentos dos segmentos $\overline{A_{0} B_{0}}$ e $\overline{A_{2} B_{2}}$ forem iguais, diz que ocorreu uma rotação. Caso contrário, ou seja, se os comprimentos dos segmentos $\overline{A_{0} B_{0}}$ e $\overline{A_{2} B_{2}}$ forem diferentes, pode-se afirmar que se tem um estado de deformação.

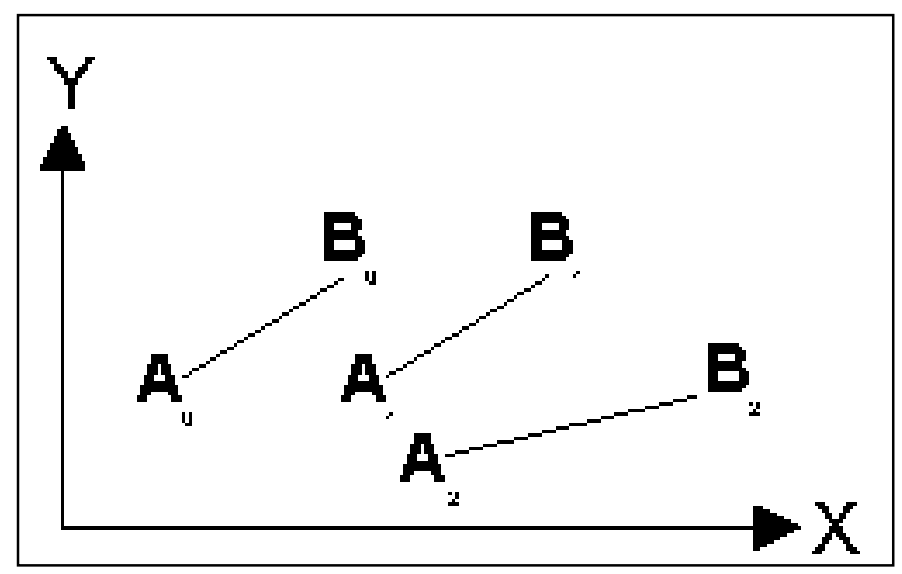

FIGURA 2.1 - Estado de deformação

As posições e os deslocamentos de cada ponto do corpo podem ser descritos em função de suas coordenadas originais $(x, y, z)$, ou, em função de suas coordenadas finais $\left(x^{\prime}, y^{\prime}, z^{\prime}\right)$, após o corpo sofrer deformação num tempo $(t)$. Estas descrições são conhecidas como descrição de Lagrange e descrição de Euler, respectivamente, conforme VALLIAPPAN (1981).

O vetor deslocamento $(u)$, quando definido pela descrição de Lagrange, é dado pela seguinte expressão:

$$
u=u(x, y, z, t),
$$

enquanto na descrição de Euler é dado por:

$$
u=u\left(x^{\prime}, y^{\prime}, z^{\prime}, t\right)
$$

\subsection{Componentes}

Considerando-se o referencial cartesiano $(X, Y, Z)$ e assumindo que os deslocamentos são funções contínuas das coordenadas, o tensor $u_{i, j}=\partial u_{i} / \partial x_{j}$ 
representa o gradiente do vetor deslocamento o qual pode ser decomposto em duas partes, uma simétrica $\left(\varepsilon_{i j}\right)$ e outra assimétrica $\left(\omega_{i j}\right)$, da seguinte forma:

$$
u_{i, j}=\varepsilon_{i j}+\omega_{i j}=\frac{1}{2}\left(u_{i, j}+u_{j, i}\right)+\frac{1}{2}\left(u_{i, j}-u_{j, i}\right) .
$$

VANÍCEK \& KWIMBERE (1988) denominam de simetrização a técnica mais popular para interpretar este tensor.

A parte simétrica $\left(\varepsilon_{i j}\right)$ representa a deformação pura num ponto e denomina-se tensor de deformação pequena, enquanto a parte assimétrica $\left(\omega_{i j}\right)$ representa o movimento do corpo rígido e denomina-se tensor de rotação. SOKOLNIKOFF (1946) refere-se a esta parte assimétrica como o deslocamento do corpo rígido, ou, deslocamentos rígidos, consistindo de translações e rotações. Estes tensores podem ser apresentados, conforme SKRZYPECK \& HETNARSKI (1993), da seguinte maneira:

$$
\varepsilon_{i j}=\left\{\begin{array}{ccc}
\frac{\partial u}{\partial x} & \frac{1}{2}\left(\frac{\partial u}{\partial y}+\frac{\partial v}{\partial x}\right) & \frac{1}{2}\left(\frac{\partial u}{\partial z}+\frac{\partial w}{\partial x}\right) \\
\frac{1}{2}\left(\frac{\partial v}{\partial x}+\frac{\partial u}{\partial y}\right) & \frac{\partial v}{\partial y} & \frac{1}{2}\left(\frac{\partial v}{\partial z}+\frac{\partial w}{\partial y}\right) \\
\frac{1}{2}\left(\frac{\partial w}{\partial x}+\frac{\partial u}{\partial z}\right) & \frac{1}{2}\left(\frac{\partial w}{\partial y}+\frac{\partial v}{\partial z}\right) & \frac{\partial w}{\partial z}
\end{array}\right\}
$$

e

$$
\omega_{i j}=\left\{\begin{array}{ccc}
0 & \frac{1}{2}\left(\frac{\partial u}{\partial y}-\frac{\partial v}{\partial x}\right) & \frac{1}{2}\left(\frac{\partial u}{\partial z}-\frac{\partial w}{\partial x}\right) \\
\frac{1}{2}\left(\frac{\partial v}{\partial x}-\frac{\partial u}{\partial y}\right) & 0 & \frac{1}{2}\left(\frac{\partial v}{\partial z}-\frac{\partial w}{\partial y}\right) \\
\frac{1}{2}\left(\frac{\partial w}{\partial x}-\frac{\partial u}{\partial z}\right) & \frac{1}{2}\left(\frac{\partial w}{\partial y}-\frac{\partial v}{\partial z}\right) & 0
\end{array}\right\}
$$

Para FUNG $(1965 ; 1994)$, estas rotações são assimétricas, isto é, $\omega_{i j}=-\omega_{j i}$, com isso, o tensor de rotações pode ser escrito como:

$$
\omega_{i j}=\left\{\begin{array}{ccc}
0 & -\omega_{y x} & -\omega_{z x} \\
\omega_{x y} & 0 & -\omega z y \\
\omega_{x z} & \omega_{y z} & 0
\end{array}\right\},
$$

onde, 


$$
\begin{aligned}
& \omega_{x y}=\frac{1}{2}\left(\frac{\partial v}{\partial x}-\frac{\partial u}{\partial y}\right), \\
& \omega_{x z}=\frac{1}{2}\left(\frac{\partial w}{\partial x}-\frac{\partial u}{\partial z}\right), \\
& \omega_{y z}=\frac{1}{2}\left(\frac{\partial w}{\partial y}-\frac{\partial v}{\partial z}\right) .
\end{aligned}
$$

Podem-se utilizar as notações indicial e de engenharia para as componentes do tensor de deformação pequena, de acordo com SKRZYPECK \& HETNARSKI (1993):

$$
\varepsilon_{i j}=\left\{\begin{array}{ccc}
\varepsilon_{x x} & \varepsilon_{y x} & \varepsilon_{z x} \\
\varepsilon_{x y} & \varepsilon_{y y} & \varepsilon_{z y} \\
\varepsilon_{x z} & \varepsilon_{y z} & \varepsilon_{z z}
\end{array}\right\}=\left\{\begin{array}{ccc}
\varepsilon_{x} & \frac{1}{2} \gamma_{y x} & \frac{1}{2} \gamma_{z x} \\
\frac{1}{2} \gamma_{x y} & \varepsilon_{y} & \frac{1}{2} \gamma_{z y} \\
\frac{1}{2} \gamma_{x z} & \frac{1}{2} \gamma_{y z} & \varepsilon_{z}
\end{array}\right\}
$$

Segundo TIMOSHENKO \& GOODIER (1980), as componentes de deformação na diagonal $\left(\varepsilon_{x}=\varepsilon_{x x}, \varepsilon_{y}=\varepsilon_{y y}, \varepsilon_{z}=\varepsilon_{z z}\right)$ representam os alongamentos unitários, deformações lineares unitárias ou deformações específicas no ponto, nas direções $X, Y$ e $Z$, respectivamente. As componentes que não pertencem a diagonal $\left(\gamma_{x y}, \gamma_{x z}, \gamma_{y z}\right)$, representam as deformações angulares, deformações por cisalhamento ou distorções relacionadas a estas mesmas direções. SKRZYPECK \& HETNARSKI (1993) interpretam as componentes fora da diagonal como sendo a metade da variação do ângulo reto entre os dois vetores originalmente direcionados ao longo dos eixos envolvidos.

As equações que relacionam as componentes de deformação $\left(\varepsilon_{x}, \varepsilon_{y}, \varepsilon_{z}, \gamma_{x y}, \gamma_{y z}, \gamma_{z x}\right)$ com as derivadas das componentes de deslocamento $(u, v, w)$, para o caso de deformações pequenas, infinitesimais, considerando um referencial cartesiano $(X, Y, Z)$, podem ser expressas como:

$$
\begin{aligned}
& \varepsilon_{\mathrm{x}}=\frac{\partial \mathrm{u}}{\partial \mathrm{x}} \\
& \varepsilon_{y}=\frac{\partial v}{\partial y}
\end{aligned}
$$




$$
\begin{aligned}
& \varepsilon_{z}=\frac{\partial w}{\partial z} \\
& \gamma_{x y}=\frac{\partial u}{\partial y}+\frac{\partial v}{\partial x} \\
& \gamma_{y z}=\frac{\partial v}{\partial z}+\frac{\partial w}{\partial y} \\
& \gamma_{z x}=\frac{\partial w}{\partial x}+\frac{\partial u}{\partial z}
\end{aligned}
$$

Assim, a deformação de um corpo é descrita por seis componentes de deformação: três alongamentos unitários $\left(\varepsilon_{x}, \varepsilon_{y}, \varepsilon_{z}\right)$ e três distorções $\left(\gamma_{x y}=\gamma_{y x}, \gamma_{y z}=\gamma_{z y}, \gamma_{z x}=\gamma_{x z}\right)$. Se descontinuidades existirem no corpo, as componentes de translação $(\delta x, \delta y, \delta z)$ e de rotação $\left(\omega_{x y}=\omega_{y x}, \omega_{x z}=\omega_{z x}, \omega_{y z}=\omega_{z y}\right)$ do corpo rígido devem ser consideradas. Portanto, considerando estas condições, tem-se um total de doze componentes de deformação.

\subsubsection{Interpretação geométrica}

A definição de deformação para os casos limitados a deslocamentos pequenos, infinitesimais, é dada por CADDELL (1980), como sendo a razão entre a diferença dos comprimentos antes e após a deformação pelo comprimento original. O estado de deformação, exemplificado na FIGURA 2.1, é definido como:

$$
\varepsilon \equiv \frac{\overline{A_{2} B_{2}}-\overline{A_{0} B_{0}}}{\overline{A_{0} B_{0}}} .
$$

Quando os deslocamentos forem grandes, as linhas que eram retas tornam-se curvas, em razão da rotação interna, segundo CADDELL (1980), complicando as equações de deformação, uma vez que tornam-se não lineares.

A FIGURA 2.2 ilustra o caso bidimensional para deformações e deslocamentos pequenos. Considere o retângulo constituído pelos pontos $A_{0}, B_{0}, C_{0}$, e $D_{0}$, com coordenadas referenciadas a um sistema cartesiano $(X, Y)$, definidos como $A_{0}(x, y), \quad B_{0}(x, y+d y), \quad C_{0}(x+d x, y)$ e $D_{0}(x+d x, y+d y)$. Supondo que estes pontos movimentam-se e ocupam novas posições $\left(A_{1}, B_{1}, C_{1}\right.$, e $\left.D_{1}\right)$, onde 
$A_{1}(x+u, y+v)$ e $C_{1}\left(x+d x+u+\frac{\partial u}{\partial x} d x, y+v+\frac{\partial v}{\partial x} d x\right)$ definem a linha cujo comprimento inicial era $\overline{A_{0} C_{0}}$. As componentes $(u, v)$ representam os deslocamentos nas direções $X$ e $Y$, respectivamente.

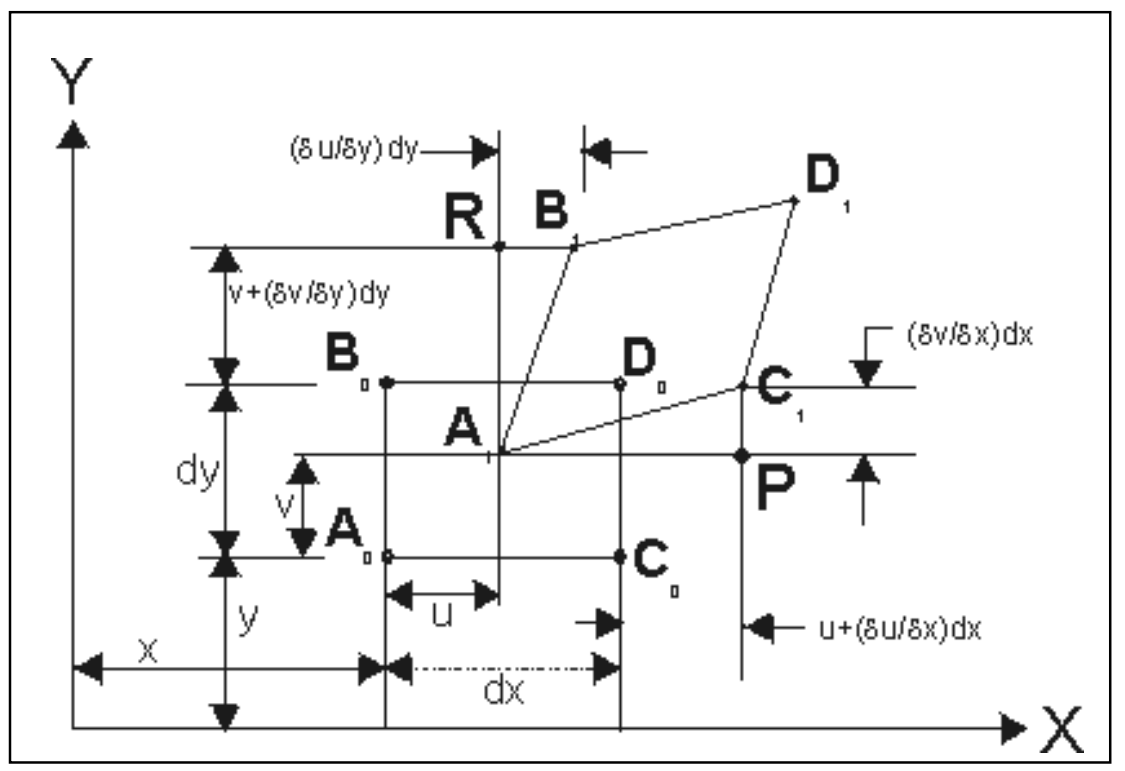

FIGURA 2.2 - Deformações pequenas em duas dimensões

Em razão dos deslocamentos serem considerados pequenos, pode-se admitir que $\overline{A_{1} C_{1}} \approx \overline{A_{1} P}$, sendo $P$ a projeção do ponto $C_{1}$ no eixo $X$, e que o ângulo formado pelos pontos $P A_{1} C_{1}$ é muito pequeno de modo que a tangente deste ângulo eqüivale ao próprio ângulo.

Utilizando a eq.(2.17), obtém-se o alongamento unitário na direção do eixo $X$ por:

$$
\varepsilon_{x} \equiv \frac{\overline{A_{1} C_{1}}-\overline{A_{0} C_{0}}}{\overline{A_{0} C_{0}}} \approx \frac{\overline{A_{1} P}}{\overline{A_{0} C_{0}}}-1=\frac{d x-u+u+\frac{\partial u}{\partial x} d x}{d x}-1=\frac{\partial u}{\partial x}
$$

Analogamente, obtém-se o alongamento unitário na direção $Y$ por:

$$
\varepsilon_{y}=\frac{\partial v}{\partial y}
$$

A distorção associada ao ponto $A_{0}$ corresponde à variação no ângulo formado pelos pontos $C_{0} A_{0} B_{0}$. Esta distorção é denotada por $\gamma_{x y}$, já que ocorre no plano $X Y$. 
A variação total no ângulo $C_{0} A_{0} B_{0}$ é igual a soma dos ângulos formados pelos pontos $R A_{1} B_{1}$ e $P A_{1} C_{1}$. $R$ é a projeção do ponto $B_{1}$ no eixo $Y$. O ângulo $P A_{1} C_{1}$ é obtido por:

$$
P A_{1} C_{1}=\arctan \frac{\frac{\partial v}{\partial x} d x}{\overline{A_{1} P}}=\arctan \frac{\frac{\partial v}{\partial x} d x}{d x+\frac{\partial u}{\partial x} d x}=\frac{\frac{\partial v}{\partial x} d x}{d x+\frac{\partial u}{\partial x} d x}=\frac{\partial v}{\partial x}
$$

desde que $\frac{\partial u}{\partial x}<<1$. Analogamente, pode-se obter o ângulo $R A_{1} B_{1}$ por:

$$
R A_{1} B_{1}=\frac{\partial u}{\partial y}
$$

A distorção $\gamma_{x y}$ é determinada por:

$$
\gamma_{x y}=\frac{\partial u}{\partial y}+\frac{\partial v}{\partial x}
$$

FUNG $(1965 ; 1994)$ ilustra o alongamento unitário na direção do eixo $X, \varepsilon_{x}$, e a distorção $\gamma_{x y}$ na FIGURA 2.3. O primeiro caso elucida $\varepsilon_{x}$, e os demais casos enfatizam $\gamma_{x y}$. 


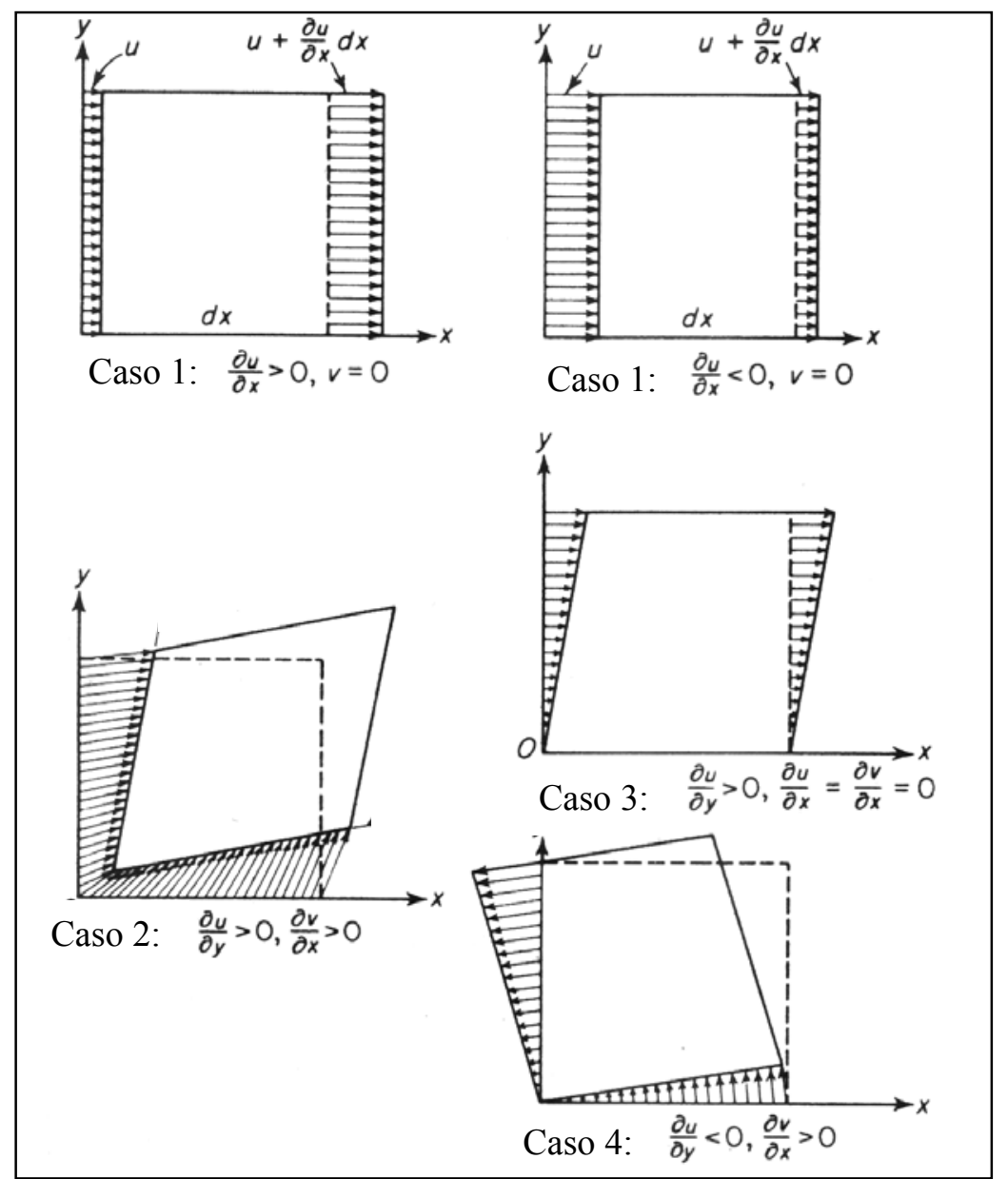

FIGURA 2.3 - Gradientes de deformação e interpretação de componentes (Adaptado de: FUNG, 1965)

No caso tridimensional, pode-se descrever o significado geométrico das deformações com relação a um paralelepípedo retangular, infinitesimal, cujas faces são, inicialmente, normais aos três eixos $(X, Y, Z)$ mutuamente perpendiculares, num referencial cartesiano, conforme FIGURA 2.4. 


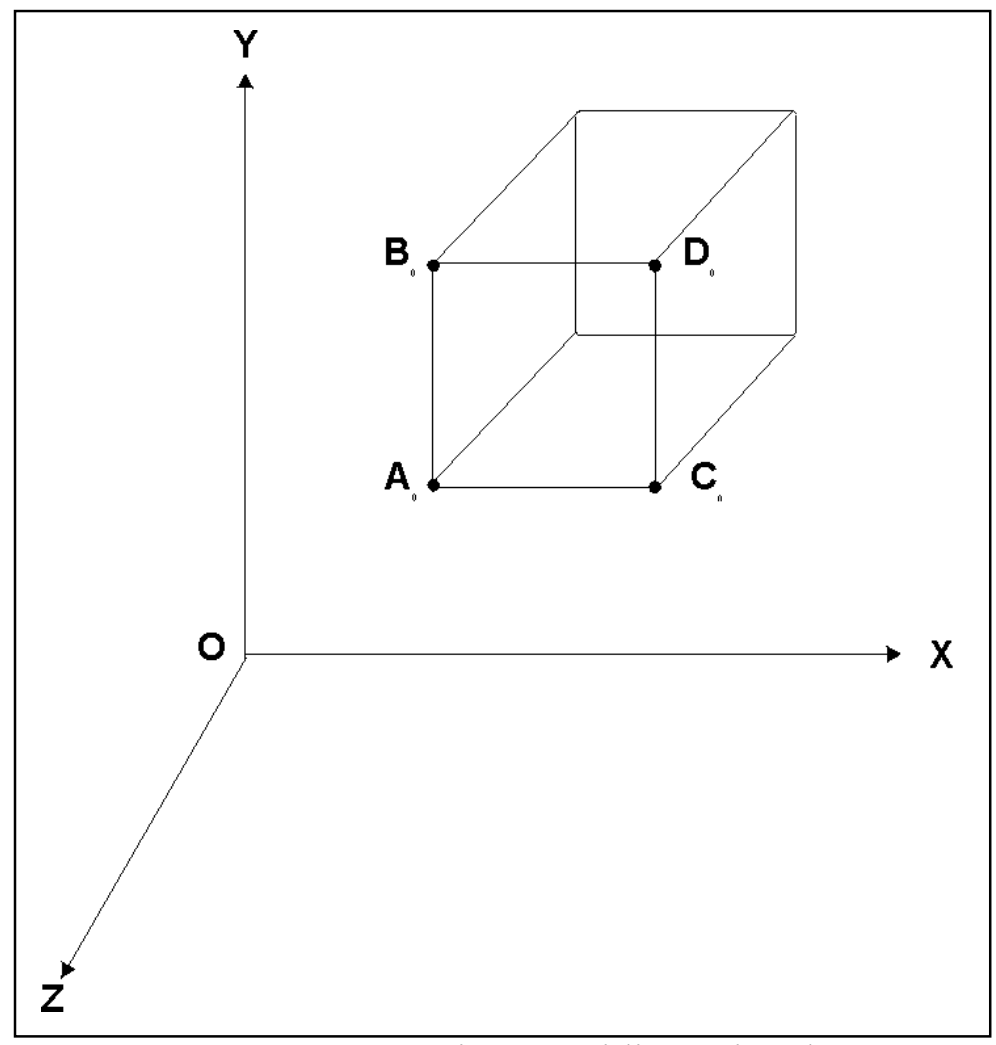

FIGURA 2.4 - Sistema tridimensional

A face $A_{0} B_{0} C_{0} D_{0}$ do paralelepípedo da FIGURA 2.4 refere-se à situação antes da deformação e é projetada no plano $X O Y$, e a situação após sofrer deformação é representada pela face $A_{1} B_{1} C_{1} D_{1}$, conforme visto no caso bidimensional na FIGURA 2.2 .

Portanto, o alongamento unitário na direção do eixo $X$ é:

$$
\varepsilon_{x}=\frac{\partial u}{\partial x}
$$

Para as direções $Y$ e $Z$, tem-se:

$$
\begin{aligned}
& \varepsilon_{y}=\frac{\partial v}{\partial y} \\
& \varepsilon_{z}=\frac{\partial w}{\partial z} .
\end{aligned}
$$

A deformação angular no plano $X O Y$, análogo ao caso bidimensional, é obtida por:

$$
\gamma_{x y}=\frac{\partial u}{\partial y}+\frac{\partial v}{\partial x}
$$


As deformações angulares nos planos $Y O Z$ e $X O Z$ são:

$$
\begin{aligned}
& \gamma_{y z}=\frac{\partial v}{\partial z}+\frac{\partial w}{\partial y}, \\
& \gamma_{z x}=\frac{\partial w}{\partial x}+\frac{\partial u}{\partial z} .
\end{aligned}
$$

A ilustração destas deformações angulares é apresentada por POPOV (1968), conforme a FIGURA 2.5.

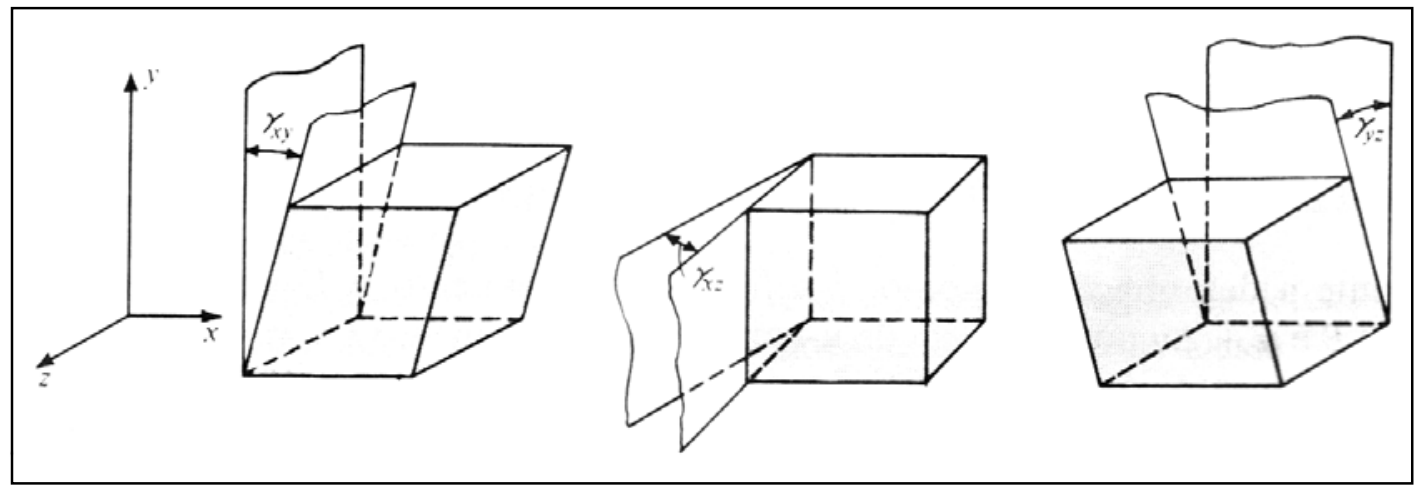

FIGURA 2.5 - Deformações angulares (Fonte: POPOV, 1968)

\subsection{Modelo matemático}

As componentes de deformação são determinadas com base nas observações realizadas em duas ou mais épocas. As observáveis relacionam-se com os parâmetros por meio de um modelo matemático que utiliza-se de polinômios para referirem-se aos deslocamentos. Segundo CHEN (1983), SECORD (1985) e KUANG (1991), este modelo de deformação pode ser apresentado por:

$$
d\left(x, y, z ; t-t_{0}\right)=B\left(x, y, z ; t-t_{0}\right) c
$$

ou,

$$
d\left(x, y, z ; t-t_{0}\right)=\left(\begin{array}{c}
u\left(x, y, z ; t-t_{0}\right) \\
v\left(x, y, z ; t-t_{0}\right) \\
w\left(x, y, z ; t-t_{0}\right)
\end{array}\right)=\left(\begin{array}{c}
B_{u}\left(x, y, z ; t-t_{0}\right) c_{u} \\
B_{v}\left(x, y, z ; t-t_{0}\right) c_{v} \\
B_{w}\left(x, y, z ; t-t_{0}\right) c_{w}
\end{array}\right)
$$

onde $d$ é o vetor deslocamento do ponto $(x, y, z)$, no instante $t$ com relação ao tempo $t_{0}, B$ é a matriz das derivadas parciais dos polinômios com relação às 
posições do ponto de observação (matriz configuração do modelo de deformação), e $c$ é o vetor das incógnitas dos parâmetros de deformação.

SECORD (1995) fornece os polinômios de segunda ordem, para o caso de um sistema bidimensional, com rotação $\omega$ e origem em $\left(x_{c}, y_{c}\right)$ :

$$
\begin{aligned}
& d x_{i}=a_{0}+a_{1} x_{i}+a_{2} y_{i}+a_{3} x_{i} y_{i}+a_{4} x_{i}^{2}+a_{5} y_{i}^{2}-\omega\left(y_{i}-y_{c}\right), \\
& d y_{i}=b_{0}+b_{1} x_{i}+b_{2} y_{i}+b_{3} x_{i} y_{i}+b_{4} x_{i}^{2}+b_{5} y_{i}^{2}-\omega\left(x_{i}-x_{c}\right) .
\end{aligned}
$$

Uma vez que o deslocamento de um ponto é definido pelas suas componentes nas direções dos eixos do sistema de referência utilizado, então o deslocamento deste elemento é função das coordenadas deste ponto e pode ser representado da seguinte forma, segundo BATHE (1996):

$$
\begin{aligned}
& u(x, y, z)=\alpha_{1}+\alpha_{2} x+\alpha_{3} y+\alpha_{4} z+\alpha_{5} x y+\cdots, \\
& v(x, y, z)=\beta_{1}+\beta_{2} x+\beta_{3} y+\beta_{4} z+\beta_{5} x y+\cdots, \\
& w(x, y, z)=\gamma_{1}+\gamma_{2} x+\gamma_{3} y+\gamma_{4} z+\gamma_{5} x y+\cdots .
\end{aligned}
$$

onde $\alpha_{1}, \alpha_{2}, \ldots, \beta_{1}, \beta_{2}, \ldots, \gamma_{1}, \gamma_{2}, \ldots$ são as denominadas coordenadas generalizadas. Rescrevendo na forma matricial, tem-se:

$$
u=\Phi \alpha,
$$

onde o vetor $u$ corresponde aos deslocamentos, os elementos de $\Phi$ são os coeficientes do polinômio, e $\alpha$ é o vetor das coordenadas generalizadas.

As coordenadas generalizadas são avaliadas tomando-se por base os deslocamentos de vários pontos, que podem ser obtidas pela seguinte equação:

$$
\hat{u}=A \alpha,
$$

onde $\hat{u}$ corresponde aos deslocamentos dos pontos e $A$ é a matriz configuração dos parâmetros. Se existir a inversa da matriz $A$, então tem-se:

$$
\alpha=A^{-1} \hat{u} \text {. }
$$

Com a obtenção de $\alpha$, pode-se determinar o vetor das deformações generalizadas $(\varepsilon)$ da seguinte maneira:

$$
\varepsilon=E \alpha,
$$

onde a matriz $E$ é estabelecida usando os deslocamentos da eq.(2.39).

$O$ vetor de tensão generalizada $(\tau)$ é obtido por:

$$
\tau=C \varepsilon,
$$


onde $C$ é uma matriz de elasticidade generalizada, segundo BATHE (1996).

\subsubsection{Relação com as observações}

O modelo de deformação relaciona as observações com os parâmetros de deformação. As observações estão sujeitas a erros que devem ser eliminados, ou minimizados para evitar que os mesmos sejam confundidos como deformação. Portanto, primeiramente, deve-se avaliar as observações destes possíveis erros, utilizando-se dos métodos de ajustamento de observações. Em seguida, estimam-se os parâmetros de deformação, empregando-se o princípio dos mínimos quadrados.

Os diferentes tipos de observáveis (coordenadas observadas ou derivadas, diferenças de coordenadas, ângulos, distâncias, "strains", "tilts", etc.) relacionam-se com o modelo de deformação por:

$$
l(t)=l\left(t_{0}\right)+A u,
$$

onde $l(t)$ e $l\left(t_{0}\right)$ são as observações na época $t$ e $t_{0}$, respectivamente, $A=\partial l / \partial x$, matriz configuração que relaciona as observáveis ao modelo de deformação, com $x$ sendo o vetor das coordenadas nos pontos associados com $l$, e $u$ o vetor dos deslocamentos. Assim, qualquer observação contribuirá para a determinação dos parâmetros de deformação.

Exemplos de modelos são apresentados a seguir, conforme CHEN (1983), SECORD (1985) e KUANG (1991). Se as coordenadas de um ponto são obtidas por métodos geodésicos ou fotogramétrico, as observações relacionam-se com os parâmetros, mediante o modelo de deformação, da seguinte maneira:

$$
\left(\begin{array}{l}
x_{i}(t) \\
y_{i}(t) \\
z_{i}(t)
\end{array}\right)=\left(\begin{array}{l}
x_{i}\left(t_{0}\right) \\
y_{i}\left(t_{0}\right) \\
z_{i}\left(t_{0}\right)
\end{array}\right)+\left(\begin{array}{c}
u_{i} \\
v_{i} \\
w_{i}
\end{array}\right),
$$

onde $x_{i}(t), y_{i}(t)$ e $z_{i}(t)$ são as coordenadas do ponto na época $t ; x_{i}\left(t_{0}\right), y_{i}\left(t_{0}\right)$ e $z_{i}\left(t_{0}\right)$ são as coordenadas do ponto na época $t_{0}$; e, $u_{i}, v_{i}$ e $w_{i}$ são as componentes de deslocamento do ponto com relação a um referencial cartesiano $X, Y$ e $Z$, respectivamente. As observações $l(t)$ eqüivalem às coordenadas $x_{i}(t), y_{i}(t)$ e $z_{i}(t)$, e as observações $l\left(t_{0}\right)$ às coordenadas $x_{i}\left(t_{0}\right), y_{i}\left(t_{0}\right)$ e $z_{i}\left(t_{0}\right)$. O vetor de 
deslocamentos $(u)$ constitui-se pelas componentes de deslocamento do ponto $\left(u_{i}, v_{i}, w_{i}\right)$. Para o caso de diferenças de coordenadas entre dois pontos $(i, j)$, temse:

$$
\left(\begin{array}{l}
x_{j}(t)-x_{i}(t) \\
y_{j}(t)-y_{i}(t) \\
z_{j}(t)-z_{i}(t)
\end{array}\right)=\left(\begin{array}{l}
x_{j}\left(t_{0}\right)-x_{i}\left(t_{0}\right) \\
y_{j}\left(t_{0}\right)-y_{i}\left(t_{0}\right) \\
z_{j}\left(t_{0}\right)-z_{i}\left(t_{0}\right)
\end{array}\right)+\left(\begin{array}{c}
u_{j}-u_{i} \\
v_{j}-v_{i} \\
w_{j}-w_{i}
\end{array}\right)
$$

Quando observa-se o azimute $\left(\alpha_{i j}\right)$ entre os dois pontos, tem-se:

$$
\alpha_{i j}=\alpha_{i j}\left(t_{0}\right)+\left(\begin{array}{ll}
\frac{-\cos \alpha i j}{S_{i j} \cos \beta_{i j}} & \frac{\operatorname{sen} \alpha_{i j}}{S_{i j} \cos \beta_{i j}}
\end{array}\right)\left(\begin{array}{c}
u_{j}-u_{i} \\
v_{j}-v_{i}
\end{array}\right),
$$

onde $\beta_{i j}$ e $S_{i j}$ são o ângulo vertical e a distância espacial entre os pontos, respectivamente, conforme CHEN (1983). A diferença entre dois azimutes fornece o ângulo horizontal.

Se a distância entre dois pontos é observada, então pode-se escrever a função $S_{i j}$ da seguinte forma:

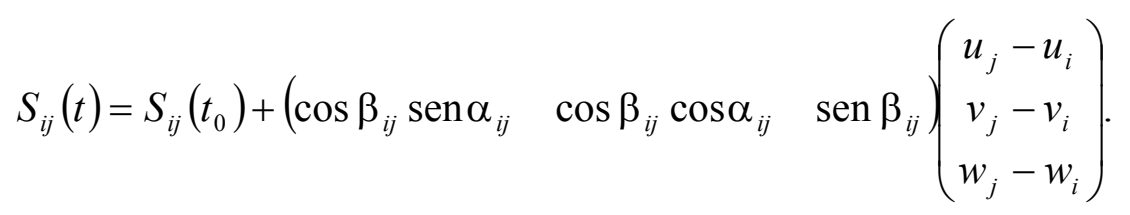

Para a observação de deformação num ponto, tem-se:

$$
\varepsilon(t)=\varepsilon\left(t_{0}\right)+c^{T} E c,
$$

onde,

$$
\begin{gathered}
c^{T}=\left(\begin{array}{ccc}
\cos \beta \operatorname{sen} \alpha & \cos \beta \cos \alpha & \operatorname{sen} \beta
\end{array}\right), \\
E=\left(\begin{array}{lll}
\frac{\partial u}{\partial x} & \frac{\partial u}{\partial y} & \frac{\partial u}{\partial z} \\
\frac{\partial v}{\partial x} & \frac{\partial v}{\partial y} & \frac{\partial v}{\partial z} \\
\frac{\partial w}{\partial x} & \frac{\partial w}{\partial y} & \frac{\partial w}{\partial z}
\end{array}\right)
\end{gathered}
$$

Quando observa-se o ângulo vertical entre dois pontos, tem-se:

$$
\beta_{i j}(t)=\beta_{i j}\left(t_{0}\right)+\left(\begin{array}{lll}
\frac{\operatorname{sen} \beta i_{i j} \operatorname{sen} \alpha_{i j}}{S_{i j}} & \frac{-\operatorname{sen} \beta_{i j} \cos \alpha_{i j}}{S_{i j}} & \frac{\cos \beta_{i j}}{S_{i j}}
\end{array}\right)\left(\begin{array}{c}
u_{j}-u_{i} \\
v_{j}-v_{i} \\
w_{j}-w_{i}
\end{array}\right) .
$$


No caso de um clinômetro horizontal, observa-se por:

$$
\tau(t)=\tau\left(t_{0}\right)+\left(\frac{\partial w}{\partial x}\right) \operatorname{sen} \alpha+\left(\frac{\partial w}{\partial y}\right) \cos \alpha,
$$

onde $\alpha$ é a orientação do clinômetro.

Nestas equações de observação, substituindo as componentes de deslocamentos pelo modelo de deformação, obtém-se as observações em funções dos parâmetros de deformação. Utilizando-se do princípio dos mínimos quadrados, pode-se determinar estes parâmetros.

\subsection{Métodos de monitoração}

CHEN (1983) classifica as técnicas de monitoração como:

a) métodos geodésicos convencionais:

- redes geodésicas de monitoração: absoluta e relativa;

- redes horizontais de monitoração: redes de triangulação, redes de trilateração e redes de triangulateração;

- movimentos verticais: nivelamento geodésico de primeira ordem.

b) método fotogramétrico:

- terrestre.

c) projetos especializados de monitoração:

- "strainmeter" mecânico (Distinvar/CERN e Distometer/Kern) e interferômetro a laser;

- medida de "tilt": nivelamento hidrostático, clinômetros eletro-mecânico e eletrolítico, alinhamento vertical (pêndulo mecânico ou prumo ótico);

- alinhamento a laser.

d)técnicas espaciais:

- VLBI - Very Long Baseline Interferometry

- GPS - Global Positioning System/Sistema de Posicionamento Global

Os instrumentos utilizados nas medições de deformação são classificados, segundo DUNNICLIFF (1988), nas seguintes categorias:

a) métodos de levantamento: elevações por nivelamento ótico; medição de distância por taqueometria; medição de uma base por teodolito e 
taqueometria; poligonação; triangulação; nivelamento a laser; medição eletrônica de distância; nivelamento trigonométrico; método fotogramétrico e GPS;

b) extensômetros;

c) clinômetros;

d) inclinômetros.

Os métodos de levantamento são usados para monitorar a magnitude e a taxa de deformações horizontais e verticais de estruturas e do terreno, DUNNICLIFF (1988). Normalmente, estes métodos são adequados para a monitoração e os instrumentos geotécnicos são requeridos somente se uma exatidão superior for exigida, ou, se os pontos a serem medidos forem inacessíveis para os métodos de levantamento. Em geral, quando os instrumentos geotécnicos (p. ex.: extensômetros, clinômetros, inclinômetros) são utilizados para monitorar deformação, os métodos de levantamento também são utilizados para relacionar as medições a um sistema de referência.

Os extensômetros são utilizados para monitorar a variação na distância entre dois pontos na superfície do terreno, numa estrutura, ou, numa escavação.

Os clinômetros são utilizados para monitorar a mudança na inclinação (rotação) de pontos no terreno ou na estrutura.

Os inclinômetros são utilizados para monitorar deformação normal a um eixo de um tubo.

Para CHRZANOWSKI \& CHEN (1990), as técnicas de monitoração de deformação classificam-se em três grupos:

a) levantamentos geodésicos (espaciais e terrestres) e medição fotogramétrica (terrestre de curto alcance);

b) técnicas geotécnicas e de engenharia estrutural: medições direta de deformações usando "strainmeters", vários tipos de extensômetros, pêndulo invertido e suspenso, "tiltmeters", inclinômetros, vários "deformeters", etc.;

c) técnicas especiais não geodésicas ("metrologia industrial”): medições interferométricas, nivelamento hidrostático, alinhamento de precisão, novos métodos holográficos, etc. 
Enquanto KUANG (1991) classifica os métodos para monitorar deformação como:

a) métodos geodésicos: métodos geodésicos terrestre [nivelamento ótico, poligonação, triangulação, medição eletrônica de distância/MED (Medidor Eletrônico de Distância), nivelamento trigonométrico] método fotogramétrico (terrestre) e técnicas espaciais (VLBI, SLR, GPS);

b) métodos não geodésicos: geotécnico (instrumentos: inclinômetros $\mathrm{e}$ extensômetros) e projetos especializados de monitoração (pêndulo invertido, níveis hidrostáticos, interferômetros a laser, equipamento de alinhamento de difração).

As categorias de dados para os esquemas de monitoração, segundo SECORD (1995), classificam-se em:

a) geodésico (ou, levantamento): observação de ângulo horizontal, ou direção, distância espacial, diferença de altitude;

b) geotécnico: similares às quantidades geodésicas, mas com extensão menor (distâncias de poucos metros, no lugar de centenas de metros).

Assim, considerando as classificações dos métodos de monitoração e os instrumentos, os dados geodésicos podem ser obtidos por:

a.1) triangulação;

a.2) trilateração;

a.3) triangulateração;

a.4) poligonação;

a.5) nivelamento geométrico;

a.6) nivelamento trigonométrico;

a.7) fotogrametria terrestre;

a.8) VLBI;

a.9) SLR;

a.10) GPS;

a.11) medida de distância por taqueometria;

a.12) medida de distância por MED.

Do mesmo modo, utilizando as classificações dos métodos de monitoração e os instrumentos, os dados geotécnicos podem ser obtidos por: 
b.1) "strainmeters";

b.2) extensômetros;

b.3) clinômetros;

b.4) inclinômetros;

b.5) pêndulo (suspenso e invertido);

b.6) alinhamento vertical (pêndulo mecânico ou prumo ótico);

b.7) alinhamento a laser;

b.8) medidas interferométricas a laser;

b.9) nivelamento hidrostático;

b.10) métodos holográficos.

\subsection{Redes geodésicas de monitoração}

Segundo CHRZANOWSKI (1981), as medições de deformação por métodos geodésicos realizam-se em dois tipos de redes: absoluta e relativa.

A configuração dos pontos está relacionada com a matriz dos coeficientes das equações de observação $(A)$, envolvendo as observações e o modelo de deformação. Deve-se encontrar a melhor configuração desta matriz para obter as precisões requeridas dos parâmetros de deformação, num modo mais econômico.

\subsubsection{Absoluta (ou, Referência)}

Este tipo de rede consiste dos pontos estabelecidos fora do corpo deformado, servindo como pontos de referência para a determinação dos deslocamentos absolutos dos pontos do objeto investigado.

Exemplo ilustrativo é mostrado na FIGURA 2.6.

O principal problema na análise geométrica de uma rede absoluta (ou, rede de referência) é a identificação dos pontos de referência estáveis. 


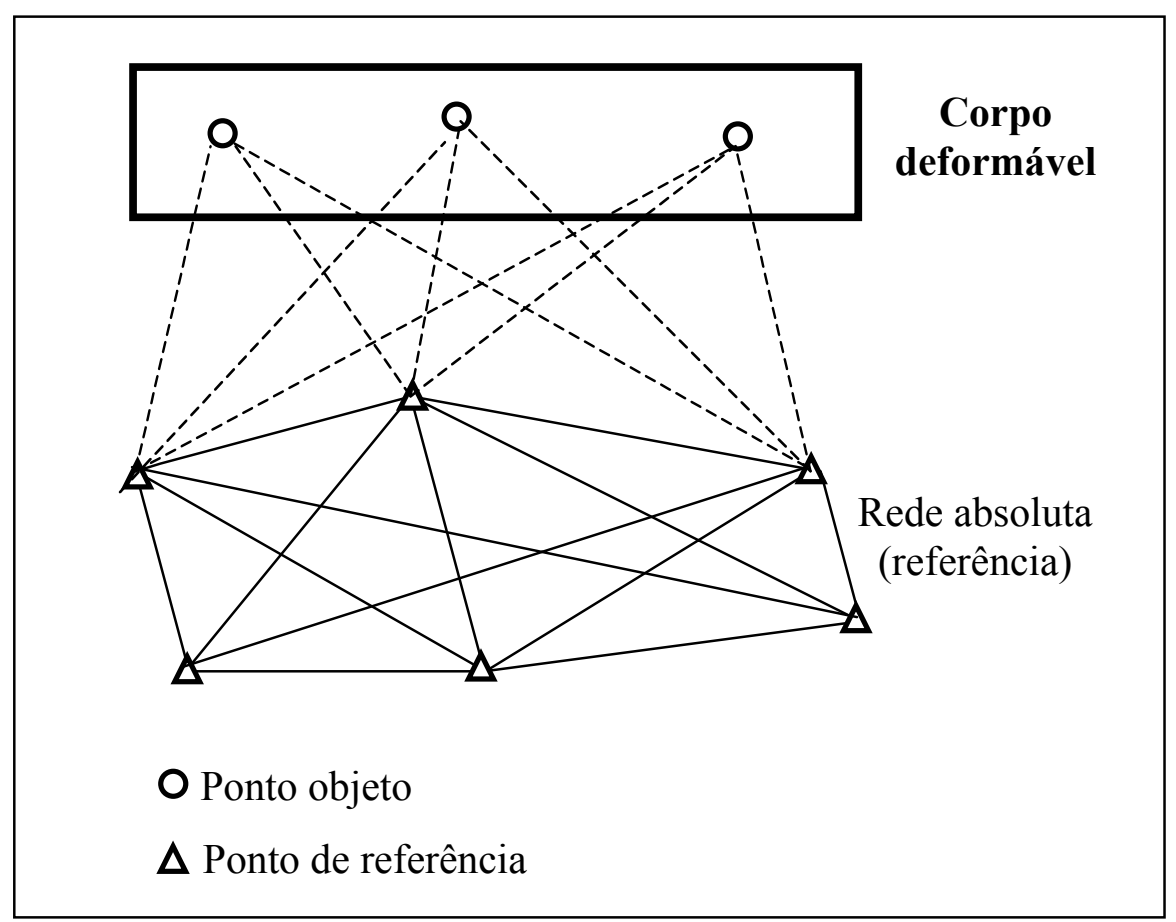

FIGURA 2.6 - Rede absoluta

\subsubsection{Relativa (ou, Objeto)}

Todos os pontos estão no objeto investigado, com a finalidade de identificar o modelo de deformação causado pelas deformações, pelos deslocamentos relativos do corpo rígido e pelos deslocamentos pontuais. Ilustração deste tipo de rede é apresentada na FIGURA 2.7. A análise de uma rede relativa (objeto) depara-se com a determinação do modelo de deformação nos domínios espacial e temporal.

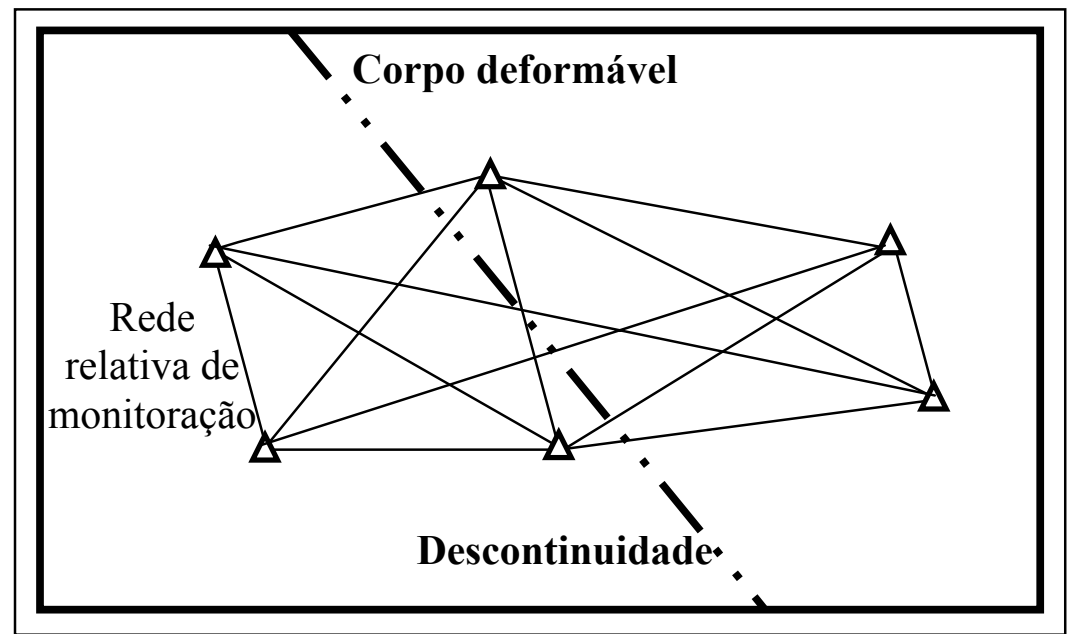

FIGURA 2.7 - Rede relativa 


\section{SISTEMA DE POSICIONAMENTO GLOBAL (GPS)}

\subsection{Introdução ao NAVSTAR GPS}

O programa NAVigation System with Timing And Ranging (NAVSTAR) Global Positioning System (GPS) é de responsabilidade do Joint Program Office (JPO) localizado na Divisão Espacial dos Sistemas de Comando da Força Aérea dos Estados Unidos (LAAFB - Los Angeles Air Force Base), Califórnia, que tem como missão adquirir e manter os serviços de posicionamento global para seus clientes. $\mathrm{O}$ diretor deste programa é responsável pelos serviços e organizações que coordenam o desenvolvimento, a aquisição e a manutenção dos recursos dos segmentos espacial, de controle e do usuário. O programa GPS de \$19 bilhões de dólares mantém a constelação de satélites e os programas de integração e instalação do Departamento de Defesa (DoD - Department of Defense), conforme LAAFB (1997a). Em setembro de 1996, o objetivo do JPO foi de estabelecer planos entre o JPO e o Departamento de Transportes (DoT - Department of Transportation) \& FAA (Federal Avionics Administration) para facilitar a união de investimento, planejamento e desenvolvimento.

O GPS foi projetado como um sistema de duplo uso com o principal propósito de aumentar a eficiência das forças militares dos Estados Unidos e de seus aliados. O GPS tornou-se rapidamente um componente integral da emergente infra-estrutura de informação global, com aplicações em mapeamento e levantamento para gerenciamento de tráfego aéreo internacional. O GPS básico é definido, segundo LAAFB (1997b), como a constelação de satélites, os sinais GPS, as estações de controle e as instalações de controle que são operadas e mantidas pelo $D o D$; o serviço de posicionamento padrão (SPS - Standard Positioning Service) como o 
serviço civil e comercial fornecido pelo GPS básico; e sistemas baseados no GPS que fornecem maior precisão em tempo real do que o SPS.

O GPS tem três principais segmentos, de acordo com LAAFB (1997c): espacial, de controle e do usuário. O GPS fornece posição (P) (tridimensional), velocidade (V) e tempo (T), ou seja, PVT, com muita exatidão e informações contínuas e em tempo real.

O segmento espacial consiste de no mínimo 24 satélites operacionais, divididos em seis planos orbitais (com no mínimo quatro satélites em cada plano). Os satélites operam em órbitas circulares com altitude aproximada de 20.200 quilômetros (10.900 milhas náutica), inclinadas de 55 graus com o plano do Equador, e com período de 12 horas siderais. Cada satélite GPS é projetado para transmitir um par de sinais de freqüência de rádio de banda $\mathrm{L}$, conhecidas como Link 1 (L1 = 1575,42 $\mathrm{MHz}$ ) e Link $2(\mathrm{~L} 2=1227,6 \mathrm{MHz})$. O sinal L1 transporta um código de precisão (P precision code) e um código grosseiro/aquisição (C/A - coarse/acquisition code), ao passo que L2 transporta somente o código de precisão (P). Os sinais são transmitidos usando técnicas de propagação, segundo LAAFB (1997a), empregando duas diferentes funções de propagação: um código C/A de 1,023 MHz somente em L1 e um código $\mathrm{P}$ de 10,23 MHz em L1 e L2. Além dos códigos, também contém as mensagens de navegação, incluindo os parâmetros de efemérides e do relógio do satélite, dados do estado do sinal do satélite e informação de sincronização do Tempo Universal Coordenado (UTC - Universal Time Coordinate).

O segmento de controle consiste de cinco estações monitoras (Hawaii, Kwajalein, Ascension Island, Diego Garcia, Colorado Springs), três antenas terrestres (Ascension Island, Diego Garcia, Kwajalein) e uma estação principal de controle (MCS - Master Control Station), localizada na base aérea de Falcon, em Colorado Springs, Colorado (EUA). As estações monitoras rastreiam passivamente todos os satélites, acumulando dados. Estas informações são processadas na $M C S$ para determinar as órbitas dos satélites e atualizar a mensagem de navegação.

O segmento do usuário consiste das antenas e receptores que fornecem posição, velocidade e tempo para o usuário. O Comando Espacial da Força Aérea dos Estados Unidos, (AFSC - Air Force Space Command) declarou a constelação de satélites GPS ter encontrado sua condição de capacidade operacional total (FOC - Full Operational 
Capability), em 27 de abril de 1995, USNO (United States Naval Observatory) (1997). As condições incluem 24 satélites operacionais (Bloco II/IIA) funcionando em suas órbitas e teste bem-sucedido para as funções operacionais militares. Para USCG (United States Coast Guard) (1997), em 17 de julho de 1995, um Office of Assistant Secretary of Defense (Public Affairs) News Release (No. 384-95) anunciou que o GPS alcançou o $F O C$, tornando-se um sistema de navegação em todo mundo para uso civil e militar.

Antes do FOC, uma capacidade operacional inicial (IOC - Initial Operational Capability) foi declarada em 08 de dezembro de 1993, USNO (1997), quando 24 satélites GPS (Bloco I e Bloco II/IIA) estavam operando em suas órbitas, disponível para uso em navegação e fornecendo os níveis do SPS. A constelação GPS, em 18 de outubro de 2000, consiste de 27 satélites do Bloco II/IIA/IIR, USNO (2000a), inclusive o satélite do Bloco II/R-5, PRN44/SVN28, lançado em 16 de julho de 2000.

O SPS é um serviço de posicionamento e tempo que está disponível para todos os usuários GPS. O SPS será fornecido na freqüência L1 do GPS que contém o código C/A e a mensagem de navegação. Segundo USNO (2000b), o SPS fornece um posicionamento com precisões de 100 metros (95\%) horizontalmente e 156 metros (95\%) verticalmente e exata transferência de tempo para UTC de 340 nanosegundos $(95 \%)$.

Além do SPS, o GPS também fornece o serviço de posicionamento preciso (PPS - Precise Positioning Service). O PPS é um serviço preciso de posicionamento, velocidade e tempo que está disponível para os usuários autorizados pelo Estados Unidos. Equipamento militar com código $\mathrm{P}(\mathrm{Y})$ fornece um posicionamento com exatidões de 22 metros (95\%) horizontalmente e 27,7 metros verticalmente e exata transferência de tempo para UTC de 200 nanosegundos (95\%), conforme USNO (2000b). O PPS é transmitido nas freqüências L1 e L2 do GPS. O PPS foi projetado especialmente para uso militar e é negado para usuários não autorizados pelo uso da criptografia do sinal.

Para questões relacionadas com a política GPS, o usuário é aconselhado a reportar-se às publicações regulares do Plano Federal de Radionavegação (FRP Federal Radionavigation Plan), preparado juntamente pelo DoD e DoT. O FRP é 
publicado a cada dois anos e é disponível pelo National Technical Information Service, Springfield, VA 22161. O FRP de 1999 pode ser acessado em USCG (2000), no seguinte endereço: http://www.navcen.uscg.mil/pubs/frp1999/FRPWord.htm. Segundo USCG (1997), uma das principais decisões é a segunda freqüência civil do GPS. Em 29 de março de 1996, o presidente dos Estados Unidos aprovou uma ampla política nacional sobre a administração e o uso futuro do GPS. Em 27 de fevereiro de 1997, o DoT e o DoD anunciaram um entendimento para assegurar aos usuários civis de GPS a disponibilidade de uma segunda freqüência. $\mathrm{O} D o D$ está de acordo em assegurar aos usuários civis o acesso ininterrupto de uma parcela do seu sinal militar, conhecido como fase da portadora, sobre a freqüência L2. Além disso, o $D o T$ e o $D o D$ concordam em desenvolver um plano para fornecer uma segunda freqüência com código C/A e mensagem de navegação para uso civil. Segundo MONICO (2000), futuramente, dois novos sinais farão parte do GPS: um sobre a portadora L2 e outro numa nova portadora (L5) com uma freqüência de 1176,45 MHz. Detalhes sobre a situação atual do posicionamento por satélite encontra-se em MONICO (2000).

Outro sistema de radionavegação baseado em satélite é o Global Navigation Satellite System (GLONASS) que foi anunciado como operacional pela Rússia em 07 de março de 1995. Este sistema permite aos seus usuários determinar posição tridimensional, velocidade e tempo em todo mundo e sob todas as condições climáticas, segundo SFCSIC (1997).

\subsection{Sinais}

Os satélites GPS transmitem as freqüências L1 e L2 moduladas por dois tipos de códigos $(\mathrm{C} / \mathrm{A}, \mathrm{P})$ e por uma mensagem de navegação. Estas freqüências derivam de uma freqüência fundamental de 10,23 MHz; a freqüência da portadora L1 é obtida do resultado da multiplicação da freqüência fundamental por 154, e a freqüência da portadora L2 por 120. Os códigos, pseudorandom noise $(P R N)$, são sequências de valores binários (zero e um, ou, +1 e -1 ) que têm características aleatórias, mas que podem ser identificados inequivocamente (SEEBER, 1993). O código C/A tem uma freqüência de 1,023 MHz, isto é, uma sequência de 1,023 milhões de dígitos binários 
ou chips por segundo (Mbps), o código P(Y) de 10,23 Mbps e a mensagem de navegação de 50 bps. C/A é usado para adquirir o código de precisão (P) e tem um período de um milesegundo (ms), enquanto o código $\mathrm{P}$ tem um período de sete dias, e é inicializado às vinte e quatro horas de sábado para domingo, criando-se assim a semana GPS. O código P tem a duração de aproximadamente 266,4 dias. O código Y é usado no lugar do código P quando o A-S (Anti-Spoofing) estiver ativado. Um código $\mathrm{W}$ é usado para criptografar o código $\mathrm{P}$ no código $\mathrm{Y}$, quando A-S estiver ativado, segundo HOFMANN-WELLENHOF et al. (1994). O A-S foi implementado em 31 de janeiro de 1994, desativado em 02 de fevereiro de 1997 e reativado em 24 de fevereiro de 1997. Além do A-S, há o SA (Selective Availability) que limita o usuário de obter toda a acurácia do sistema GPS, manipulando as mensagens de navegação (efemérides) dos dados orbitais (processo denominado de epsilon) e/ou a freqüência dos relógios dos satélites (processo dither), segundo USNO (2000b). Esta técnica, SA, que degrada o sinal GPS do usuário civil, foi implementada nos satélites do Bloco II desde 25 de março de 1990 e desativada em 01 de maio de 2000, segundo WHITEHOUSE (2000), permitindo novas aplicações com GPS.

Um estudo sobre a influência do SA no posicionamento absoluto, antes e depois de sua desativação, encontra-se em MACHADO et al. (2000). Os autores concluem que este tipo de posicionamento com código C/A, tornou-se 10 vezes mais preciso após o SA ser desativado.

\subsection{Observações}

Há dois tipos de observações GPS: pseudodistância e fase da portadora (LEICK, 1995). Pseudodistância é freqüentemente utilizada em navegação. Fase da portadora é também chamada de fase de batimento da portadora a fim de salientar o processo de medição de correlação entre a freqüência de referência da portadora que chega com a gerada pelo receptor. Em levantamentos de alta precisão deve-se utilizar a fase da portadora. Combinações de soluções de pseudodistâncias e fases da portadora estão se tornando muito comum. Embora as fases (não diferenciadas) podem ser utilizadas diretamente, tornou-se uma prática muito comum fazer várias 
combinações lineares da observação da fase portadora original, tais como dupla e tripla diferença.

Os programas comerciais, normalmente, utilizam-se destas diferenças para realizarem os processamentos de dados GPS. O programa científico GIPSY, utilizado nesta pesquisa e apresentado no item 5.2.2.2, trabalha com fases não diferenciadas, exceto para resolver ambigüidades com duplas-diferenças.

\subsection{Erros inerentes ao GPS}

As fontes de erros envolvidas neste sistema de posicionamento são aquelas relacionadas com os satélites GPS, a propagação do sinal GPS, o receptor/antena e a estação GPS que estão sendo usados no levantamento. Os efeitos que cada tipo de erro provoca nas observáveis GPS estão relacionados com os erros dos relógios, da atmosfera, das efemérides, sinais e outros, segundo MONICO (1996), e podem ser classificados como:

a) fontes de erros nos satélites GPS: erros orbitais (efemérides), erros do relógio (oscilador), efeitos relativísticos, atraso de grupo;

b) fontes de erros na propagação do sinal GPS: refração troposférica, refração inosférica, multicaminhamento de sinais, perdas de ciclos, rotação da Terra;

c) fontes de erros no receptor/antena GPS: erro do relógio, erros entre canais, centro de fase da antena;

d) fontes de erros na estação GPS: coordenadas da estação, marés terrestres, movimento do pólo, carga dos oceanos, carga da atmosfera.

Esta pesquisa trata somente dos erros do centro de fase da antena e do multicaminhamento. Os interessados nas demais fontes de erros podem recorrer à referência MONICO (1996) para maiores informações.

\subsubsection{Centro de fase da antena}

A solução de um levantamento GPS fornece o vetor entre os centros de fase das antenas utilizadas nos extremos da base observada. Para relacionar este vetor aos monumentos permanentes no terreno, a localização do centro de fase com um 
aspecto externo da estrutura da antena deve-se referir ao monumento. Como o vetor base é uma medida relativa, erros na localização do centro de fase cancelam-se quando antenas idênticas são usadas. Porém, a localização do centro de fase difere-se em cada antena, MADER \& MACKAY (1997). Assim, uma mistura de diferentes tipos e modelos de antenas requer o conhecimento das posições relativas e da localização absoluta de cada centro de fase da antena.

Os centros de fase das antenas definindo um vetor base são, atualmente, as localizações médias do centro de fase para os dados usados para produzir este vetor base. Uma antena não tem um único centro de fase bem definido. O centro de fase é uma função da direção da qual recebe um sinal. Para as antenas GPS, a variação dominante ocorre com a elevação. Conforme MADER \& MACKAY (1997), a calibração completa das antenas GPS inclui a determinação desta variação do centro de fase tão bem quanto a localização média do centro de fase.

O método preferido para calibrar antenas GPS é a câmara anecóica. Quando realizado, estas medidas fornecem as descrições precisas do centro de fase e variações com elevação e azimute. Tais medidas têm sido relatadas por SCHUPLER et al. (1994) para alguns tipos de antena. Porém, com o aumento dos tipos e modelos de antenas GPS, maneiras alternativas de calibração de antena devem ser sugeridas.

O procedimento de calibração usado por MADER \& MACKAY (1997) determina no campo a posição relativa do centro de fase e as variações da fase de um conjunto de antenas teste com relação a uma antena de referência. As características da fase da antena de referência são bem conhecidas e permite determinar as características da fase das antenas teste.

Para realizar estas calibrações de antena, MADER \& MACKAY (1997) usaram uma base teste estabelecida nas instalações de Corbin do NGS, consistindo de dois pilares estáveis de concreto de 6 polegadas de diâmetro, 1,5 metros acima do terreno e distantes 5 metros um do outro.

A variação do centro de fase, além dos erros troposférico e multicaminhamento, é o fator mais limitante para alcançar uma melhor exatidão, segundo WÜBBENA et al. (1996). As correções do centro de fase são importantes também na utilização de diferentes antenas, pois cada uma tem um padrão diferente de fase. Este aspecto torna-se mais interessante quando são estabelecidas redes 
permanentes de referência, como p. ex. a RBMC (Rede Brasileira de Monitoramento Continuo).

Nas aplicações de alta precisão com GPS, necessitam-se do conhecimento das variações milimétricas do centro de fase para corrigirem suas fontes de erros sistemáticos. Tem-se discutido diferentes maneiras para determinar as variações do centro de fase. Variações relativas do centro de fase são normalmente definidas nos procedimentos de campo, como por exemplo em MADER \& MACKAY (1997), ao passo que as variações absolutas do centro de fase são somente determinadas em calibrações em câmara anecóica, como por exemplo em SCHUPLER et al. (1994).

Por enquanto, somente calibração de campo pode determinar a diferença de variações relativa do centro de fase para um tipo particular de antena. O impacto do multicaminhamento, em geral, não é acessível e pode introduzir erros no modelo de variação do centro de fase.

Câmaras anecóicas são consideradas livres de multicaminhamento. Porém, existem discrepâncias entre padrão da câmara de teste de antena no ambiente anecóico incluindo multicaminhamento. Desde modo, deve-se reduzir o multicaminhamento, ou, seu efeito no padrão da câmara deve ser melhor entendido.

Uma antena calibrada em câmara anecóica pode ser utilizada como um antena de referência na calibração relativa de campo, permitindo, indiretamente, uma calibração absoluta .

A calibração absoluta direta no procedimento de campo ainda não foi tentada. Há dois problemas principais para calibração absoluta do centro de fase no procedimento de campo (tanto quanto na calibração relativa). Primeiramente, há a necessidade de eliminar as variações do centro de fase da antena de referência, pois o GPS é usado no modo diferencial. E, finalmente, os erros de multicaminhamento devem ser separados das variações do centro de fase. Nunca pode-se assumir um ambiente de campo livre de multicaminhamento. Por essa razão, efeitos de multicaminhamento devem ser considerados. 


\subsubsection{Multicaminhamento}

A rápida evolução das aplicações GPS tem produzido várias melhorias de performance dos receptores GPS, particularmente ao considerar a acurácia do posicionamento. Para usuários de receptores de baixo custo, os equipamentos com acuracidade horizontal de 10 a 100 metros muitas vezes satisfaz. Para usuários de receptores de alto custo para levantamentos de qualidade, podem requerer acuracidade centimétrica nas três dimensões, e em alguns casos, milimétrica. A busca por acurácias superiores tem demandado um entendimento mais profundo das fontes de erros de posicionamento GPS e como reduzi-las ou eliminá-las, WEILL (1997).

A aplicação do método diferencial reduz erros comuns do relógio do satélite (incluindo SA), da órbita e da atmosfera. Além disso, na última década, tem-se visto muito progresso em reduzir erros que ocorrem dentro do próprio receptor.

Os projetistas reconhecem agora que os esforços complementares para redução dos erros inerentes ao GPS, centralizam-se na propagação de multicaminhamento, que produz erros que não podem ser removidos por operações diferenciais. Nos últimos anos, certos grupos de usuários têm reconhecido isto como uma crucial importância para suas aplicações, segundo WEILL (1997). A propagação em multicaminhamento pode-se dividir em duas classes: estática e dinâmica. Para um receptor estacionário, a geometria de propagação muda lentamente, fazendo os parâmetros de multicaminhamento essencialmente constantes por vários minutos. Para Weill, nas aplicações móveis um receptor pode experimentar flutuações rápidas em fração de segundos.

As reduções nos erros originaram das aplicações estáticas, tais como levantamento, no qual existe maior demanda para posicionamento de alta exatidão. Estas aplicações muitas vezes experimentam um caminho secundário dominante, como por exemplo, de uma grande estrutura na vizinhança da antena. A maioria das pesquisas tem sido dentro deste contexto, embora algumas técnicas são estendidas para as situações de múltiplos caminhos secundários.

Várias técnicas de redução de multicaminhamento utilizam a geometria de propagação do sinal de um modo ou de outro. Estas técnicas incluem o uso de 
antenas especiais, tais como choke-ring, processamento espacial com arranjo de várias antenas, auxiliado pela mudança da geometria da reflexão. As técnicas tentam reduzir a intensidade dos sinais secundários enquanto preserva o sinal direto, em outras palavras, isolam o sinal direto.

Uma descrição destas técnicas é feita a seguir, WEILL (1997):

a) Antenas especiais: uma forma simples de reduzir o multicaminhamento é com o uso de um disco metálico no plano horizontal e centrado na base da antena GPS. Os descobridores desta técnica teorizaram que o disco, ou plano de terra estendido, protegeria a antena de qualquer sinal que chegasse por baixo da antena. Porém, este esquema não realizou-se tão bem quanto o esperado em razão das características das ondas eletromagnéticas. Quando a frente de onda de um sinal chega na borda do disco, proveniente de baixo, induz ondas de superfície que movimentam horizontalmente na superfície do topo do disco, que então percorrem a antena, comprometendo assim a utilidade do disco. Além disso, nem todos os sinais multicaminhamento chegam por baixo da antena, tornando este método ineficaz em tais casos. Para eliminar as ondas de superfície, o plano de terra pode ser constituído de um choke-ring, um plano de terra contendo uma série de depressões circulares de profundidade de um quarto do comprimento de onda. Estas depressões agem como linhas de transmissão encurtadas no extremo final e no seu topo exibe uma impedância muito alta na freqüência do sinal GPS. Por essa razão, as ondas superficiais não podem se formar, de maneira que a antena ganhe uma quantidade razoável de proteção ground bounce e sinais multicaminhamento que chegam de direções próximas do horizonte. A desvantagem das antenas choke-ring é que as depressões circulares conduzem a um aumento do seu tamanho, peso e custo. Mais importante ainda é que o choke-ring não pode efetivamente mitigar os sinais que chegam de cima do horizonte, que pode ser experimentado da reflexão de construções elevadas.

b) Processamento espacial de várias antenas: usuários podem também reduzir os efeitos multicaminhamento por deploying múltiplas antenas que simultaneamente recebem o sinal GPS de diferentes pontos do espaço. Por 
causa da geometria do multicaminhamento variar em diferentes locais, o sinal GPS corrompido pelo multicaminhamento geralmente terá diferentes características em cada antena. Usuários podem empregar uma forma de processar o sinal, denominada spatial processing para explorar estas diferenças e isolar o sinal direto desejado. Em alguns casos, o uso de múltiplas antenas podem ser consideradas para formar um padrão direcional da antena para o sinal direto, mas não para os sinais de multicaminhamento que chegam de outras direções.

c) Estratégia de localização de antena: usuários podem reduzir os efeitos de multicaminhamento colocando a antena em lugares menos sujeitos a receber sinais refletidos. Pode-se determinar a posição de um ponto "num lugar limpo" e calcular a posição desejada baseada nas técnicas de medição de ângulo e distância. Outro exemplo seria eliminar as reflexões do terreno com a colocação da antena do receptor no terreno, ao contrário de colocar no tripé. A situação da antena pode ser impraticável em alguns casos, mas pode ser eficaz, quando possível.

d) Observação de sinal por longo tempo: se um receptor observa um sinal por longo tempo (algumas horas), pode ter vantagens da mudança de geometria das reflexões secundárias, causadas pelo movimento angular do satélite GPS. Este movimento causa os atrasos relativos entre os caminhos de propagação principal e secundário, causando variações mensuráveis no sinal recebido. Algumas aproximações removem as componentes secundárias por identificar a variação no nível do sinal ou a razão sinalruído causada pelo reforço e cancelamento da fase alternada. Em virtude de requerer um tempo longo de observação do sinal, estas técnicas são impraticáveis para a maioria das aplicações.

Uma técnica que pode ser usada para caracterizar exatamente o multicaminhamento num local fixo, tal como numa estação base GPS, é observar os mesmos satélites entre dois dias consecutivos, observando os padrões nas medidas de pseudodistância ou da fase que são avançados por quase quatro minutos por dia em razão do período nominal do satélite de um dia sideral. 
Os métodos promissores para reduzir os efeitos de multicaminhamento utilizam processamentos de sinais em tempo real dentro do receptor. Esta nova e excitante tecnologia envolve pesquisa e desenvolvimento dos principais fabricantes de receptores que muitas vezes negociam os resultados de seus métodos sem revelar explicitamente seus segredos.

A maioria dos trabalhos publicados tratam com a medida de distância usando o código $\mathrm{C} / \mathrm{A}$, enquanto poucos trabalhos mostram claramente os efeitos do multicaminhamento nas medidas com fase da portadora. Embora alguns fabricantes de receptores tenham feito declarações incertas de performance, tem-se a impressão de que a mitigação de erros de multicaminhamento na fase da portadora apresenta problemas mais difíceis do que a pseudodistância. WEILL (1997) diz que a situação mais difícil para reduzir este erro na fase da portadora ocorre em separações pequenas, e essencialmente nenhuma mitigação é possível quando a separação é de quase um metro ou menor. Resultados na mitigação dos erros da fase da portadora são menos numerosos do que os resultados publicados com relação aos erros com código.

Sem dúvida, o progresso em mitigação de multicaminhamento tem sido significativo e continuará, conclui Weill. Em vista da disparidade entre o que é teoricamente alcançável e o que parece ser estado da arte, abre espaço para métodos mais rigorosos.

Usar multicaminhamento para detectar deformação é um método proposto por DING et al. (1999), com a vantagem de uma antena monitorar vários pontos ou uma superfície. O método consiste em diferenciar os erros de multicaminhamento antes e após a deformação da superfície investigada. Verifica, inicialmente, se a deformação é significativa ou não; em seguida, determina-se o valor da deformação se o teste de hipótese da primeira verificação for aceito. Analisando-se os resíduos dos satélites, principalmente em virtude do multicaminhamento junto ao ruído da observação, durante um período sideral, detecta-se a deformação da superfície refletora ao diferenciar os resíduos dos erros de multicaminhamento com relação ao respectivo período. As conclusões deste experimento são favoráveis à utilização dos sinais de multicaminhamento, somente na determinação de movimentos (deslocamentos) de 
uma superfície, necessitando de estudos mais detalhados para as deformações rotacionais.

Outra maneira de explorar o uso dos multicaminhamentos em monitoração de deformação, encontra-se em RADOVANOVIC (2000). Para uma mesma geometria de satélites, os multicaminhamentos repetem-se em dias siderais consecutivos, proporcionando uma correlação destes efeitos nestes dias. Esta correlação é de 85 \%, segundo RADOVANOVIC et al. (1999) apud RADOVANOVIC (2000), dependendo de quão estático é o ambiente refletor. Conhecendo as coordenadas de um ponto num dia, os erros de multicaminhamento em cada época podem ser calculados dos dados das fases coletadas. Assim, o multicaminhamento pode ser subtraído dos dados coletados nos dias subseqüentes. Radovanovic explica que embora este procedimento aumente o ruído das medidas, remove, quase que por completo, o multicaminhamento. Este método é eficiente somente em condições que deformam-se lentamente, pois o multicaminhamento descorrelaciona-se espacialmente, conforme RADOVANOVIC (2000). Além disto, o método requer que o ambiente da antena seja estático, pois o multicaminhamento depende da reflexibilidade dos refletores de sinais e da geometria entre satélite e antena. Ambas exigências são encontradas na maioria das situações relacionadas com monitoração de deformação, menciona Radovanovic. Nos experimentos realizados por Radovanovic, obteve-se acuracidade de $5 \mathrm{~mm}$ com a técnica de mitigação de multicaminhamento época a época. 


\section{SISTEMAS}

Neste capítulo, apresenta-se uma revisão bibliográfica de sistemas, métodos e programas para monitorar deformação.

\subsection{O sistema CDMS}

O sistema CDMS foi desenvolvido pelos engenheiros do exército dos Estados Unidos da América (USACE - U. S. Army Corps of Engineers) para monitorar deformação (CDMS - Continuous Deformation Monitoring System), iniciou-se em 1985 de maneira inteiramente automatizada, segundo FRODGE (1992). O sistema utiliza-se do GPS para levantamento de deformação e foi projetado para qualquer tipo de estrutura, p. ex.: barragem (sem auxílio de operador). LYTLE (1982) apresenta o sistema desenvolvido pelo USACE para o distrito de St. Louis, no estado de Illinois, EUA, tratando da aquisição, do processamento e da representação dos dados. LOGAN (1988) exemplifica a aplicação do programa pelos engenheiros dos laboratórios de Topografia do exército dos EUA (USAETL - U. S. Army Engineer Topographic Laboratories), na barragem de Uniontown, localizada no distrito de Louisville, no estado da Virginia, EUA, concluindo que os métodos de alinhamento ótico e nivelamento consomem dez dias de trabalho, enquanto o GPS determina todos os 110 pontos, no modo cinemático relativo, em dois dias. A vantagem do uso do GPS neste projeto relaciona-se com o problema de intervisibilidade exigida nos métodos convencionais.

DELOACH (1989) apresenta o sistema contínuo de monitoração (CMS Continuous Monitoring System) do USACE para estudos de deformação estrutural com a tecnologia GPS. Em 1989, o CDMS foi instalado na barragem de Dworshak, uma barragem de gravidade de concreto, com 200 metros de altura, no Rio 
Clearwater, próximo de Orofino, Idaho, EUA. Durante três meses de demonstração nesta barragem, realizaram levantamentos diários de deformações, utilizando quatro estações de monitoração localizadas na respectiva estrutura. Os resultados obtidos com o CDMS registraram precisões de 3 milímetros, horizontalmente e verticalmente, para bases de 300 metros. Os movimentos foram verificados, independentemente, com instrumentos óticos.

\subsection{O sistema LOCAL}

Este sistema analisa, ajusta, otimiza e representa graficamente as redes geodésicas, segundo GRÜNDIG et al. (1985), permitindo a análise de deformação de redes uni, bi e tridimensional. A análise requer os resultados dos ajustamentos da rede em todas as épocas. Uma aplicação para análise geométrica de deformação realizou-se numa rede ao sul da Alemanha, com propósito de detectar deslizamentos numa área onde construía-se uma estrada. Outro exemplo prático foi na rede Hollister, próximo da falha de San Andreas, Calaveras, e Sargent no oeste dos EUA, para detectar movimentos da crosta.

O sistema LOCAL utiliza módulos para acessar os dados e armazenar os resultados para uso posterior em outros componentes. Os resultados dos ajustamentos de observações de cada época são gerados e armazenados num arquivo de gerenciamento de dados. Exemplos destes resultados são: tipo de rede; época; número de variáveis; soma dos quadrados dos resíduos; variância a priori de cada época; matriz variância-covariância de cada época; número e tipo de observações. Com as informações de uma posição entre épocas diferentes, gera uma época combinada e armazena o resultado num arquivo. Assim, comparação multi épocas pode repetir, comparando e testando as deformações entre duas épocas. Para comparar as posições entre as épocas investigadas, as coordenadas devem referir a um único sistema de referência; caso contrário, obtém-se conclusões errôneas em virtude das posições serem dependentes do sistema de referência. O LOCAL possui um módulo para realizar a transformação entre diferentes sistemas.

A análise geométrica das posições entre várias épocas consiste do teste global, no qual a hipótese nula estabelece que nenhum movimento significativo ocorre entre 
as épocas observadas. Ao detectar movimentos, realiza-se o teste local para verificar quais pontos (ou, grupos de pontos) tiveram suas posições alteradas.

As conclusões sobre as aplicações do LOCAL são de que o sistema é capaz de obter as exigências impostas.

\subsection{O método UNB DEFNAN}

CHRZANOWSKI et al. (1986) descrevem o método UNB DEFNAN que trata da análise geométrica de levantamentos de deformação. Um corpo tem sua deformação descrita no espaço tridimensional por nove parâmetros (seis componentes de deformação e três componentes de rotação), em cada ponto. Estes parâmetros são obtidos pela relação deformação-deslocamento, se a função deslocamento representando o corpo é conhecida. CHRZANOWSKI et al. (1986) desenvolveram um método generalizado para encontrar a melhor função deslocamento.

Assim, todos os parâmetros de deformação (componentes de deformação, de rotação e do corpo rígido), para qualquer ponto do corpo deformador, são determinados com relação às funções deslocamentos utilizadas na análise do método generalizado da Universidade de New Brunswick (UNB - University of New Brunswick), no Canadá.

A análise de deformação realizada com este método consiste das seguintes fases, segundo CHEN (1983), SECORD (1985) e CHRZANOWSKI et al. (1991):

i) avaliação das observações e da tendência de deformação;

ii)análise global da tendência de deformação nos domínios do espaço e do tempo, e seleção dos modelos de deformação;

iii) ajustamento dos mínimos quadrados do(s) modelo(s);

iv) seleção do melhor modelo;

v)representação gráfica do deslocamento e da deformação.

SECORD (1995) apresenta este método com nove fases:

a) projeto do esquema de monitoração;

b)estabelecimento das variâncias e possíveis correlações entre as observações numa única campanha, ou, entre campanhas; 
c) detecção de erros sistemáticos e grosseiros;

d)tendência espacial e/ou temporal;

e) seleção de possíveis modelos de deformação;

f) estimação dos parâmetros dos possíveis modelos;

g)avaliação dos modelos e escolha do melhor modelo;

h)cálculo das características de deformação (p. ex.: deslocamento, deformação);

i) representação gráfica da deformação.

O método desenvolvido pela UNB tem-se aplicado em: projetos industriais e científicos, incluindo estudos de subsidência em campos petrolíferos e áreas de mineração; análise de deformação de barragens; monitoração de estabilidade de declives em áreas de mineração; investigação de deformação de túneis e movimentos tectônicos, CHRZANOWSKI et al. (1991).

Um diagrama adaptado do programa UNB DEFNAN é apresentado na FIGURA 4.1.

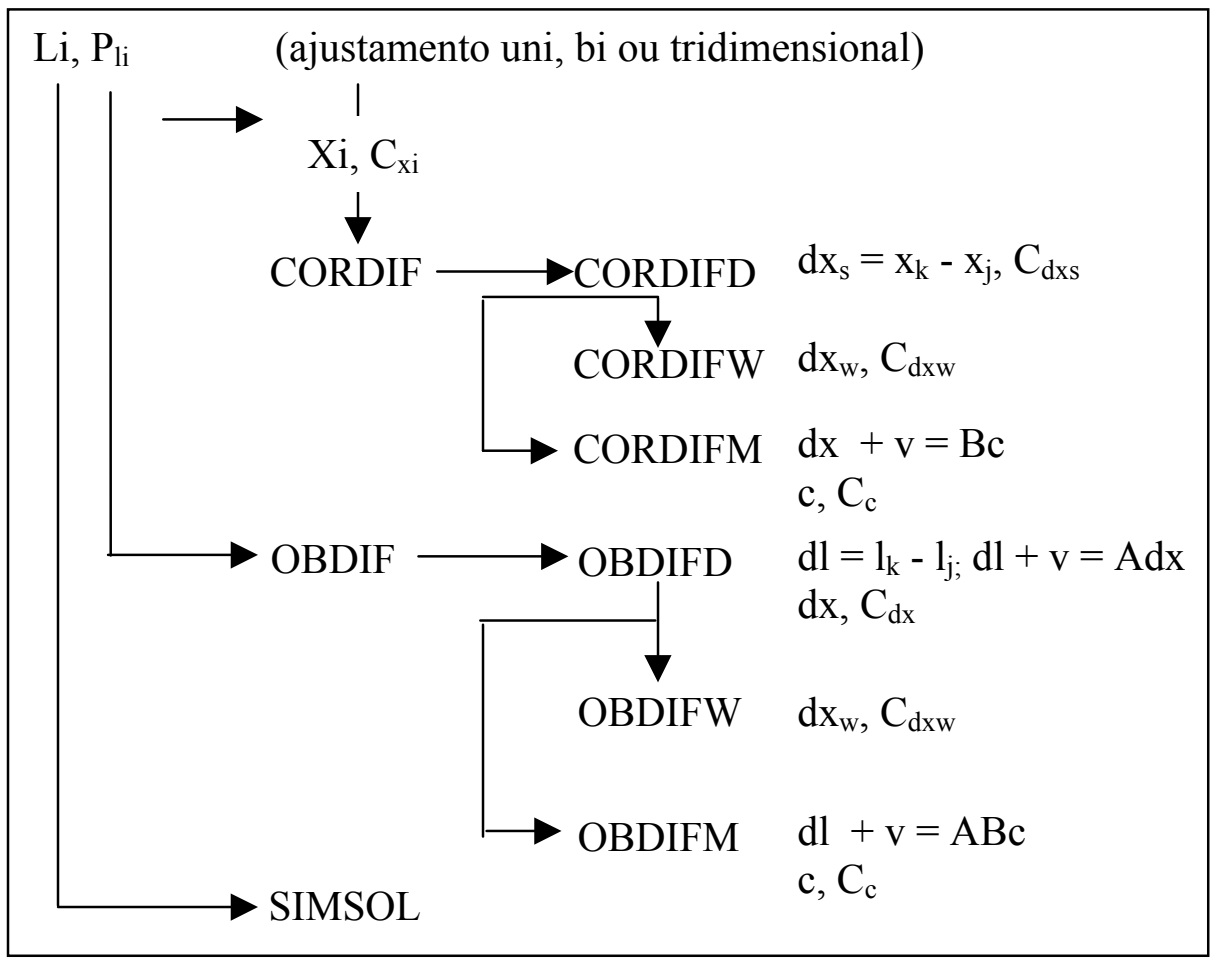

FIGURA 4.1 - Diagrama do método UNB DEFNAN (Adaptado de:

CHRZANOWSKI et al., 1991) 


\subsection{O programa PANDA}

O programa PANDA aplica-se na prática de levantamento, segundo NIEMEIER \& TENGEN (1988), tais como: planejamento e otimização de projeto; ajustamento e análise de qualidade de redes; e na determinação de movimentos após duas épocas medidas. O PANDA consiste de três programas principais:

i) PAN: para ajustamento de redes;

ii)DEFANA : para análise de deformação;

iii)PANPL: para representação gráfica dos resultados.

Exemplos das aplicações, conforme NIEMEIER \& TENGEN (1988), são:

- pré-análise eotimização de rede de túneis;

- ajustamentoeanálise de rede real de uma barragem;

- ajustamentocombinado de GPS e observações terrestres;

- análise de deformação para duas épocas da rede de uma barragem.

Esquemas dos programas PAN e DEFANA do PANDA são apresentados nas FIGURAS 4.2 e 4.3 .

Observações:

- Direções/ângulos

- Distâncias

- Azimutes

- Coordenadas
Parâmetros de ajustamento:

- Datum: livre, fixo, fraco

- Parâmetros adicionais

- Simulação ou observações reais

Ajustamento:

-Parâmetros estimados $\hat{X}$

-Matriz cofatora $\mathrm{Q}_{\mathrm{x}_{1}}$

-Fator de variância $\hat{\sigma}_{0_{1}}^{2}$

Análise:

- Precisão

- Confiabilidade

- Outlier

- Variância

- Parâmetros adicionais

FIGURA 4.2 - Programa PAN do PANDA (Adaptado de: NIEMEIER \& TENGEN, 1988) 


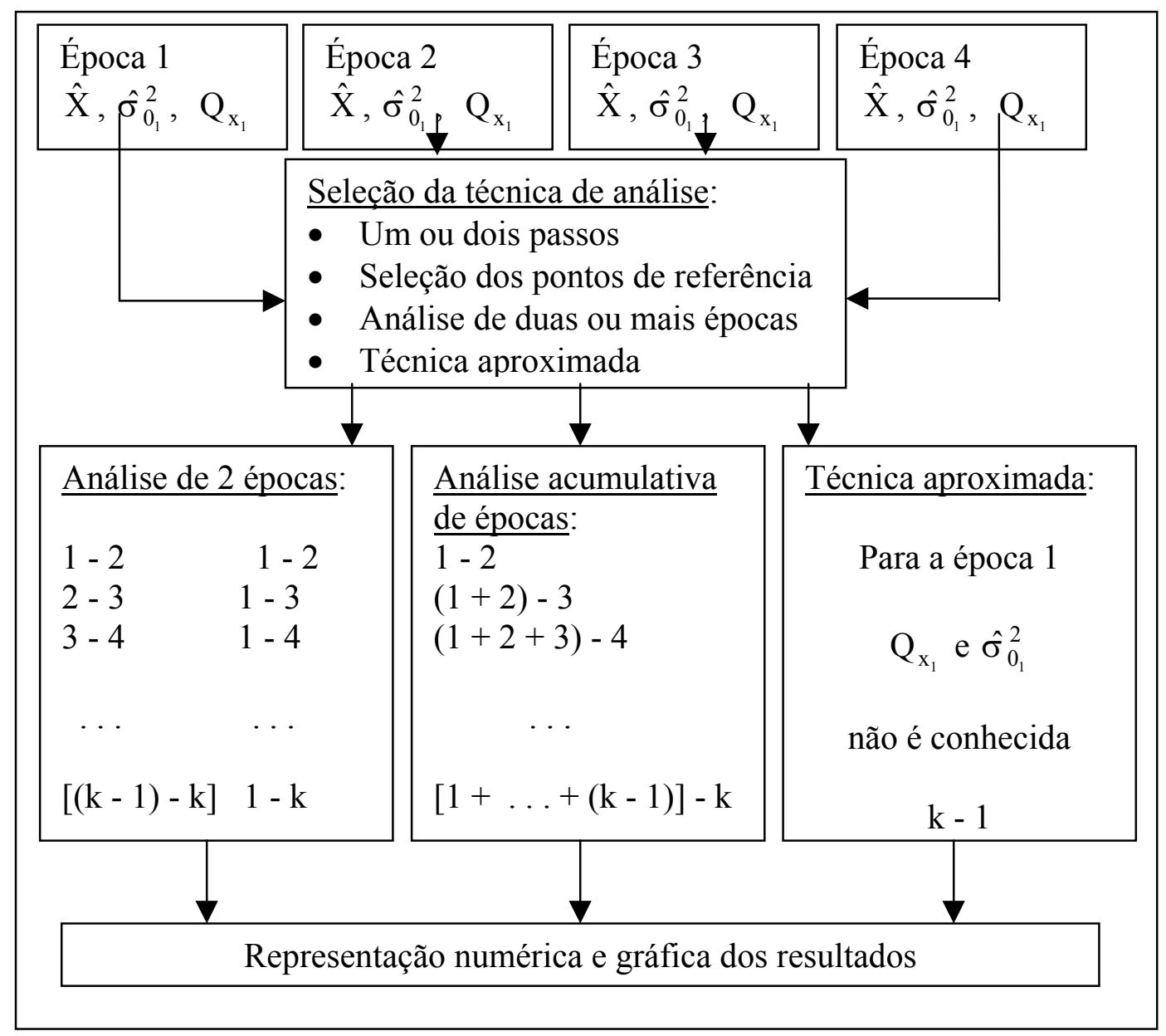

FIGURA 4.3 - Programa DEFANA do PANDA (Adaptado de: NIEMEIER \&

TENGEN, 1988)

\subsection{O sistema BOCK \& SHIMADA}

BOCK \& SHIMADA (1989) apresentam um sistema que monitora continuamente a crosta terrestre e estruturas artificiais, utilizando-se de redes GPS. Técnicas geodésicas espaciais, em particular o GPS, contribuirão com dados valiosos para diminuir os perigos naturais. A monitoração contínua com GPS permitirá caracterizar e entender a distribuição espacial e temporal da deformação dentro de regiões, das quais injunções físicas do processo do fenômeno pode ser deduzido. Para Bock e Shimada, as medições contínuas com GPS são métodos de baixo custo para monitorar grandes estruturas, enquanto os métodos geodésicos convencionais para monitorar deformação são trabalhosos e onerosos. O principal desafio é analisar e interpretar corretamente os dados coletados, num tempo adequado, para distinguir 
entre deformação e ruído da medição. BOCK \& SHIMADA (1989) denominam as componentes de um sistema de monitoração como:

i) sistema de campo: constitui-se das estações GPS e das estações fiduciais;

ii) sistema de controle: obtém automaticamente os dados, analisa os dados GPS, realiza uma análise de deformação, gerencia o banco de dados, armazena e divulga os dados para os usuários.

O sistema também utiliza-se de conexões para troca de comunicações entre as estações. Uma representação deste sistema, conforme BOCK \& SHIMADA (1989), apresenta-se na FIGURA 4.4. O desafio, segundo Bock e Shimada, é coletar, processar, compreender, arquivar e determinar grandes volumes de dados, e acompanhar estas tarefas de maneira eficiente e rápida.

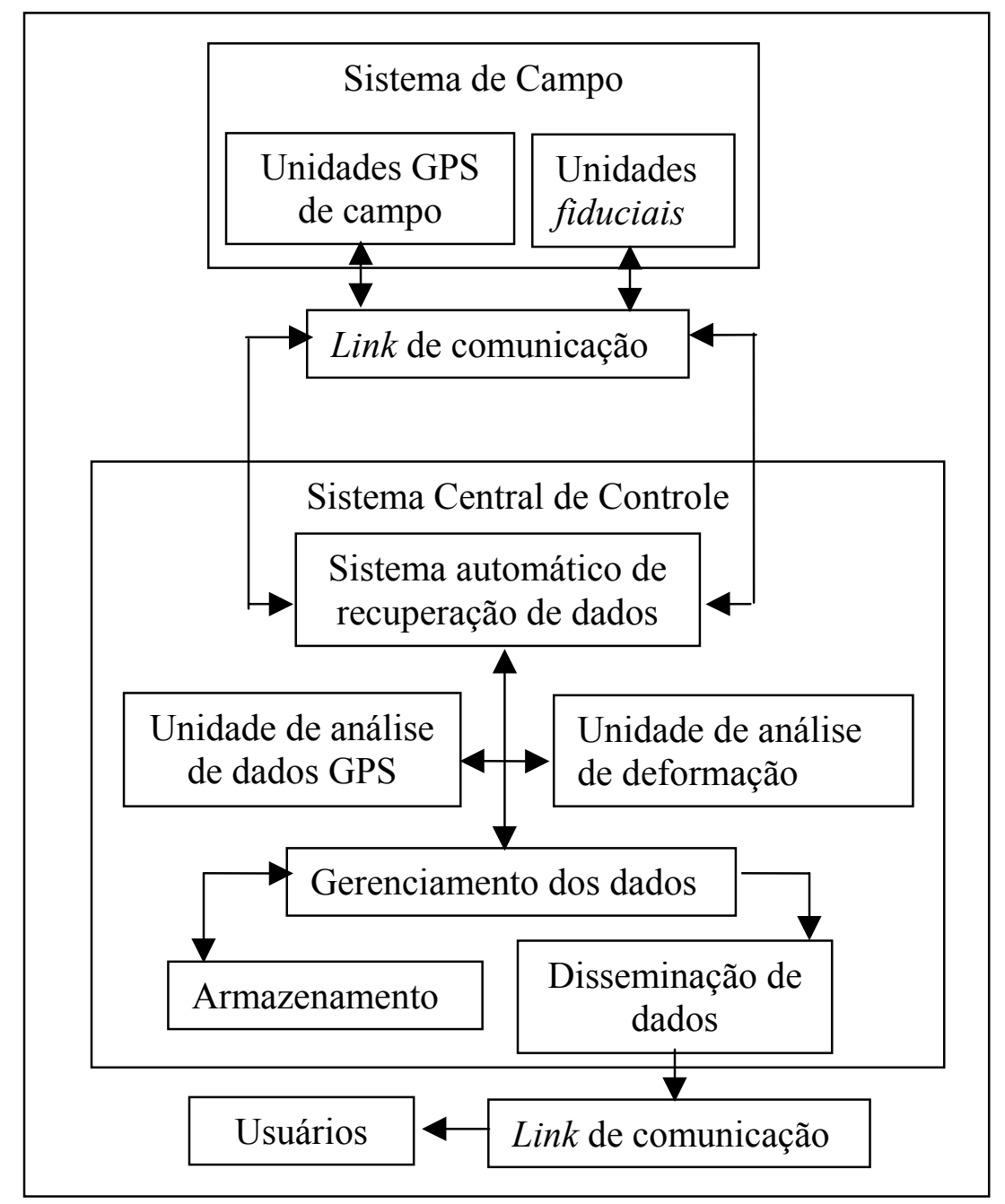

FIGURA 4.4 - Componentes de um sistema de monitoração (Adaptado de: BOCK \& SHIMADA, 1989) 


\subsection{O sistema CASDEF}

O sistema CASDEF calcula o movimento tridimensional e os erros para cada estação numa rede de monitoração, segundo MCLELLAN et al. (1989). Também se utiliza das medidas de rotação para reduzir as coordenadas ao centro da obra investigada (p. ex.: uma tubulação), e separar os deslocamentos e as rotações. Este sistema fornece um método rápido e preciso de determinar movimentos 3-D de uma estrutura. Os resultados obtidos são de exatidão subcentimétrica e adequados para a maioria dos projetos de detecção de deformação. Segundo os autores, o GPS foi capaz de fornecer posicionamento e análise de deformação com exatidão de poucos centímetros em todas as três direções. Para obter estes resultados, pré-análise e design de redes devem ser usados. Informações geotécnicas são necessárias para identificar áreas de instabilidade. Áreas estáveis, nas quais nenhum movimento é esperado, são ótimas localizações para as estações da rede principal. Estas estações são pontos e com base nestes, todos os movimentos absolutos serão referenciados. Áreas dinâmicas ou instáveis são monumentadas com o propósito de detectar e quantificar a magnitude e direção do movimento. No caso de deformação, movimentos são determinados de uma época em relação a outra. Se observações convencionais são utilizadas para verificar ou suplementar os dados GPS, intervisibilidade entre os monumentos e geometria da rede devem ser considerados.

O programa possibilita detectar movimentos com uma específica confiabilidade estatística. Os movimentos são matematicamente expressos por diferenças de coordenadas e propagação de covariância, as quais são obtidas dos programas CASP, RAPP e CASPER.

O programa CASP gera arquivos com resultados dos processamentos dos dados GPS, p. ex.: com o programa TRIMVEC (TRIMBLE). Estes arquivos contém as diferenças de coordenadas e informações da covariância, compatíveis com os programas RAPP e CASPER.

O programa RAPP determina as ondulações geoidais em cada estação, enquanto o CASPER realiza o ajustamento tridimensional pelo método dos mínimos quadrados. Um fluxograma contendo estes programas é apresentado na FIGURA 4.5. 


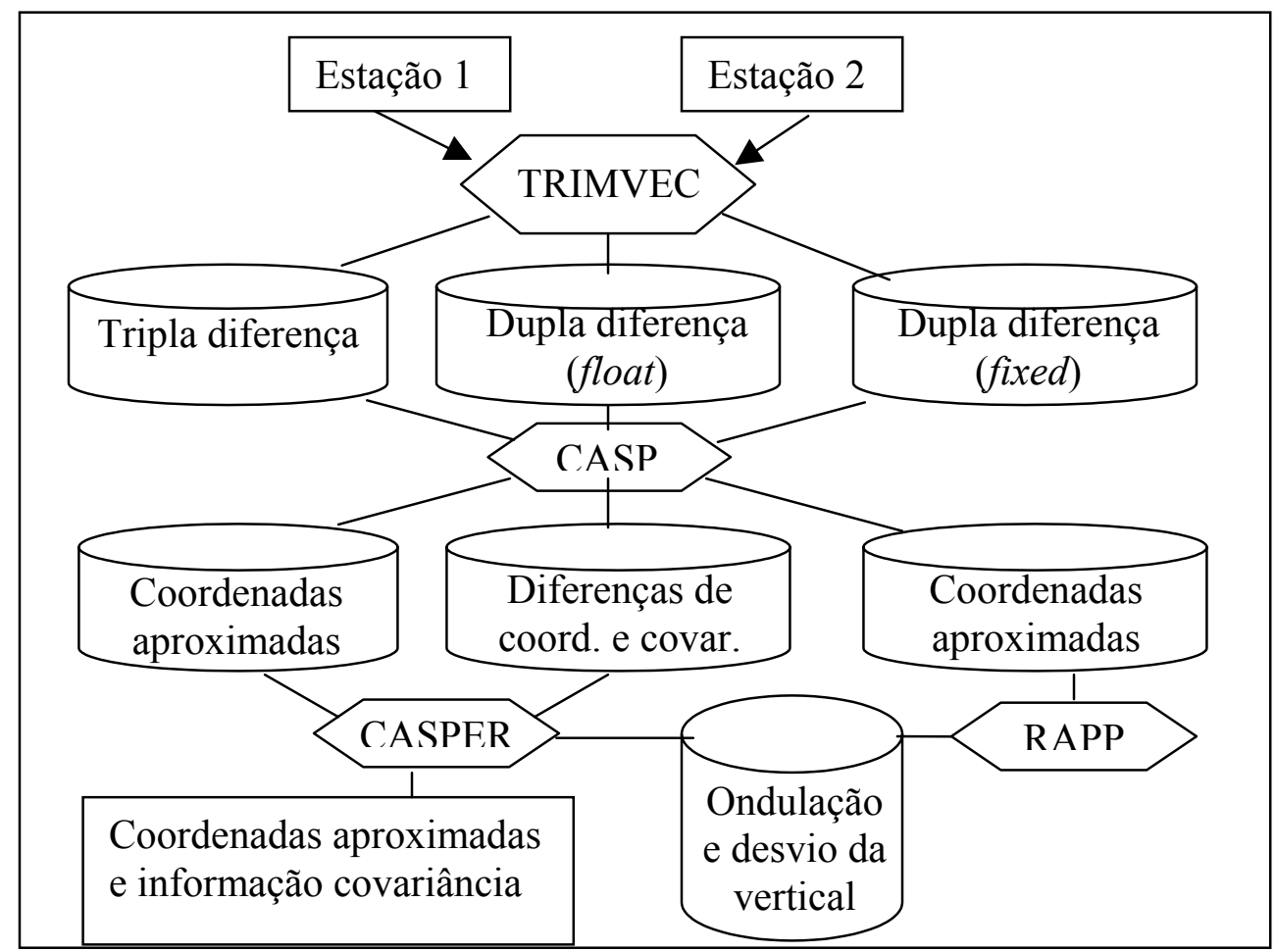

FIGURA 4.5 - Fluxograma contendo os programas CASP, RAPP e CASPER (Adaptado de: MCLELLAN et al., 1989)

\subsection{O sistema CANADAS}

O sistema de análise de deformação auxiliado por rede de computador, CANADAS (Computer Aided Network Aided Deformation Analysis System), realiza o ajustamento de redes de levantamentos (uni, bi e tridimensional) e faz a análise geométrica de deformação, TESKEY \& BIACS (1991).

CANADAS consiste de dois programas: MONALYSA e GEODEAN. O primeiro analisa e ajusta a rede de monitoração (MONALYSA - Monitoring Network Analysis and Adjustment), enquanto o outro realiza a análise geométrica de deformação (GEODEAN - Geometric Deformation Analysis), ou seja, analisa-se os deslocamentos entre as épocas da monitoração de deformação.

Fluxogramas destes programas, MONALYSA e GEODEAN, são apresentados nas FIGURAS 4.6 e 4.7. Segundo LOVSE et al. (1995), o comportamento dinâmico de deformação de estruturas de engenharia tem sido assunto de interesse para engenheiros por muitos anos. 


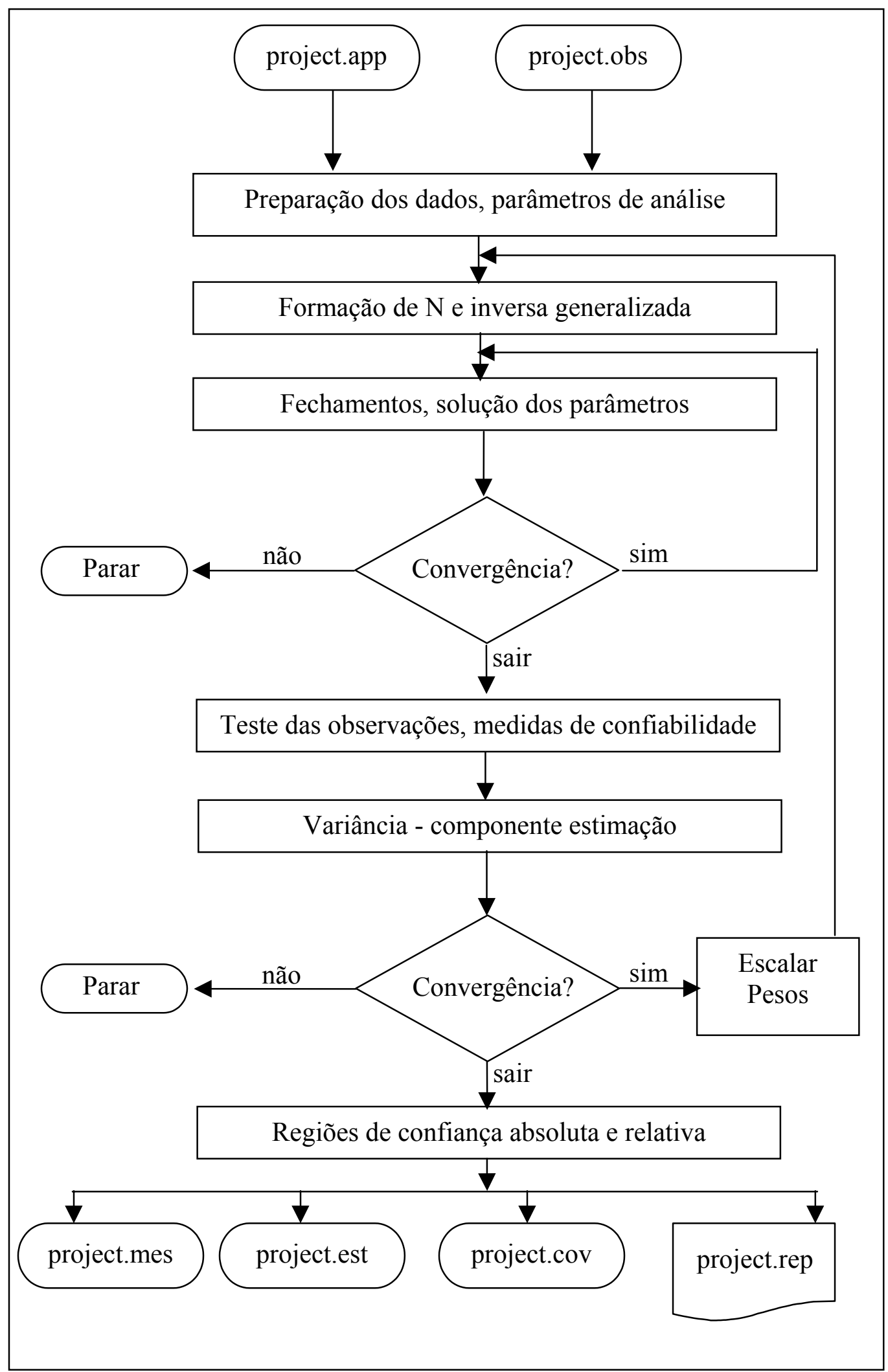

FIGURA 4.6 - Fluxograma do programa MONALYSA do CANADAS (Adaptado de: TESKEY \& BIACS, 1991) 


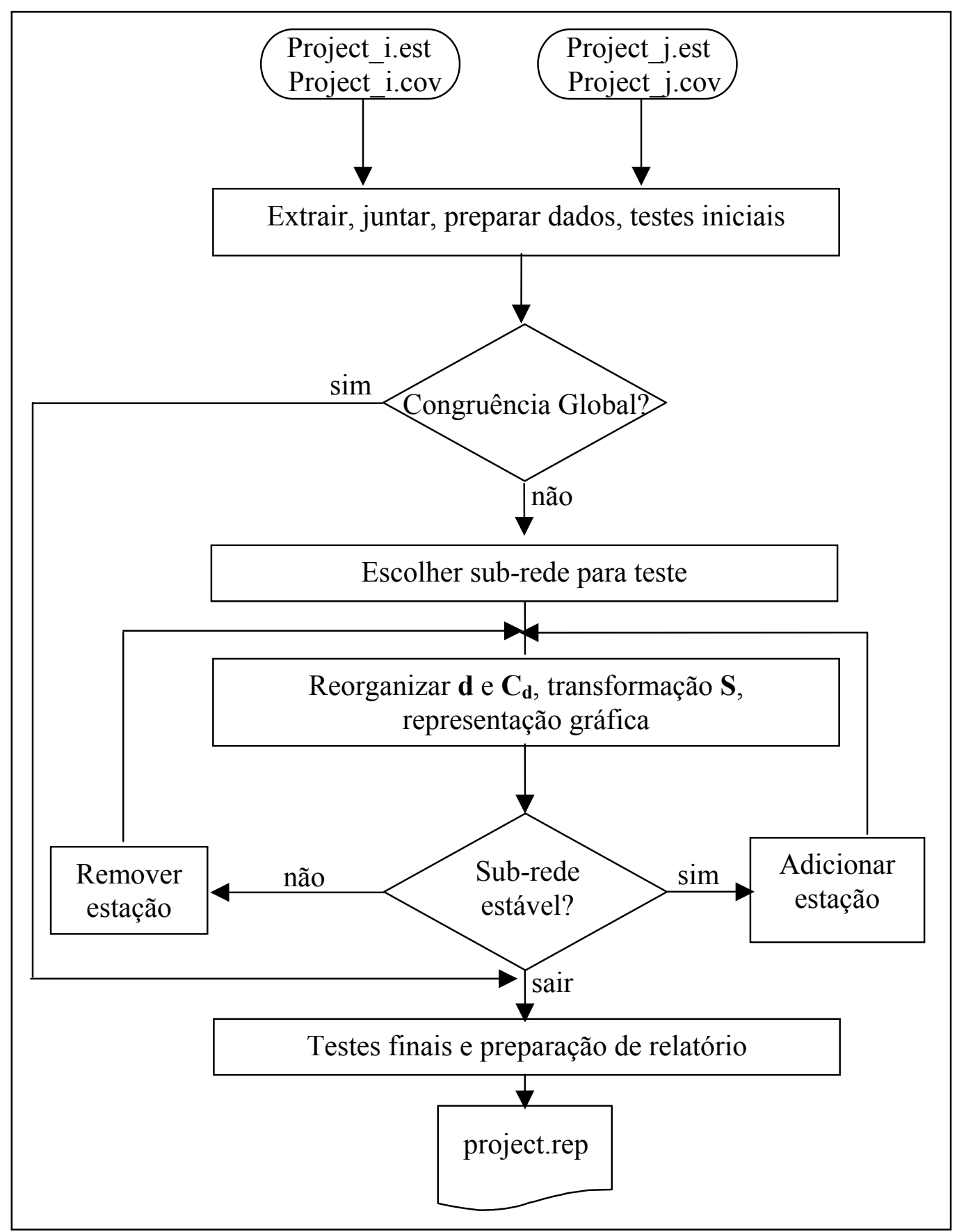

FIGURA 4.7 - Fluxograma do programa GEODEAN do CANADAS (Adaptado de:

TESKEY \& BIACS, 1991)

Alguns exemplos de comportamentos em estruturas de engenharia analisados são: vibração em estruturas, tais como grandes pontes, torres e grandes construções; movimentos causados por mudanças de temperatura ou forças de operação das máquinas; movimentos acelerados causando, imediatamente, falhas de estruturas 
geotécnicas, tais como declives em áreas de mineração. Uma aplicação específica tratada em LOVSE et al. (1995), refere-se às vibrações estruturais da Torre de Calgary, em Alberta, Canadá, usando o GPS no modo diferencial.

\subsection{O sistema HEIN \& RIEDL}

O sistema HEIN \& RIEDL é adequado para pesquisas de terremotos, erupções vulcânicas, além de monitorar deformações de objetos de engenharia, conforme HEIN \& RIEDL (1995). O sistema obtém observações de satélites GPS e determina as posições das antenas com uma freqüência de $20 \mathrm{~Hz}$. Os receptores GPS utilizados neste sistema contém somente uma freqüência, portanto de custo muito baixo, e com raio de aplicação limitado a distâncias menores do que 07 - $10 \mathrm{~km}$ entre a estação de referência e a estação monitora. Assim, o sistema consiste das seguintes partes:

a) estação de referência: responsável pela aquisição e pelo armazenamento dos dados recebidos da rede GPS, pelo cálculo das posições e pela representação dos resultados obtidos;

b)estações de monitoração: constituem a rede GPS e transmitem os dados obtidos à estação de referência.

Cada estação deste sistema possui uma antena de telemetria para comunicação. Portanto, os dados obtidos pelas estações de monitoração são transmitidos à estação de referência, na qual analisam-se os dados e visualizam-se os resultados. Uma ilustração deste sistema encontra-se em HEIN \& RIEDL (1995), na FIGURA 4.8.

Hein e Riedl concluem que o sistema de monitoração de deformação em tempo

real, baseado no modo diferencial GPS, ou seja, no DGPS (Diferential GPS), e possivelmente o GLONASS, é adequado para pesquisas referentes a desastres. Além disso, o protótipo deste sistema com GPS mostrou que é possível monitorar variação de posição no nível do milímetro, com freqüência de 1 a $20 \mathrm{~Hz}$. O sistema possibilita novas pesquisas em Geofísica, com relação ao comportamento de curto prazo, p. ex.: erupções vulcânicas e terremotos, além de fornecer uma análise econômica de deformação em tempo real. 


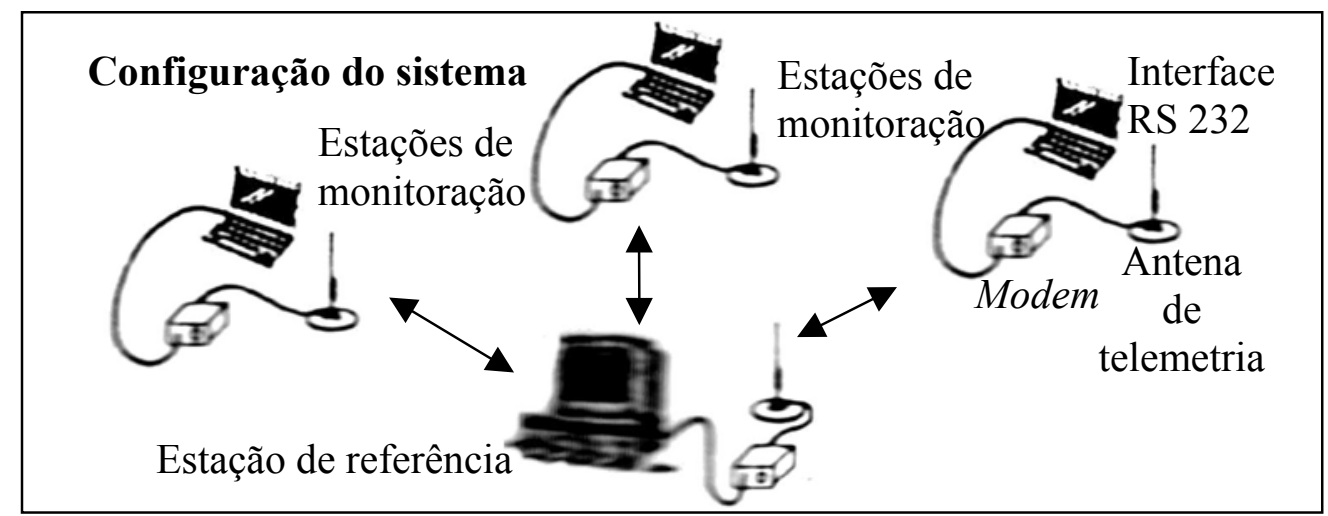

FIGURA 4.8 - Configuração do sistema HEIN \& RIEDL (Adaptado de: HEIN \&

$$
\text { RIEDL, 1995) }
$$

\subsection{O sistema DAMADA}

Este sistema gerencia os dados utilizados na análise de deformação, e possibilita uma coleta de dados mais eficiente, com menos erros e com mais consistência nas verificações, uma redução no número de funcionários, e a realização do processamento e da representação gráfica, de acordo com SECORD (1995).

O gerenciamento de dados para análise de deformação (DAMADA - DAta MAnagement for Deformation Analysis) também permite a conversão de um sistema manual para a automação da obtenção, do processamento e da análise dos dados, e da representação gráfica da deformação. A FIGURA 4.9 ilustra este sistema.

De acordo com Secord, o processo de monitoração possui cinco estágios: o planejamento do esquema; a coleta e o processamento dos dados; a análise de tendência; a modelagem da deformação; e o melhoramento do esquema. Cada fase relaciona com as outras, de maneira que a alteração em alguma deve ser considerada nas demais.

Secord desenvolveu o DAMADA em virtude da necessidade de um sistema de gerenciamento de dados que acomodasse uma variedade de níveis de automação. Esta demanda originou da Estação de Geração de Mactaquac, de New Brunswick, localizada a $16 \mathrm{~km}$ de Fredericton, Canadá. A estação consiste de uma barragem de concreto, com $518 \mathrm{~m}$ de comprimento e $46 \mathrm{~m}$ de altura. 


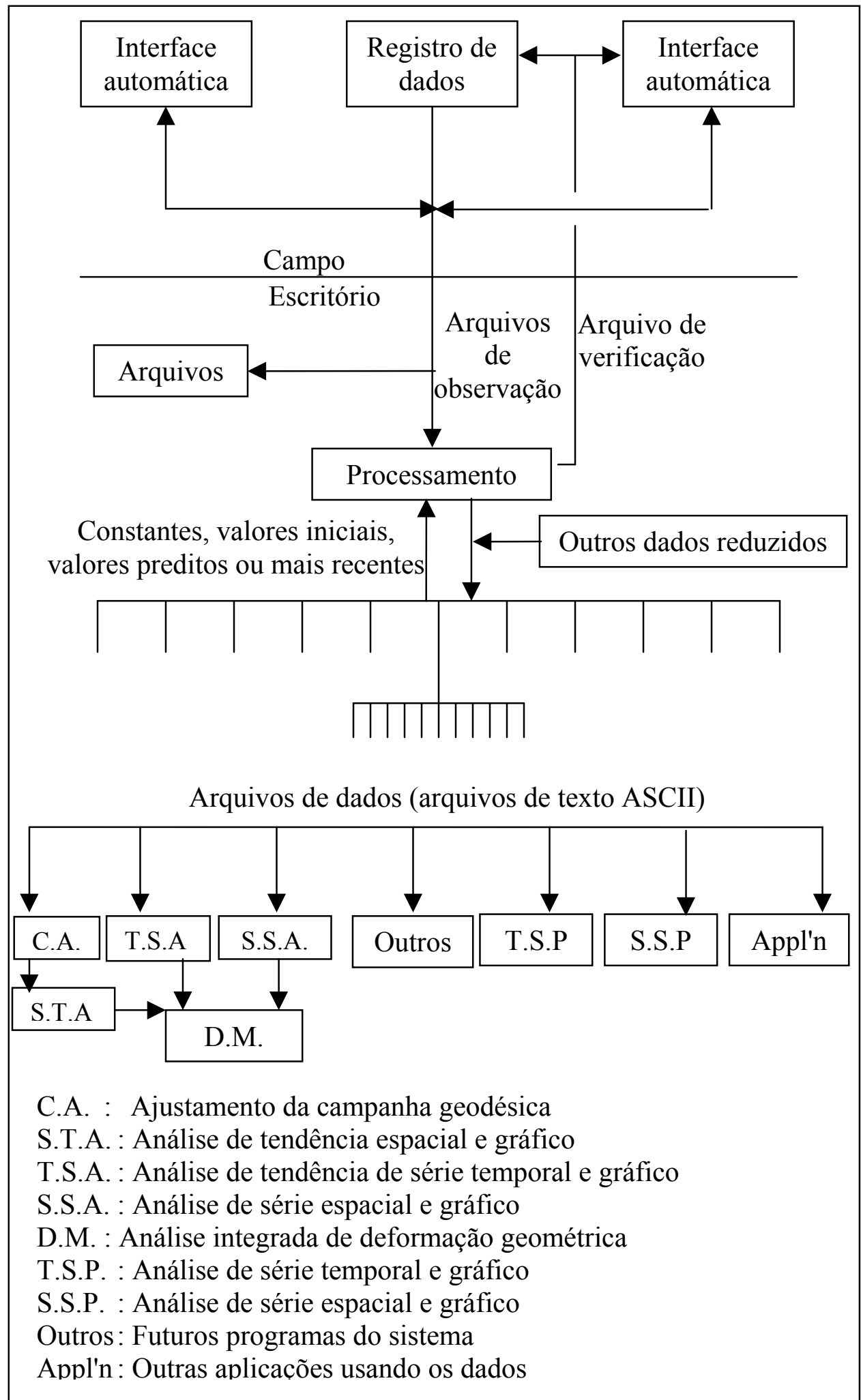

FIGURA 4.9 - O sistema DAMADA (Adaptado de: SECORD, 1995) 


\subsection{Outros}

MONICO (1988) elabora quatro programas em linguagem Fortran: o primeiro trata do modelo paramétrico multivariado, onde testes de hipóteses são tratados como injunções; o segundo realiza o ajustamento clássico; os outros dois apresentam o ajustamento livre com pseudo-inversa e I. G. R. S. (Inversa Generalizada Reflexiva Simétrica), respectivamente. Um dos objetivos do trabalho de Monico é verificar qual ajustamento (clássico ou livre) apresenta melhores resultados na detecção de deslocamentos. Monico utilizou três tipos de redes de nivelamento, simuladas, nas quais os deslocamentos são conhecidos.

SILVA (1992) apresenta um pacote de programa para ajustamento e análise de deformação de redes geodésicas de monitoração, cujas observações podem ser ângulos, distâncias, posições e azimutes, e combinações com vetores GPS. Para estas combinações entre dados terrestres e GPS, SILVA (1993, 1997) implementou o programa rede terrestre e GPS (TAGNET - Terrestrial And Gps NETwork).

Os fatores responsáveis pela crescente utilização de redes GPS para monitoração contínua são a capacidade operacional total FOC do sistema GPS e a diminuição no preço e no tamanho dos receptores, ROBERTS \& RIZOS (1997). Para estes pesquisadores, desenvolver um sistema automático de rede GPS para monitorar aplicações em escala pequena é um desafio para a engenharia e para a programação. Também citam como aplicações de rede GPS contínua em escala grande, a rede GSI no Japão, a rede GPS integrada no sudeste da Califórnia, EUA, (SCIGN - Southern California Integrated GPS Network) e a rede SWEPOS, na Suécia para monitorar movimentos da crosta em tempo quase real. Para rede GPS em escala menor, exemplificam com os sistemas GPS contínuos para monitorar vulcões, como p. ex.: o vulcão Augustine, no Alasca; o Popacatepetl, no México; o Kiauea, no Havaí; e, o Rabaul, na Nova Guiné. RIZOS et al. (1997) descrevem algoritmos de controle de qualidade para aplicações de receptores GPS permanentes.

SANTERRE \& LAMOUREUX (1997) apresentam algoritmos modificados para resolução de ambigüidade (OTF - On The Fly) para monitorar deformação de uma ponte com 1040 m de comprimento, em Quebec, Canadá. 
CHEN (1998) apresenta a monitoração contínua, com GPS, da deformação da crosta, utilizando-se dos dados da rede de deformação do oeste do Canadá (WCDA Western Canada Deformation Array). Esta rede iniciou em setembro de 1992 para estudar e avaliar os perigos de terremotos e movimentos tectônicos. A pesquisa de Chen tem como objetivo realizar uma avaliação contínua, dia a dia, da monitoração de deformação da crosta, no período de setembro de 1992 a abril de 1995, totalizando 31 meses. O programa utilizado por Chen foi o CGPS22, a versão canadense do GPS22 do NGS, e conclui que precisões de 2,3 a 4,5 milímetros (horizontal) e de 5,9 a 8.7 milímetros (vertical), para repetibilidade a longo prazo, foram obtidas rotineiramente na análise dos dados da rede WCDA. Para repetibilidade a curto prazo, semanal, os resultados obtidos foram de 1,8 a 3,5 milímetros nas componentes horizontal e de 6,3 a 8,3 milímetros nas verticais.

SCHAAL (1998) apresenta uma metodologia para qualificar os resultados de uma observação GPS e processos para minimizar os desvios sistemáticos nas medições decorrentes do multicaminhamento. Desenvolveu o programa ANÁLISE para ler os dados do arquivo do GPPS (Ashteck) e calcular o desvio padrão dos resíduos totais dos valores da média móvel e dos valores aleatórios. Exemplifica sua pesquisa com medições de deslocamento em obras civis de grande porte com GPS. Também realiza medições nas bases da Universidade Federal de São Carlos (UFScar) e da Universidade de São Paulo (USP). Os programas utilizados por SCHAAL (1998) para processar os dados GPS foram: OMNI (NGS), SKI (LEICA), TRIMVEC PLUS (TRIMBLE), GPSurvey (TRIMBLE), GPPS (ASHTECK) e SPCETRUM SURVEY (SOKKIA).

MARTIN \& JAHN (1998) descrevem o sistema de rede de alta precisão com correção diferencial em tempo real para aplicações geodésicas. Apresentam os métodos de comunicação e planejamento de locais e freqüência. A idéia básica consiste numa rede permanente de posicionamento de alta precisão, cujos pontos de referência são precisamente levantados e conectados via rádio. Dentro desta rede, calculam-se os parâmetros de correção da área, os quais modelam as influências dos erros. Cada estação é monitorada e controlada por uma estação de referência principal, na qual os dados são coletados e armazenados. Os pesquisadores concluem que o custo e o tempo de levantamento devem diminuir, pois o usuário necessita 
somente de um receptor GPS móvel e de um modem VHF de rádio. Além disto, Martin e Jahn recomendam investigações na modelagem dos erros da ionosfera, em virtude do aumento das atividades solares, e nas variações do centro de fase da antena.

Um sistema baseado na rede SCIGN para monitorar deformação estrutural na barragem Pacoima, Los Angeles, Califórnia, utilizando-se do sistema GPS contínuo é apresentado por BEHR et al. (1999). Tanto o planejamento quanto as comunicações e as operações deste sistema fundamentam-se na rede SCIGN. O processamento inicial dos dados GPS realiza-se com o programa GAMIT do Instituto de Tecnologia de Massachusetts (MIT - Massachusetts Institute of Technology), Cambridge, EUA, estimando as coordenadas da estação, os parâmetros orbitais e as ambigüidades de fase. As estimativas para a rede da barragem Pacoima são obtidas com o programa GLOBK que realiza um ajustamento com filtro de Kalman. Os pesquisadores concluem que este experimento com a barragem de Pacoima, demonstra a aplicabilidade do GPS contínuo em monitoração estrutural.

Um programa para deformação desenvolvido pelo Distrito de Água Metropolitano da Califórnia Meridional (MWD - Metropolitan Water District of Southern California), monitora deslocamentos maiores do que dez milímetros com confiabilidade de 95\% para barragens de terra, e menores do que cinco milímetros para estruturas de concreto, segundo DUFFY \& WHITAKER (1999). O intervalo entre as observações é de seis meses, e os dados são monitorados em três dimensões. O deslocamento horizontal é obtido com estação total ou com receptores GPS, enquanto o vertical com níveis eletrônicos. Este programa está sendo beneficiado com as estações de referência de operação contínua (CORS - Continuous Operating Reference Station) do sistema que monitora as deformações da crosta no sul da Califórnia com a rede SCIGN. Muitas das estações desta rede SCIGN estão sendo implantadas nas construções do MWD, ou, nas proximidades destas. Estas estações consistem de receptores GPS de duas freqüência, com antena Dorne-Margolin choke ring. Os dados coletados foram processados com efemérides precisas, ou, rápidas, quando as precisas não estavam disponíveis. Os autores concluem que a redução de custo e o aumento de precisão das posições relativas mostram que o método utilizado e o uso da rede CORS são melhores do que os procedimentos anteriores. Duffy e 
Whitaker também esperam que futuramente o GPS forneça posicionamento tridimensional com precisões necessárias para monitorar deformação de barragens e reservatórios de terra e de concreto. O método utilizado foi denominado de "método de vetor mínimo", que trata cada ponto como uma rede independente. Para cada local, selecionam-se duas estações (p. ex.: CORS) como pontos de controle, os quais são estabelecidos como valores fixos. Portanto, medem-se dois vetores para cada ponto monitorado. Este método foi decidido com consultoria do Dr. Adam Chrzanowski do Departamento de Geodésia e Engenharia Geomática da UNB.

\subsection{Análise dos sistemas}

Os sistemas apresentados nas seções anteriores têm diversas aplicações como por exemplo: barragens; áreas de deslizamentos; movimentos da crosta; projetos industriais e científicos; túneis; vibrações estruturais de uma torre; redes de nivelamento; vulcões; pontes e obras civis de grande porte. Isto demonstra a diversificação de sistemas de monitoração de deformação que se utilizam do GPS em vários projetos e obras de engenharia.

Alguns resultados obtidos, nestes sistemas, foram: precisão de três milímetros, horizontalmente e verticalmente, para bases de trezentos metros de comprimento (FRODGE, 1992); variação da posição no nível do milímetro (HEIN \& RIEDL, 1995); precisões de 2,3 a 4,5 milímetros (horizontal) e de 5,9 a 8,7 milímetros (vertical) para repetibilidade a longo prazo (CHEN, 1998); precisões de 1,8 a 3,5 milímetros nas componentes horizontais e de 6,3 a 8,3 milímetros nas verticais para repetibilidade a curto prazo, semanal (CHEN, 1998); deslocamentos maiores do que cinco milímetros para estruturas de concreto (DUFFY \& WHITAKER, 1999). As precisões milimétricas alcançadas nos respectivos sistemas confirmam a utilização do GPS nos estudos relacionados com deformações. A aplicação do GPS na determinação dos parâmetros que descrevem a mudança da forma de um corpo, no espaço tridimensional, com a relação deformação-deslocamento, foi evidenciada por CHRZANOWSKI et al. (1986).

A implementação de um sistema para monitorar deformação de estruturas de engenharia civil (barragens, pontes, torres, grandes construções, ...) e de processos 
geodinâmicos (movimento da crosta, deslizamentos, áreas de mineração, ...) com GPS necessita das seguintes fases: otimização de rede GPS, projetando-a de maneira precisa, confiável e capaz de detectar as deformações de modo mais econômico possível; aquisição e ajustamento das quantidades medidas com os métodos de levantamento de deformação; descrição do estado geométrico do corpo deformador, selecionando o modelo de deformação, estimando os parâmetros, calculando e representando as deformações com esta análise geométrica; e interpretação física de deformação, estabelecendo as relações carga-deformação e os modelos de predição.

O custo e o tempo dos levantamentos com GPS devem diminuir, segundo MARTIN \& JAHN (1998), pois o usuário necessitará somente de um receptor GPS, se existir uma estação de referência na região de interesse, como por exemplo as da Rede Brasileira de Monitoramento Contínuo (RBMC) da Fundação Instituto Brasileiro de Geografia e Estatística (IBGE). Assim, prevê-se um aumento na utilização do GPS na monitoração, análise e medição de deformação.

As análises destes sistemas, seus resultados, suas fases e suas aplicações corroboram com o interesse no estudo do comportamento dinâmico de deformação de estruturas de engenharia, LOVSE et al. (1995). Isto salienta a necessidade de dar continuidade a esta pesquisa. Outros fatos que também fortalecem a realização desta investigação são a necessidade de desenvolver um sistema de rede GPS para monitorar deformação, ROBERTS \& RIZOS (1997) e os estudos nas variações do centro de fase da antena do receptor GPS, MARTIN \& JAHN (1998). Além disto, os desafios por BOCK \& SHIMADA (1989) e ROBERTS \& RIZOS (1997) estimularam o desenvolvimento desta tese. Para Bock e Shimada, o principal desafio é analisar e interpretar corretamente os dados coletados, em tempo adequado, para distinguir entre deformação e ruído da medição. Assim, deve-se coletar, processar, compreender e arquivar grandes volumes de dados, de maneira eficiente e rápida. Para Roberts e Rizos, o desafio consiste em desenvolver um sistema automático de rede GPS para monitorar aplicações em escala pequena, como por exemplo a monitoração de vulcões. 


\section{ETAPAS: otimização, observação, análise geométrica e interpretação}

O processo de monitoração de deformação com GPS inicia-se com a otimização de redes GPS para análise de deformação, investigando a melhor configuração e o melhor esquema de observação. Em seguida, tratam-se os dados GPS, formatando-os, verificando-os e processando-os. As soluções obtidas nos (pós) processamentos contribuem para a análise geométrica, determinando-se os parâmetros de deformação. Conhecendo-se as características da estrutura investigada, pode-se realizar uma interpretação física com base nas deformações e na relação carga-deformação.

Nesta pesquisa, as etapas de otimização e interpretação física não são experimentalmente realizadas; a primeira, em virtude de utilizar somente um ponto de referência, e a segunda, pelo não conhecimento das relações carga-deformação e das propriedades dos materiais do corpo deformado.

Assim, os experimentos contidos nesta pesquisa tratam das etapas relacionadas com as observações GPS e a análise geométrica. A primeira é enfatizada pelo uso dos programas TEQC e GIPSY, nas investigações no edifício e na simulação de deslocamentos, ambas com dados coletados no receptor Z-XII e com processamentos (estático e cinemático) utilizando efemérides precisas não fiduciais do JPL; enquanto a segunda está contida na movimentação dos tabuleiros num viaduto e na simulação de deformação, com enfoque no teste de congruência global e nas relações deslocamento-deformação para a respectiva simulação.

\subsection{Otimização de redes GPS}

O problema de otimização de redes GPS é encontrar a melhor configuração de satélites e estações no terreno e o melhor esquema de observação cuja exatidão 
satisfaça o critério de qualidade da rede prescrita com relação a precisão, confiabilidade e detecção de deformação com um custo mínimo, KUANG (1996). Os problemas (ou ordens) de uma rede GPS são:

a) Ordem Zero (definição do melhor datum): o sistema de referência definido pelas estações globais de rastreio para gerar as efemérides transmitidas ou precisas;

b)Primeira Ordem (projetar a melhor configuração possível da rede): subdividida nas seguintes partes:

b.1) "design" de redundância GPS: número de observações maior ou igual ao número de incógnitas;

b.2) "design" de configuração GPS: geometria de satélite e estação no terreno (DOP);

b.3) "design" logístico GPS: selecionar receptores para configuração com custo mínimo.

c) Segunda Ordem (pesos das observações): qualidade do levantamento GPS é influenciado por erros sistemáticos não modelados;

c.1) confiabilidade interna: detectar erros sistemáticos (resolução da ambigüidade de ciclos, erros do relógio, atrasos ionosférico e troposférico);

c.2) confiabilidade externa: minimizar o efeito dos erros sistemáticos não modelados nas coordenadas estimadas; modelar tendência das observações; modelar os efeitos dos erros orbitais; modelar o comportamento do relógio; modelar as influências atmosféricas na propagação do sinal GPS; modelar as influências de qualquer tendência modelada inadequadamente ou não modelada; selecionar modos de medição: portadora ou código; selecionar o intervalo para o rastreio; selecionar a máscara de elevação (normalmente, de 8 a $15^{\circ}$ ) para reduzir o modelo troposférico; selecionar horário adequado para o rastreio, reduzindo o efeito ionosférico; selecionar os instrumentos (receptores). 
d)Terceira Ordem (melhoramento da rede existente): integração do GPS com as redes terrestres existentes (triangulação, trilateração, poligonação, nivelamento, etc.).

Planejar um levantamento GPS, segundo KUANG (1996), é projetar uma geometria (satélites-receptores), escolher os instrumentos e modelar as tendências com um custo mínimo, podendo-se expressar como:

$$
\alpha_{p}(\text { precisão })+\alpha_{r}(\text { confiabilidade })+\alpha_{s}(\operatorname{det} e c c ̧ \tilde{a} o)+\alpha_{c}(\text { custo })^{-1}=\max , \quad \text { (5.1) }
$$

na qual, $\alpha_{p}, \alpha_{i}, \alpha_{e}$ e $\alpha_{c}$ são os coeficientes ponderados para precisão, confiabilidade interna, confiabilidade externa e custo, respectivamente.

A otimização de redes GPS tendo em vista precisão e confiabilidade, ainda é o primeiro passo em direção ao sucesso do levantamento, KUANG (1996).

Teoricamente, a melhor precisão e confiabilidade das posições relativas de uma rede GPS pode ser obtida se todos os satélites visíveis são rastreados e todas as bases possíveis na rede são medidas. Segundo KUANG (1996), por causa das limitações de tempo e de custo, isto raramente ocorrerá na prática, e portanto, um ótimo projeto de levantamento deve ser realizado para obter os critérios estabelecidos com mínimo esforço.

A qualidade de uma rede GPS geralmente depende dos seguintes fatores, KUANG (1996):

i) geometria da configuração dos satélites e das estações terrestres da rede;

ii) precisão das observações (pseudodistâncias e fases da portadora);

iii) quantidade e distribuição das bases quase-independentes medidas.

Normalmente, as variáveis que o usuário tem para decidir são a quantidade e a distribuição das bases quase-independente $\mathrm{O}$ comprimento e a orientação da base afetam a precisão das componentes da base, isto é, das posições relativas.

No caso de redes GPS relativas, o custo do levantamento de campo é proporcional ao número total de bases quase-independentes observadas. KUANG (1996) argumenta que um esquema ótimo de levantamento deve ter um número total mínimo de bases. 
A seleção de bases ótimas é muito trabalhosa no método de tentativa e erro e nunca pode encontrar o conjunto de bases teoricamente ótimo. Para KUANG (1996), uma solução inteiramente analítica para o problema de otimização torna-se necessário.

Qualquer problema de otimização de rede é sempre relacionado ao ajustamento de observações, utilizando-se da matriz design, da matriz peso e da matriz variânciacovariância, contidas no modelo matemático estabelecido para o ajustamento e a avaliação das observações coletadas. Portanto, conforme KUANG (1996), entender os modelos de ajustamento GPS e avaliar a influência dos erros sistemáticos são os pré-requisitos para o projeto de levantamento GPS.

\subsection{Observação: aquisição e processamento de dados GPS}

\subsubsection{Aquisição, formatação e verificação dos dados GPS com receptores ASHTECH Z-XII, TRIMBLE 4600LS A TRIMBLE 4000SSI}

Nesta pesquisa, obtiveram-se os dados GPS com os receptores Ashtech Z-XII e TRIMBLE 4600LS. Além destes, utilizam-se os dados da estação UEPP da RBMC, coletados no receptor TRIMBLE 4000SSI. Os receptores TRIMBLE 4600LS pertencem à Fundação de Ciência, Tecnologia e Ensino (FUNDACTE) de Presidente Prudente/SP, colocando à disposição dos usuários do Laboratório de Astronomia, Topografia e Geodésia (LATOGEO) da Faculdade de Ciências e Tecnologia (FCT) da Universidade Estadual Paulista (UNESP), Campus de Presidente Prudente. Os dados da UEPP foram cedidos por sylvio@,ibge.gov.br.

Os possíveis tipos de observáveis com o Z-XII são L1, L2, C1, P1, P2, D1 e D2. As medidas de fase em cada freqüência denominam-se L1 e L2; a pseudodistância usando o código C/A em L1 é designada por $\mathrm{C} 1$; as pseudodistâncias usando o código P em ambas freqüências são P1 e P2; e as freqüências Doppler representadas por D1 e D2. O modelo de antena utilizado com este equipamento é o 700700(C).

O TRIMBLE 4600LS pode ter as seguintes observações: L1, C1 e D1. A antena utilizada com este receptor tem o seguinte modelo: 4600LS INTERNAL. 
A estação UEPP é equipada com o TRIMBLE 4000SSI. Os tipos de observações com este receptor são: L1, L2, C1, P2, D1 e D2. A antena instalada nesta estação é a DORNE MARGOLIN T.

A taxa de rastreio das observações GPS foi coincidente com a da estação UEPP, ou seja, de 15 segundos.

Após a aquisição dos dados, estes foram convertidos para RINEX (Receiver Independent Exchange Format) e verificado a qualidade dos mesmos. Este formato, desenvolvido pelo Instituto Astronômico da Universidade de Berne (AIUB Astronomical Institute University of Berne), surgiu da necessidade de processar dados coletados com receptores de diferentes fabricantes, durante a campanha GPS realizada na Europa em 1989 (EUREF 89). Este formato padroniza os dados para entrada nos programas que processam observações GPS. A versão RINEX vigente durante o desenvolvimento desta pesquisa é a 2.10, GURTNER (2000). Exemplos de programas que realizam esta conversão são: TEQC (Translate/Edit/Quality Check) da UNAVCO (http://www.unavco.ucar.edu/); ASRINEXO (para receptores Ashtech) e TRRINEXO (para receptores Trimble) do AIUB (http://morgoth.unibe.ch/aiub/).

Quando os dados coletados com receptores do mesmo fabricante (p. ex.: TRIMBLE) são processados com o programa comercial (p. ex.: o GPSurvey do fabricante dos receptores TRIMBLE), não há necessidade de converter os dados binários (*.DAT, para receptores Trimble), coletados no campo, para o formato RINEX. Dados de fabricantes diferentes requerem a conversão para o formato RINEX.

No processamento com o programa científico GIPSY, o módulo de entrada é composto dos dados RINEX das estações de interesse. Nesta pesquisa, utilizou-se o TEQC para gerar os arquivos RINEX. Este programa, além de oferecer a opção de transladar os dados binários de um receptor (p. ex.: Trimble DAT) para o formato RINEX, permite a edição e/ou correção de informações no cabeçalho dos arquivos destes dados (p. ex.: tipo de receptor, tipo de antena), e a verificação dos dados GPS, com ou sem efemérides.

Tanto para a conversão em RINEX, quanto para o controle de qualidade dos dados GPS elaboraram-se arquivos em lote (*.bat) para realizar estas tarefas. 
Trecho inicial de um arquivo RINEX encontra-se no ANEXO A. Detalhes do conteúdo de um arquivo RINEX estão em GURTNER (2000). Os interessados devem consultar esta referência para maiores esclarecimentos.

O ANEXO B exemplifica o uso do TEQC no controle de qualidade do arquivo Uepp1711.00O, obtendo-se o arquivo UEPP1711.qc contendo informações relacionadas com as observações do respectivo arquivo. Assim, obtém-se o arquivo com os dados GPS para o processamento dos mesmos.

\subsubsection{Processamento dos dados GPS com os programas GPSurvey e GIPSY}

Tendo as efemérides e as observações GPS, processam-se os dados com um programa científico (p. ex.: GIPSY) ou comercial (p. ex.: GPSurvey). Para os experimentos realizados nesta pesquisa, processaram-se os dados GPS com o GIPSY para as observações realizadas no prédio e na simulação do deslocamento, e com o GPSurvey para as investigações no viaduto e nas simulações de deformação.

O programa GIPSY-OASIS II (GPS Inferred Positioning System - Orbit Analysis and SImulation Software II) encontra-se disponível na FCT/UNESP, mediante um Contrato (No. 021497) entre a CALTECH/JPL (California Institute of Technology/Jet Propulsion Laboratory) e a respectiva Faculdade. Este programa, desenvolvido e distribuído pelo JPL, processa dados GPS e observações de outras técnicas de Geodésia espacial, p. ex.: SLR e DORIS (Doppler Orbitography and Radiopositioning Integrated by Satellite).

O programa GPSurvey (versão 2.35a) desenvolvido pela TRIMBLE (Trimble Navigation Limited), encontra-se disponível aos usuários do LATOGEO da FCT/UNESP.

A opção de processar os dados da pesquisa com um programa científico, no caso o GIPSY, em virtude da sua disponibilidade na FCT/UNESP (Instituição à qual o autor da pesquisa encontra-se vinculado), ratifica a posição de OLIVEIRA (1998) quanto ao processamento da rede realizar-se com um programa científico. Os experimentos processados com este programa compreendem aqueles cujas observações GPS realizam-se com o receptor Z-XII, pois este tem duas freqüências. 
Os tipos de observáveis utilizadas no GIPSY, para cada equipamento, são definidos na etapa de processamento.

Para as observações com os receptores 4600LS de uma freqüência, utiliza-se o programa comercial GPSurvey para o processamento dos dados. Há outros programas comerciais que poderiam ser utilizados, porém optou-se pelo GPSurvey em razão deste ser uma nova versão do utilizado na dissertação de mestrado (CHAVES, 1994), e pela familiarização com o referido programa.

\subsubsection{GPSurvey}

Este programa requer, inicialmente, a criação de um novo projeto (p. ex.: Viaduto), para transferir, posteriormente, os dados diretamente do receptor, ou dos arquivos RINEX, ou de outra opção oferecida pelo programa.

Processam-se as bases com o GPSurvey e finaliza-se com o ajustamento da rede processada. Com os resultados obtidos nos processamentos dos dados GPS, utilizando-se o programa GPSurvey, efetua-se a análise geométrica dos pontos investigados, o teste de congruência global para análise de estabilidade entre as épocas observadas, e a determinação dos parâmetros envolvidos na pesquisa.

O GPSurvey oferece outras opções (planejamento, visualização, utilitários), além do processamento. Os interessados devem recorrer à ajuda do programa para obter maiores informações.

\subsubsection{GIPSY}

O programa GIPSY teve a sua primeira demonstração em 1985, conforme UNAVCO (2000), com a análise do teste de uma base de alta precisão em março do respectivo ano. A precisão obtida no referido teste alcançou uma parte por bilhão (1 ppb), demonstrando a sua eficácia. O programa contém mais de quatrocentas mil linhas de código e foi desenvolvido por vários engenheiros, cientistas e estudantes, durante muitos anos. Fluxograma e principais programas do GIPSY estão no ANEXO C. Segundo UNAVCO (2000), o GIPSY teve origem em dois sistemas independentes: programa para determinação de órbita e um programa VLBI 
geodésico. Em 1985, combinaram-se estes dois sistemas com mais um programa com Filtro de Kalman para estimação de parâmetros. Ao mesmo tempo, desenvolveu-se um programa com módulos comuns, denominado OASIS, para análise de covariância para órbitas e missões espaciais. O termo GIPSY-OASIS refere-se à união destes programas. Inicialmente, o GIPSY-OASIS desenvolveu-se no sistema operacional VMS (para máquinas VAX), e no período de 1991 a 1992 rescreveu-se o GIPSY para ser executado no sistema operacional UNIX em estações de trabalho Sun e HP. A versão para UNIX é denominada de GIPSY-OASIS II.

O GIPSY processa dados obtidos com os métodos de posicionamento estático, rápido estático e cinemático. O modo mais usual do GIPSY é o estático, ocupando-se a estação por várias horas. No rápido estático, coletam-se dados entre $5-10$ minutos e não há necessidade de continuar coletando durante a mudança de local. Os dados no cinemático são coletados continuamente. Todos os dados são pós-processados, pois os programas de estimação e modelagem são diferentes e executados separadamente, inviabilizando o processamento em tempo real.

Utilizando-se do filtro denominado de SRIF (Square Root Information Filter), numericamente estável, consegue-se reduzir o problema de inversão de matrizes de dimensões, p. ex., de cinqüenta mil por doze mil, para inversão de lotes de matrizes menores, segundo GREGORIUS (1996). A diferença entre este filtro e o de Kalman seqüencial padrão é que o SRIF trata com a raiz quadrada da matriz covariância, garantindo a estabilidade da inversão. Gregorius observa que a raiz quadrada de uma matriz é obtida se a matriz for estável.

O principal aspecto que diferencia o GIPSY dos outros programas, segundo UNAVCO (2000), é a não utilização de duplas diferenças.

Os dados de entrada para o GIPSY constituem-se nas observações GPS, as quais devem estar no formato RINEX, nas órbitas dos satélites, nos parâmetros de orientação da Terra, no campo de gravidade terrestre, nas posições de outros corpos no sistema solar, e nas posições da estação origem.

Após o processamento, dentre as possíveis soluções apresentadas no GIPSY estão a matriz covariância e o vetor estimado, os gráficos e as tabelas dos resíduos das medidas pré e pós ajustados, as componentes da base em vários sistemas de 
coordenadas, as órbitas dos satélites, a evolução dos parâmetros estocásticos, tais como atraso dos relógios e o atraso troposférico, e a repetibilidade da base.

Esta pesquisa utiliza-se do GIPSY para processar as observações GPS, as quais são modeladas pelas seguintes equações:

$$
\begin{aligned}
& \mathrm{L}=\rho+\mathrm{c}(\mathrm{dt}-\mathrm{dT})+\lambda \mathrm{b}-\mathrm{d}_{\text {ion }}+d_{\text {trop }}, \\
& \mathrm{P}=\rho+\mathrm{c}(\mathrm{dt}-\mathrm{dT})+\mathrm{d}_{\text {ion }}+d_{\text {trop }} .
\end{aligned}
$$

onde $\mathrm{L}$ é a fase da portadora, $\mathrm{P}$ a pseudodistância, $\rho$ a distância entre as antenas do receptor e do satélite, c a velocidade da luz, dt e dT são as correções dos relógios do satélite e do receptor, $b$ é a ambigüidade, $\mathrm{d}_{\text {ion }}$ e $\mathrm{d}_{\text {trop }}$ são os atrasos ionosférico e troposférico, respectivamente. Os ruídos dos dados, multicaminhamento e outros efeitos perturbadores estão incorporados em $\rho$. Segundo CHEN et al. (1998), o GIPSY modela ou remove os erros dos efeitos atmosféricos, multicaminhamento e erros orbitais.

Os possíveis tipos de observações no arquivo RINEX 2.10 são:

- L1, L2: medida da fase em L1 e L2;

- C1: pseudodistância usando o código C/A em L1;

- P1, P2; pseudodistância usando o código P em L1 e L2;

- D1, D2: freqüência Doppler em L1 e L2;

- T1, T2; Transit Doppler Integrado em $12^{\circ}$ (T1) e $400 \mathrm{MHz}$ (T2).

Com os dados de entrada, necessários para o processamento, o GIPSY estima os parâmetros e os resíduos com os programas filter, smapper e postfit, utilizandose do filtro SRIF. As observações são modeladas em função dos parâmetros, ou seja, modelo de ajustamento paramétrico, e linearizando o modelo com fórmula de Taylor, obtém-se a seguinte, GREGORIUS (1996):

$$
z=F(x) \approx F\left(x_{0}\right)+F^{\prime}\left(x_{0}\right)\left(x-x_{0}\right)
$$

onde $\mathrm{z}$ corresponde às observações, $\mathrm{x}$ os parâmetros, $\mathrm{x}_{0}$ os valores nominais dos parâmetros do modelo, e $\mathrm{F}^{\prime}\left(\mathrm{x}_{0}\right)$ a matriz das derivadas parciais.

Rescrevendo a eq.(5.4), tem-se:

$$
z=A x+v
$$


onde $z$ é a diferença entre o valor observado e o calculado $\left[\mathrm{z}-\mathrm{F}\left(\mathrm{x}_{0}\right)\right], A$ a matriz das derivadas parciais dos parâmetros, também denominada de matriz configuração (matriz design) $\left[\mathrm{F}^{\prime}\left(\mathrm{x}_{0}\right)\right], x$ o vetor correção dos parâmetros $\left(\mathrm{x}-\mathrm{x}_{0}\right)$, e $v$ o vetor dos resíduos. O GIPSY realiza o ajustamento pelo método paramétrico, utilizando-se do SRIF para evitar problemas com inversão de matriz.

Nesta pesquisa, as etapas envolvidas com o programa científico GIPSY são: órbitas utilizadas, dados de entrada, processamento com o XT-GIPSY, soluções e processamento cinemático. Estas etapas são descritas a seguir.

\section{a) Órbitas utilizadas no GIPSY}

No processamento com o GIPSY utilizam-se as efemérides precisas, não fiduciais, do JPL. Para a aquisição destas órbitas, utiliza-se o script fetch_orbits, o qual obtém, descompacta, manipula e renomeia, se necessário, os arquivos relacionados com as respectivas órbitas. Executa-se este script via telnet (protocolo usado na Internet para permitir que um computador acesse outro e nele execute programas), na estação de trabalho Sun Ultra 1, com o seguinte comando:

\section{nohup fetch_orbits yymmmdd \&,}

onde $y y$ corresponde ao ano, $\mathrm{mmm}$ ao mês e $d d$ ao dia. Para as efemérides não fiduciais, obtém-se onze arquivos, os quais estão na TABELA 5.1.

TABELA 5.1 - Arquivos das efemérides não fiduciais

\begin{tabular}{|l|l|}
\hline yyyy-mm-dd.ITRFyy_nf.qx.Z & XFILE \\
\hline yyyy-mm-dd.shad.Z & Shadow \\
\hline yyyy-mm-dd_nf.eci.Z & Peci \\
\hline yyyy-mm-dd_nf.tdpc.Z & TDPfile \\
\hline yyyy-mm-dd.tpeo_nf.nml.Z & tpeo.nml \\
\hline ReferenceFrame & \\
\hline
\end{tabular}

Os cinco primeiros arquivos da primeira coluna da TABELA 5.1 foram descompactados e renomeados pelo script fetch_orbits (os cinco arquivos da segunda coluna da respectiva tabela). $\mathrm{O}$ arquivo XFILE contém os parâmetros de 
transformação para um específico ITRF (International Terrestrial Reference Frame); o Shadow possui informações sobre o eclipse do satélite; o peci fornece as órbitas precisas no formato ECI; o TDPfile corresponde ao arquivo Time Dependent Parameter dos parâmetros precisos dos relógios GPS; o tpeo.nml contém informações sobre a rotação da Terra, movimento do pólo e do tempo. O último arquivo, ReferenceFrame, trata da base (frame) utilizada, neste caso, free-network.

Há outros produtos disponíveis pelo JPL, conforme consta na mensagem eletrônica (e-mail), n.1187, do IGS: órbitas preditas e as rápidas precisas. As preditas possuem uma acurácia de 50 a $80 \mathrm{~cm}$ para 24 horas de predição, e de 1 a $2 \mathrm{~m}$ para 48 horas. As soluções do relógio e órbitas GPS das rápidas precisas estão disponíveis 20 horas após o dia observado, com acurácia de $20 \mathrm{~cm}$ RMS (Root-Mean-Squares). Ambas as órbitas estão no formato SP3 (formato para órbita precisa do $N G S$ dos EUA).

As efemérides obtidas devem estar no diretório de trabalho, no qual realiza-se o processamento dos dados GPS desta pesquisa.

\section{b) Dados de entrada no GIPSY}

Após a aquisição das observações realizadas no campo, e a transferência das mesmas para o computador, converte-as para o formato RINEX e verifica suas qualidades, seguindo os procedimentos estabelecidos na seção 5.2.1.

Os arquivos contendo os dados GPS (arquivos RINEX) dos pontos investigados são inseridos no subdiretório denominado raw, onde realizam-se os processamentos deste trabalho.

Informações atualizadas sobre as estações processadas devem estar inclusas no diretório/goa/sta_info, criado durante a instalação do programa GIPSY. Há quatro arquivos neste diretório: sta_id, sta_pos, sta_svec e pcenter.

$\mathrm{O}$ arquivo sta_id contém um identificador para a estação, um número, um nome e comentários. Para a estação denominada PDCX, tem-se a seguinte linha:

\section{PDCX O PDCX manual joao Sex Abr 07 13:15:00 GMT 2000}

O sta_pos associa o identificador da estação, numa determinada época, com suas coordenadas e suas velocidades. Exemplo para PDCX: 


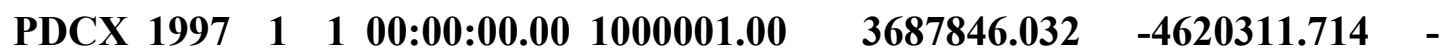
$2387695.2820 .00000000 \mathrm{e}+000.00000000 \mathrm{e}+000.00000000 \mathrm{e}+0020000615$ joao manual

O sta_svec estabelece a correspondência entre o identificador da estação e o tipo de antena, o qual deve estar contido no arquivo pcenter; fornece o vetor da estação, a altura da antena, um indicador para o tipo de coordenada utilizada (cartesiana ou local), uma data e um comentário. Para a estação PDCX, tem-se:

PDCX PDCX 1995 01 01 00:01:15.00 946080000.00 ASH70070C 0.0000 $0.0000 \quad 0.000000000 .0000120001231$ manual joao

O último arquivo, pcenter, possui o tipo de antena, o tipo do centro de fase e suas correções. Para a antena ASHTECH, utilizada com o Z-XII, tem-se:
ASH70070C L1 $\quad-0.0015 \quad-0.0018 \quad 0.0515 \quad$ Joao Carlos Chaves (15/05/00)
ASH70070C L2 0.0020 - $0.0011 \quad 0.0594$ (offsets do ARP ao centro de fase)
ASH70070C LC $-\mathbf{- 0 . 0 0 0 7} \quad-\mathbf{0 . 0 0 6 3} \quad 0.0393$

A TABELA 5.2 apresenta os tipos de receptores e antenas, e a identificação da antena no arquivo pcenter.

TABELA 5.2 - Tipos de receptores e antenas

\begin{tabular}{|l|l|c|}
\hline \multicolumn{1}{|c|}{ Tipo de Receptor } & \multicolumn{1}{|c|}{ Tipo de antena } & pcenter \\
\hline TRIMBLE 4000SSI & DORNE MARGOLIN T & ROGUE_T \\
\hline ASHTECH Z-XII & ASHTECH MARINE L1/L2 & ASH70070C \\
\hline
\end{tabular}

Estes arquivos devem ser cuidadosamente editados e verificados, antes de realizar o processamento dos dados.

As correções dos centros de fase, utilizadas nesta pesquisa, foram obtidas das calibrações das antenas publicadas pelo NGS (http://www.grdl.noaa.gov/GRD/GPS/Projects/ANTCAL.1/index.shtml). Detalhes dos procedimentos para a obtenção das respectivas calibrações, encontram-se em MADER (2000). 
De posse das efemérides, dos dados GPS e das informações das estações, podese realizar o processamento com o GIPSY. As maneiras para a execução deste programa são: manualmente ou automaticamente. A primeira opção requer muito conhecimento do próprio programa GISPY, quanto do sistema operacional UNIX. A segunda facilita a vida dos principiantes e das pessoas que não desejam digitar comandos ou escrever scripts, menciona GREGORIUS (1996) ao referir-se ao xtgipsy, uma interface gráfica que permite ao usuário processar dados GPS no GIPSY.

\section{c) Processamento no GIPSY com o XT-GIPSY}

O usuário pode executar o GIPSY com a interface gráfica denominada xtgipsy. Construída na plataforma UNIX, pode-se executá-la via telnet ou por um $X$ terminal. No diretório principal deve conter as informações orbitais e um subdiretório (raw) com os arquivos RINEX. Escolhe-se a estratégia pretendida, os tipos de dados, o objetivo do trabalho, e executa-se o programa. Há flexibilidade na análise dos dados e disponibilidade de ajuda para vários comandos.

Nesta pesquisa, utiliza-se o protocolo telnet para acessar o computador que contém o GIPSY (neste caso: ueppgps), conforme ilustrado na FIGURA 5.1.

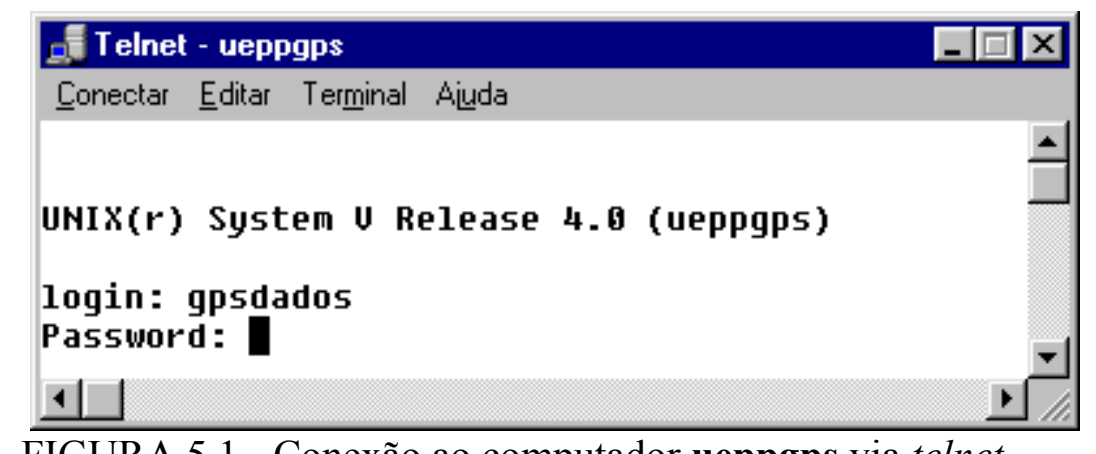

FIGURA 5.1 - Conexão ao computador ueppgps via telnet

Após conectado no computador de trabalho, o xterm é acessado com a linha de comando contida na FIGURA 5.2.

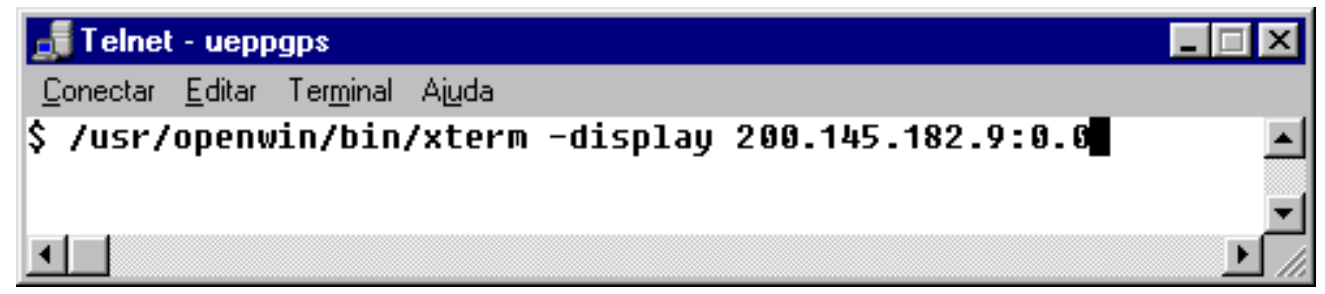

FIGURA 5.2 - Acesso ao xterm 
Com o programa MicroImages X Server, tech@microimages.com, (19/03/1997), instalado no computador pessoal, executa-se o xt-gipsy. A primeira decisão do usuário é escolher a sua estratégia de processamento. As opções incluem os levantamentos estático rápido (RSS - Rapid Static Survey); estimar órbitas e estações; fixar órbitas (transmitidas, precisas ou preditas) e outros parâmetros (p. ex.: clock); e posicionamento absoluto (por ponto) preciso (ppp - precise-point-position). Segundo CHEN et al. (1998), ao fixar as órbitas, os parâmetros de uma estação não tem correlação com os parâmetros de outra estação. As estratégias encontram-se no diretório/goa/bin/GOAMakefile. *.

A FIGURA 5.3 ilustra a execução do GIPSY e as opções para escolha da estratégia desejada.

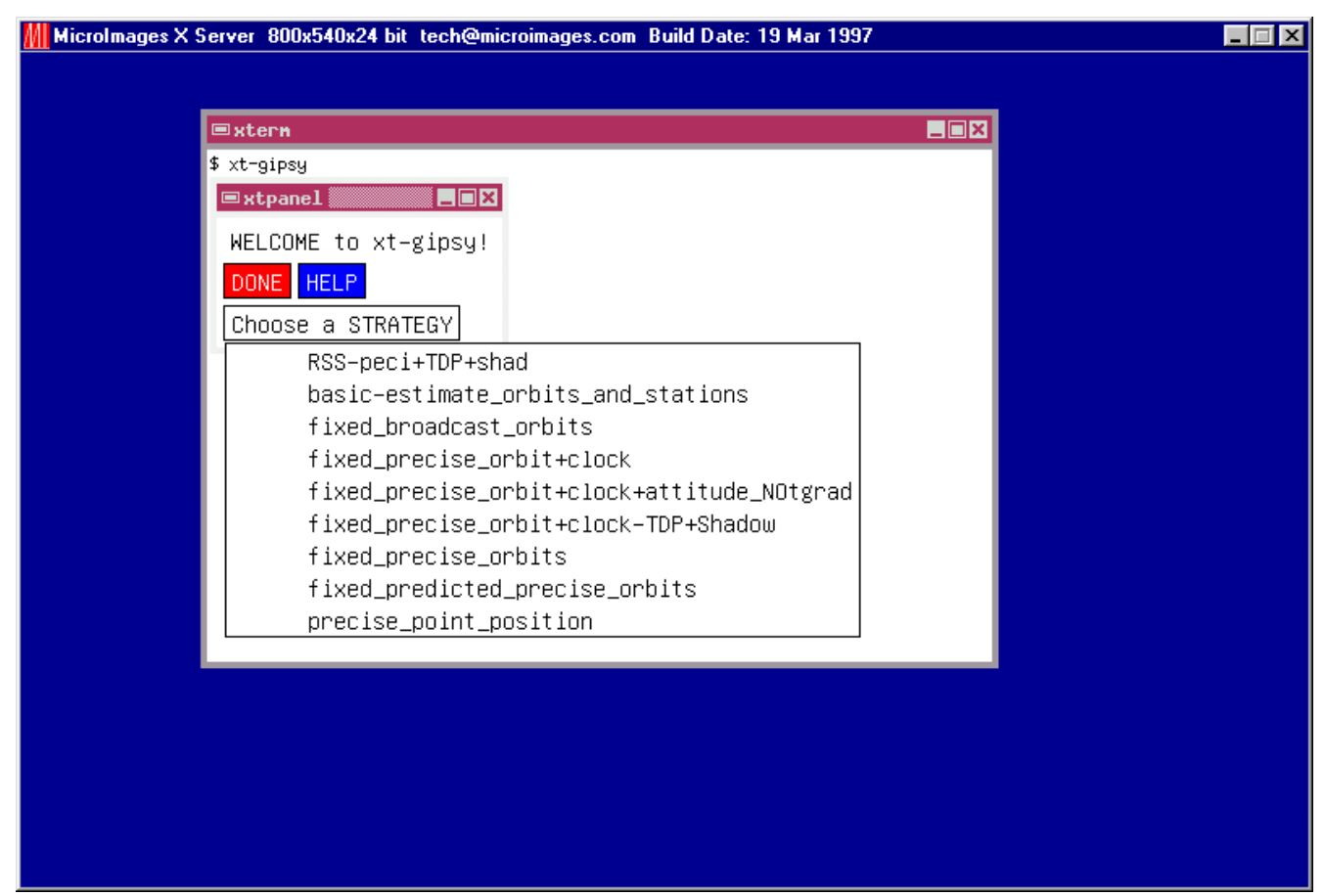

FIGURA 5.3 - Execução do GIPSY e opções de estratégias

Na próxima janela de consulta, o usuário deve escolher um objetivo (p. ex.: obtenção da solução bias_free.stacov) e decidir sobre alguns parâmetros, tais como:

- clock de referência: por default, é a primeira estação em ordem alfabética, segundo HURST (1995);

- estações fiduciais: escolhe-se a estação a ser fixada; 
- tipos de dados: tem-se as opções L1, L2, LC, P1, P2 e PC para a realização do processamento. LC e PC correspondem à combinação linear livre da ionosfera (ionosphere-free) para a fase da portadora e a pseudodistância, respectivamente.

Estas decisões estão ilustradas na FIGURA 5.4.

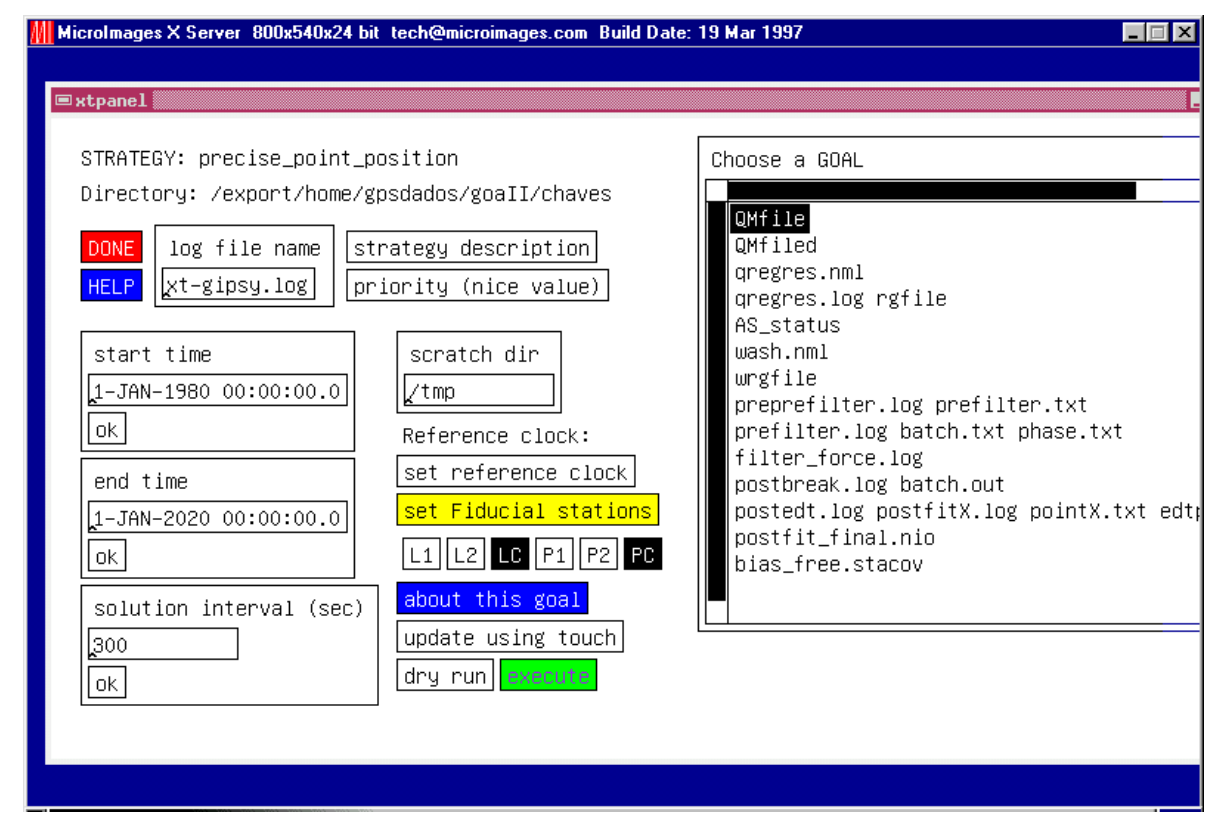

FIGURA 5.4 - Escolha de um objetivo e definições de parâmetros

O processamento realiza-se ao acionar a opção execute. No final, obtém-se as soluções das estações analisadas pelo usuário.

\section{d) Soluções dos processamentos com o GIPSY}

Pode-se estabelecer dois tipos de soluções. O primeiro corresponde às soluções resultantes dos processamentos, às quais denominam-se soluções processadas. $\mathrm{O}$ outro tipo advém de programas que processam as primeiras, ou seja, correspondem às soluções pós-processadas.

\section{- Processadas}

O processamento com o GIPSY para estimar os parâmetros e os resíduos das estações de interesse, realiza-se com os programas filter, smapper e postfit. 
Dependendo da estratégia e do objetivo escolhidos no processamento, obtém-se uma das seguintes soluções: bias_free ou bias_fix. A primeira refere-se às soluções sem resolver as ambigüidades, enquanto a outra trata dos resultados com a fixação das mesmas. Para a obtenção das soluções bias_fix, há necessidade de conseguir as soluções sem fixar a ambigüidade, ou seja, as bias_free.

As soluções bias_free contendo as coordenadas e os desvios-padrão das estações estimadas, provém do arquivo smcov.nio. O arquivo com estas soluções é gerado com o programa stacov.

$\mathrm{O}$ arquivo bias_fix procede do programa ambigon2, utilizando o smcov.nio. como arquivo de entrada.

\section{- Pós-processadas}

Com as soluções diárias processadas, calculam-se as posições, as componentes das bases, e o time series das coordenadas das estações com suas respectivas velocidades. Se necessário, estas coordenadas podem ser transformadas para outra base de referência. O GIPSY possui vários programas para a realização destas investigações; segundo GREGORIUS (1996), há pouca documentação sobre estes recursos. Estes programas, stacov, heightfix, stamrg, project, statistics e transform auxiliam na análise das coordenadas das estações.

Após o processamento dos dados GPS, aplicam-se os parâmetros de transformação (contidos no arquivo XFILE) para as soluções diárias, obtendo-se as coordenadas na mesma base de referência, p. ex.: ITRF97. Isto é possível com o programa apply, que lê o arquivo XFILE e aplica 7 ou 14 parâmetros de transformação no arquivo de entrada (p. ex.: bias_free.stacov), produzindo um arquivo de saída (p. ex.: bfree_qitrf.stacov) num novo sistema de coordenadas (p. ex.: ITRF97). Assim, transformam-se as soluções de uma base de referência, freenetwork, para uma específica base, ITRF. Uma linha de comando explicativa para executar esta transformação é:

apply -x XFILE -i bias_free.stacov -o bfree_qitrf.stacov $-r-t$-s -cv, 
na qual, (-i) corresponde ao arquivo de entrada, (-o) ao de saída, e os demais (-r, -t, s) aos parâmetros de transformação. A opção (-cv) inclui os parâmetros no arquivo de saída (bfree_qitrf.stacov).

Com as soluções diárias transformadas, utiliza-se o programa stamrg para combiná-las e estimar as posições. Se houver interesse em obter as velocidades para uma determinada época de referência, deve-se acrescentar a opção: -v yymmmdd. Caso omitir esta opção (-v), nenhuma velocidade é estimada e o arquivo combinado corresponde a uma média ponderada de todos os arquivos de entrada. Exemplo de uma linha de comando para obter a solução combinada é:

stamrg -i d*_bias_free.stacov -o comb_bias_free.stacov.

As componentes da base e sua repetibilidade em vários sistemas de coordenadas são determinadas com o programa statistics. Para obter o time series com este recurso, utiliza-se a opção (-gds), gerando os arquivo com as respectivas séries para as estações processadas. A linha de comando para esta opção é:

\section{statistics -r comb_bias_free.stacov -i d*_bias_free.stacov -gds,}

na qual, a opção (-r) refere-se ao arquivo de referência para o cálculo das repetibilidades. Neste exemplo, geram-se também os arquivos com as repetibilidades para cada estação, e com as componentes da base.

Nesta pesquisa, elaboraram-se arquivos com os comandos necessários para a obtenção das soluções pós-processadas.

Maiores detalhes sobre estes programas e os recursos para pós-processamento de posições, velocidades, repetibilidades, componentes da base e time series encontram-se em HEFLIN (1995) e GREGORIUS (1996).

\section{e) Processamento cinemático com o GIPSY}

A monitoração de movimentos de uma estação, normalmente, realiza-se com o processamento cinemático, ou seja, modelam-se as posições desta estação estocasticamente. Endente-se por parâmetro estocástico, aquele cuja estimativa varia com relação ao tempo. A estimação estocástica das posições de uma estação requer a estratégia de fixar as órbitas, segundo GREGORIUS (1996). O GIPSY realiza esta estimação, gerando uma tabela (arquivo TDPTABLE) para a estação definida como 
estocástica. Para isso, necessita-se alterar o arquivo wash.nml, definindo a estação de interesse como estocástica (BUOYS) no grupo $\$ P R E P$ deste arquivo. Para gerar a tabela, necessita-se incluir os parâmetros definidos como estocásticos (WRTTDP) no grupo \$SMINPUT do arquivo wash.nml.

Com a tabela TDPTABLE, geram-se arquivos individuais para cada coordenada da estação processada e analisam-se os resultados entre épocas consecutivas.

\subsection{Análise geométrica de deformação}

Esta análise descreve o estado geométrico do corpo deformável, segundo CHRZANOWSKI \& CHEN (1990): mudança na forma e na dimensão, movimento do corpo rígido (translação e rotação) com relação a um sistema de referência, ou, de um bloco com relação a outro. Além destes movimentos, também deve-se determinar a existência de descontinuidades no corpo.

A análise geométrica de deformação consiste de três etapas, CHEN \& CHRZANOWSKI (1996): identificação dos modelos de deformação, estimativa dos parâmetros de deformação e verificação dos modelos.

A principal tarefa de uma análise geométrica é encontrar um modelo de deformação, expresso em termos de uma função deslocamento, que caracteriza a deformação no espaço e no tempo, CHRZANOWSKI et al. (1982) apud CHRZANOWSKI \& CHEN (1990). Como os levantamentos de deformação envolvem pontos discretos, a função que descreve o campo de deslocamento deve aproximar-se de um modelo selecionado, o qual ajusta-se às observações da melhor maneira possível. Se não há nenhuma tendência da deformação, ou, nenhum modelo predito, utiliza-se um polinômio geral para a obtenção do melhor modelo. A tendência de deformação colabora com a seleção do modelo de deformação, que descreve o estado geométrico do corpo deformado.

Os parâmetros de deformação, ou, os coeficientes do modelo são estimados com o método dos mínimos quadrados. Em seguida, verifica-se a adequação do modelo ajustado. 
Na análise de deformação, segundo MONICO (1988), deve-se, inicialmente, detectar os movimentos e, posteriormente, modelá-los. Esta modelagem não foi tratada por Monico.

\subsubsection{Seleção dos modelos de deformação}

CHEN (1983) apresenta uma forma de se obter um modelo preliminar da deformação por:

a) um conhecimento a priori, assumido ou esperado de experiências anteriores;

b) uma demonstração gráfica do campo de deslocamento no domínio do espaço, ou, dos deslocamentos versus o tempo.

Os parâmetros de deformação e os modelos de deformação, no caso geral, foram discutidos no capítulo 2. Para ilustração, as situações no espaço bidimensional são repetidas aqui com alguns exemplos de modelos típicos de deformação. Para cada bloco, os seguintes parâmetros de deformação no sistema de coordenadas (x,y) serão considerados: duas componentes $\left(a_{0}\right.$ e $b_{0}$, ou, $c_{0}$ e $g_{0}$, etc.) do deslocamento do corpo rígido; parâmetros de rotação $\omega(x, y)$; componentes de alongamento unitário $\varepsilon_{x}(x, y)$ e $\varepsilon_{\mathrm{y}}(x, y)$; e a distorção $\varepsilon_{x y}(x, y)$.

A deformação de um bloco é completamente determinado pela função deslocamento $\underline{d}(x, y)$. Se as duas componentes $u(x, y)$ e $v(x, y)$, nas direções $x$ e $y$, respectivamente, são dadas, então as componentes de deformação e a rotação diferencial em qualquer ponto pode ser calculado da relação deformaçãodeslocamento infinitesimal bem conhecida, eq.(2.4) e eq.(2.5):

$$
\varepsilon_{x}=\frac{\partial u}{\partial x}, \varepsilon_{y}=\frac{\partial v}{\partial y}, \varepsilon_{\mathrm{xy}}=\frac{1}{2}\left(\frac{\partial u}{\partial y}+\frac{\partial v}{\partial x}\right)=\frac{1}{2} \gamma_{x y} \text { e } \omega_{x y}=\frac{1}{2}\left(\frac{\partial v}{\partial x}-\frac{\partial u}{\partial y}\right)
$$

A função deslocamento é normalmente complicada, portanto, ela é aproximada por um polinômio. Das equações (2.32) e (2.31), um polinômio simplificado no espaço bidimensional pode ser escrito como:

$$
d x_{i}=u(x, y)=\sum_{i} \sum_{j} a_{i j} x^{i} y^{j}
$$




$$
d y_{i}=v(x, y)=\sum_{i} \sum_{j} b_{i j} x^{i} y^{j}
$$

Dependendo do modelo de deformação selecionado, alguns dos coeficientes nos polinômios da eq.(5.7) e eq.(5.8) serão cancelados. Exemplos de modelos típicos de deformação são dados abaixo, segundo CHEN (1983):

i) movimento de um único ponto ou movimento de corpo rígido (FIGURA 5.5a) de um grupo de pontos (bloco B) com relação a um bloco estável (bloco A); o modelo de deformação é:

$$
u\left(x_{A}, y_{A}\right)=0, v\left(x_{A}, y_{A}\right)=0, u\left(x_{B}, y_{B}\right)=a_{0}, v\left(x_{B}, y_{B}\right)=b_{0},
$$

onde $\left(x_{A}, y_{A}\right)$ representa os pontos no bloco A e $\left(x_{B}, y_{B}\right)$ no bloco B.

ii) strain homogêneo (FIGURA 5.5b) no corpo todo sem descontinuidade; para o corpo todo, o modelo de deformação linear é o seguinte:

$$
\begin{aligned}
& u(x, y)=a_{1} x+a_{2} y \text { e } v(x, y)=b_{1} x+b_{2} y \\
& u(x, y)=\varepsilon_{x} x+\varepsilon_{x y} y-\omega y \\
& v(x, y)=\varepsilon_{x y} x+\varepsilon_{y} y+\omega x
\end{aligned}
$$

iii) um corpo deformado com descontinuidade entre os blocos A e B, com deformação linear de cada bloco mais um movimento de corpo rígido de $\mathrm{B}$ com relação a A (FIGURA 5.5c):

$$
\begin{aligned}
& u\left(x_{A}, y_{A}\right)=a_{1} x+a_{2} y \\
& v\left(x_{A}, y_{A}\right)=b_{1} x+b_{2} y \\
& u\left(x_{B}, y_{B}\right)=c_{0}+c_{1} x+c_{2} y \\
& v\left(x_{B}, y_{B}\right)=g_{0}+g_{1} x+g_{2} y
\end{aligned}
$$

Para os casos anteriormente descritos, as componentes $\Delta x_{i}$ e $\Delta y_{i}$ de um deslocamento relativo total em qualquer ponto $i$ localizado na linha de descontinuidade entre os blocos A e B, podem ser calculados como:

$$
\begin{aligned}
& \Delta x_{i}=c_{0}+\left(c_{1}-a_{1}\right) x_{i}+\left(c_{2}-a_{2}\right) y_{i} \\
& \Delta y_{i}=g_{0}+\left(g_{1}-b_{1}\right) x_{i}+\left(g_{2}-b_{2}\right) y_{i}
\end{aligned}
$$




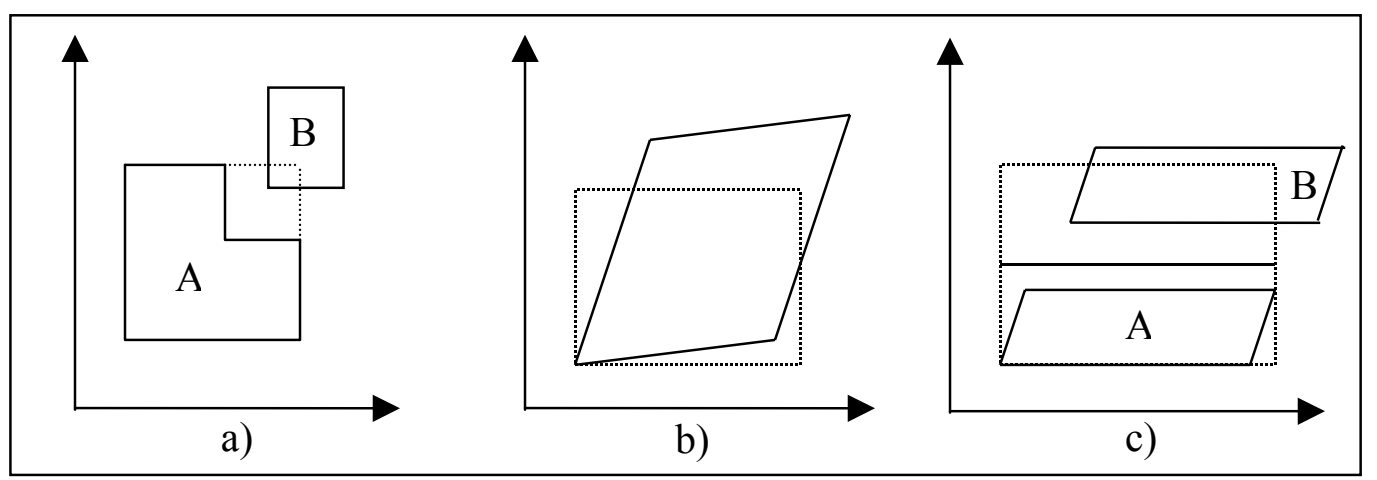

FIGURA 5.5 - Exemplos de modelos de deformação (Adaptado de: CHEN, 1983)

A preliminar identificação do modelo de deformação no espaço pode ser obtida utilizando-se uma transformação de similaridade ponderada, segundo CHEN \& CHRZANOWSKI (1996). Após o ajustamento das observações realizadas em duas épocas, o vetor deslocamento $(d)$ e sua matriz cofatora $\left(Q_{d}\right)$ são calculados por:

$$
\begin{gathered}
d=x_{2}-x_{1}, \\
\mathrm{Q}_{\mathrm{d}}=\mathrm{Q}_{\mathrm{x}_{2}}+\mathrm{Q}_{\mathrm{x}_{1}},
\end{gathered}
$$

onde $x_{i}$ e $Q_{x_{i}}$ são o vetor deslocamento das coordenadas ajustadas e sua matriz cofatora para a época $(i)$, respectivamente. Como os deslocamentos podem ser tendenciosos para um datum pré-selecionado, a solução encontra-se na obtenção de um novo datum pela transformação de similaridade ponderada:

$$
\begin{gathered}
d^{\prime}=\left(I-H\left(H^{T} W H\right)^{-1} H^{T} W\right) d=S d, \\
Q_{d^{\prime}}=S Q_{d^{\prime}} S^{T},
\end{gathered}
$$

onde $W$ é a matriz peso utilizada na definição do novo datum, e $H$ é a matriz cujo número de linhas é igual à dimensão do vetor deslocamento e cujo número de colunas é igual ao número de defeito de datum nas épocas observadas.

\subsubsection{Estimativa dos parâmetros de deformação dos modelos}

A determinação dos coeficientes de um modelo de deformação, ou seja, dos parâmetros de deformação $(\hat{c})$, utilizando-se de observações realizadas em várias épocas, é obtida, segundo CHRZANOWSKI et al. (1986), por:

$$
\hat{c}=\left(B^{T} P_{d} B\right)^{-1} B^{T} P_{d} d,
$$


onde $d$ é o vetor deslocamento, $P_{d}$ sua matriz peso e $B$ a matriz das derivadas parciais dos polinômios com relação às posições dos pontos.

\subsubsection{Comparação e seleção dos modelos}

Um modelo de deformação pode ser testado usando a função quadrática dos resíduos ( $\delta)$ obtidos na determinação de seus coeficientes, conforme CHRZANOWSKI \& CHEN (1986), como:

$$
\Delta R=\sum_{1}^{k} \delta_{i}^{T} P_{i} \delta_{i}
$$

onde $\Delta R=R_{1}-R_{0}$ são as formas quadráticas dos resíduos do ajustamento das equações de observação para dois modelos. A quantidade $\Delta R$ tem uma distribuição qui-quadrada com graus de liberdade de:

$$
d f_{c}=\sum_{1}^{k} r\left\{P_{i}\right\}-u+d_{f}
$$

onde $u$ é a dimensão do vetor das incógnitas, $r\left\{P_{i}\right\}$ é a característica da matriz peso, e $d_{f}$ é o número de defeitos de datum restante e de defeitos de configuração que não são determinados numa época.

O modelo de deformação é aceitável com um nível de confiança $(1-\alpha)$ se:

$$
\Delta R \leq \sigma_{0}^{2} \chi^{2}\left(d f_{c} ; \alpha\right)
$$

onde conhece-se o fator de variância a priori $\left(\sigma_{0}^{2}\right)$.

Se no modelo de deformação $(d=B c)$ tem-se $c=0$, o teste de hipótese é conhecido como teste de congruência global e considerado como o principal teste estatístico em análise de deformação, conforme CHEN \& CHRZANOWSKI (1986).

\subsubsection{Cálculo e representação das deformações}

Após a determinação dos parâmetros de deformação $(\hat{c})$, calculam-se as componentes de deformação, conforme SECORD (1995), por:

$$
\varepsilon_{g}=B_{\varepsilon} \hat{c}
$$


onde $B_{\varepsilon}$ corresponde à matriz das derivadas parciais dos polinômios com relação a $x$ ou $y$. As deformações principais, máxima e mínima, podem ser representadas graficamente, SECORD (1985). Valores negativos representam compressão, enquanto os positivos indicam uma extensão.

A representação gráfica é obtida dos resultados da análise de tendência ou do modelo de deformação.

\subsubsection{Procedimentos de cálculo}

Segundo CHEN (1983), os procedimentos de cálculo (um esquema é ilustrado na FIGURA 5.6) em análise de deformação são:

a) avaliação das observações usando o princípio do MINQUE (MInimum Norm Quadratic Unbiased Estimation) para obter as variâncias das observações e possíveis correlações das observações dentro de uma época ou entre épocas, se valores a priori não são disponíveis. (Este princípio não é tratado nesta pesquisa e detalhes do mesmo encontra-se em CHEN et al., 1990.);

b) ajustamento separado de cada época de observação, se as correlações das observações entre as épocas são negligenciáveis, caso contrário, ajustamento simultâneo de múltiplas épocas de observações é requerido para detecção de erros sistemáticos e outliers;

c) comparação de pares de épocas; uso do método de projeção ponderada iterativo (transformação de similaridade ponderada) para obter a "melhor" representação do campo de deslocamento;

d) seleção dos modelos de deformação baseado nas considerações a priori e no padrão de deslocamento;

e) estimativa dos coeficientes dos modelos de deformação e suas covariâncias usando todas as informações disponíveis;

f) teste global do modelo de deformação;

g) estimativa simultânea dos coeficientes do modelo de deformação no espaço e no tempo, se a análise de pares de épocas de observações sugere que é 
necessário. (Esta estimativa simultânea deve ser realizada se as observações são dispersas no tempo.);

h) comparação dos modelos e escolha do "melhor" modelo; cálculo dos parâmetros de deformação;

i) representação gráfica do modelo de deformação selecionado.

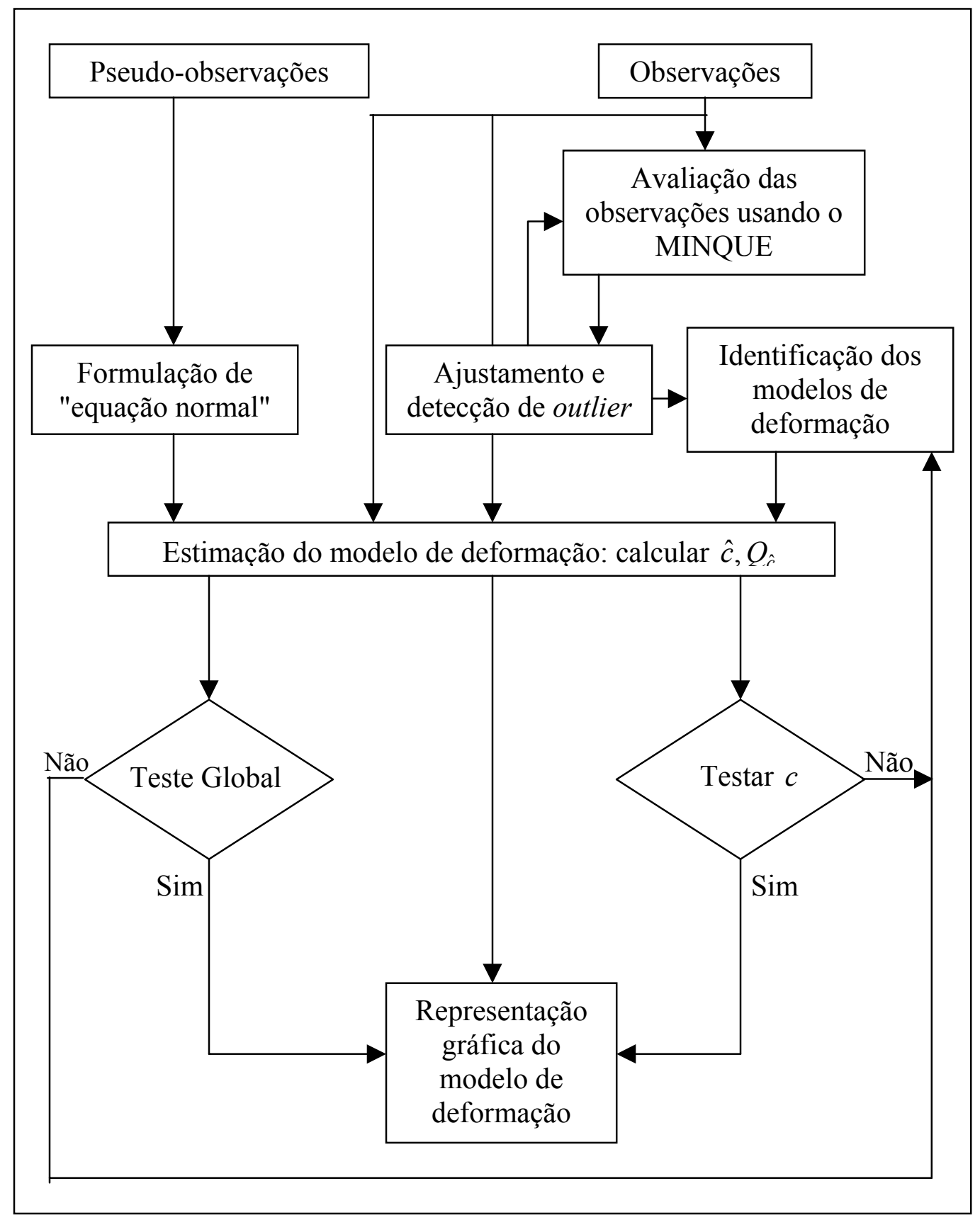

FIGURA 5.6 - Esquema dos procedimentos de cálculo (Adaptado de: CHEN, 1983) 


\subsection{Interpretação física de deformação}

Esta interpretação descreve as relações entre os efeitos causativos (forças internas e externas) e as deformações, CHRZANOWSKI \& CHEN (1990). A interpretação física de deformações é realizada para determinar o estado físico do corpo deformável, o estado de tensões internas e a relação carga-deformação

Uma vez que se estabelece a relação carga-deformação, os resultados da interpretação física podem ser utilizados para o desenvolvimento de modelos de predição, CHRZANOWSKI et al. (1991). Comparando-se as deformações preditas com os resultados da análise geométrica das deformações, obtém-se um melhor entendimento do mecanismo de deformação.

Há dois métodos para interpretação física da relação carga-deformação, conforme CHEN \& YANG (1996): o método estatístico e o método determinístico.

\subsubsection{Método estatístico}

O método estatístico analisa as correlações entre as deformações observadas e as cargas observadas (causas interna e externa que produzem deformação), CHEN \& YANG (1996).

As correlações são obtidas por análise estatística dos dados levantados, ou seja, primeiro coletam-se as observações (deformação e carga) para uma análise a posteriori. Utilizam estas informações na análise de regressão para estabelecer um modelo de predição empírico. A deformação prevista é obtida das cargas medidas no modelo predito. Este método não requer o conhecimento das propriedades dos materiais do corpo deformado.

Tem-se aplicado este método em engenharia, conforme CHRZANOWSKI \& CHEN (1990), por exemplo, em deformação de barragem, por várias décadas.

Um bom modelo de predição para este método é obtido somente se as observações das quantidades causativas (cargas) e das deformações forem suficientemente coletadas. Assim, uma grande quantidade de dados é necessária para obter um modelo confiável. 
CHEN \& YANG (1996) consideram este método menos interessante para o entendimento do mecanismo de deformação.

\subsubsection{Método determinístico}

O método determinístico utiliza informação de cargas, de propriedades dos materiais, da geometria do corpo, e das relações tensão-deformação, CHEN \& YANG (1996).

Este método não requer observações das deformações e utiliza-se das cargas, da geometria e das propriedades físicas do corpo deformado para predizer as deformações. A deformação esperada é obtida das cargas medidas.

Tem-se aplicado este método em engenharia civil e de estruturas por algum tempo, segundo CHEN \& YANG (1996), mas somente recentemente empregou-se na comunidade de levantamento.

As equações diferenciais utilizadas neste método, relacionando as forças externas com as tensões internas, são solucionadas com o uso de métodos numéricos, por exemplo, o método dos elementos finitos. Com os recursos computacionais atuais, a interpretação de deformações pelo método determinístico, utilizando-se do método dos elementos finitos, tem-se tornado realidade, CHEN (1983).

O conhecimento imperfeito das propriedades dos materiais, o modelo errado do comportamento do material e aproximações de cálculos são as causas que CHRZANOWSKI \& CHEN (1990) argumentam para as exatidões inferiores obtidas nas deformações preditas no método determinístico. CHEN \& YANG (1996) corroboram dizendo que as propriedades física e geométrica de um corpo deformado podem não ser completamente conhecidas, dificultando a interpretação física da deformação. Para solucionar este problema, desenvolveu-se um método denominado análise inversa de deformação.

\subsubsection{Análise inversa de deformação}

A análise inversa de deformação é utilizada para estimar algumas propriedades geométrica ou física, ou, as forças atuantes nas deformações observadas, CHEN \& 
YANG (1996). Este tipo de análise também pode ser útil no projeto de esquemas de monitoração de deformação.

Considerando-se os deslocamentos medidos nos elementos de um corpo, as observações geométricas $\left(l_{g}\right)$ expressam-se, segundo CHEN \& YANG (1996), por:

$$
l_{g}+v_{g}=H_{g} d,
$$

onde $v_{g}$ é o vetor dos erros que combinam os erros das observações e os erros do modelo do método dos elementos finitos, e $H_{g}$ é a correspondente matriz transformação. Para as medidas de deformação $(\varepsilon)$ num ponto do elemento, a equação de observação é:

$$
\varepsilon+v_{\varepsilon}=B_{e} d_{e}
$$

onde $d_{e}$ é o vetor dos deslocamentos dos pontos nodais no elemento, $v_{\varepsilon}$ é o vetor dos erros correspondentes, e $B_{e}$ é a matriz transformação deformação-deslocamento. A eq.(5.29) pode ser expressa como:

$$
\varepsilon+v_{\varepsilon}=B_{e} H_{e} d=H_{\varepsilon} d,
$$

onde $H_{e}$ é a matriz transformação de $d$ para $d_{e}$.

Considerando-se as observações de tensão $(\sigma)$ num ponto de um elemento (e), a equação de observação é:

$$
\sigma+v_{\sigma}=D B_{e} d_{e}
$$

onde $v_{\sigma}$ é o termo dos erros, e $D$ é a matriz constitutiva do material. A eq.(5.27) pode ser expressa como:

$$
\sigma+v_{\sigma}=D B_{e} H_{e} d=H_{\sigma} d .
$$

Tem-se da equação de equilíbrio para o objeto investigado que $K d=f$, onde $K$ é uma matriz em função das propriedades do material e da geometria do projeto, e $f$ é o vetor de carga. Para as observações geométricas e físicas, representadas pelo vetor $l$, na análise de deformação, estas observações relacionam-se com $d$ por:

$$
l+v=H d=H K^{-1} f,
$$

onde $v$ corresponde ao vetor dos erros. A eq.(5.33) é a equação básica para a análise inversa de deformação. 


\section{EXPERIMENTOS}

Neste capítulo, descrevem-se as experiências realizadas nas obras de engenharia (edifício e viaduto) e nas simulações (deslocamentos e deformações).

As etapas de otimização e interpretação física não são tratadas nestes experimentos, conforme mencionado no capítulo anterior.

\subsection{Edifício}

Esta obra de engenharia constitui-se num edifício de 18 pavimentos, denominado de Edifício Bali, da CONSTRINVEST Construtora e Comércio Ltda. (http://www.constrinvest.com.br), com aproximadamente 70 metros de altura. A FIGURA 6.1 ilustra esta estrutura.

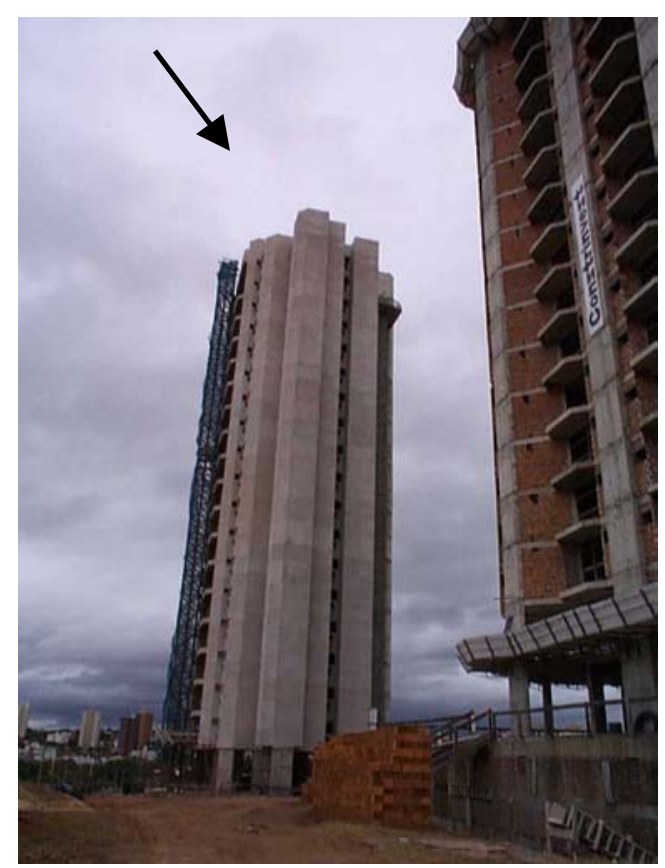

FIGURA 6.1 - Edifício Bali da Constrinvest 


\subsubsection{Descrição do experimento}

Após os contatos preliminares com a Construtora, visitou-se a obra, com o intuito de escolher os possíveis pontos a serem investigados. Juntamente com o construtor, optou-se por dois pontos para realizar as observações GPS, os quais localizam-se na casa de máquinas e na caixa d'água, denominados de PDCM e PDCX, respectivamente. Uma chapa com um dispositivo para centragem da antena GPS foi afixada em cada ponto. As FIGURAS 6.2 e 6.3 exibem estes pontos.

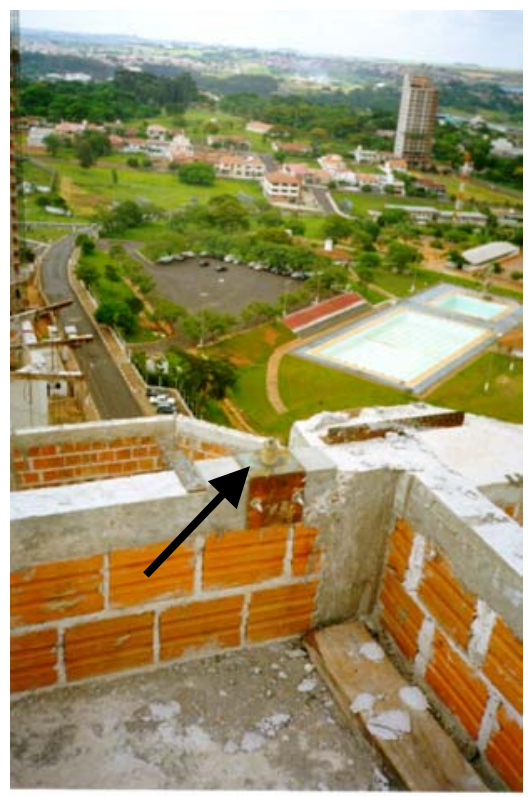

FIGURA 6.2 - Ponto PDCM

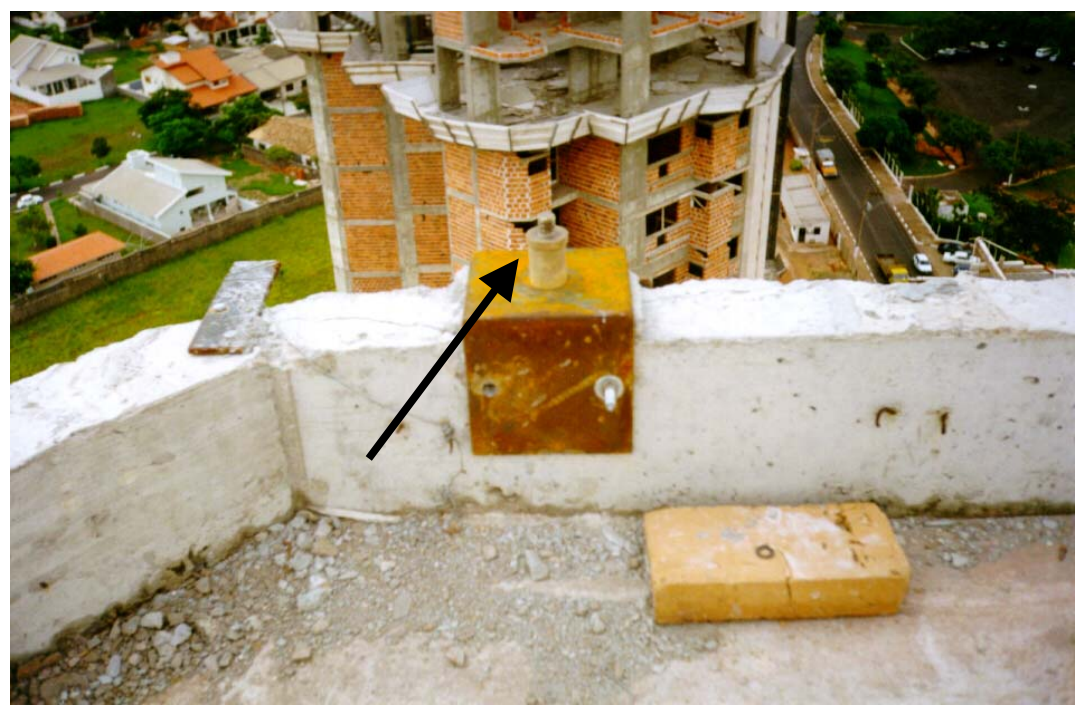

FIGURA 6.3 - Ponto PDCX 
A disposição dos pontos (PDCM, PDCX) na estrutura de engenharia é mostrada na FIGURA 6.4.

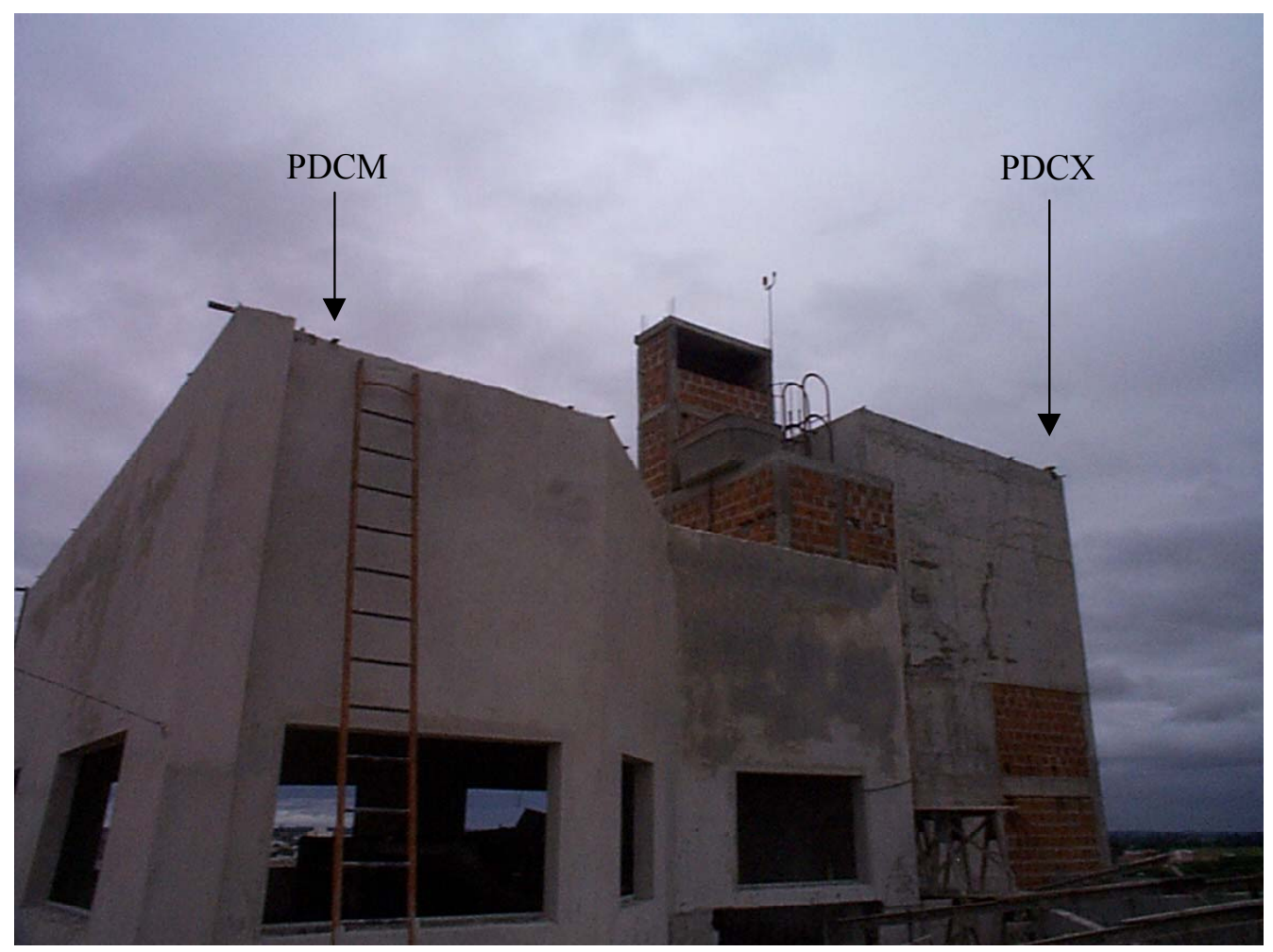

FIGURA 6.4 - Disposição dos pontos PDCM e PDCX

Além das observações coletadas nestes pontos, utilizam-se os dados da estação UEPP da RBMC, localizada no campus da FCT/UNESP. Uma imagem desta estação encontra-se na FIGURA 6.5.

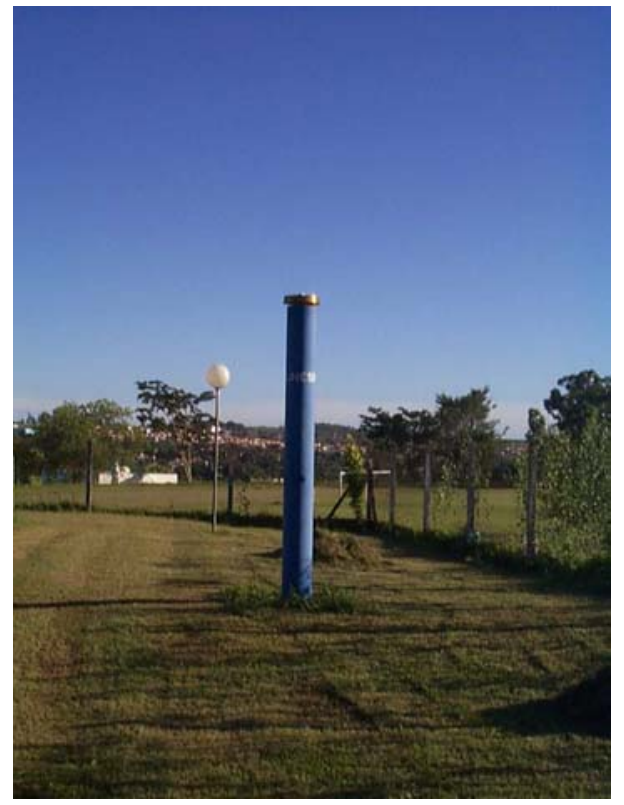

FIGURA 6.5 - Estação UEPP da RBMC 
Selecionados os pontos para coletar os dados GPS, decidiu-se pela taxa de rastreio de 15 segundos, compatível com a da estação UEPP.

Os receptores utilizados nesta pesquisa são: ASHTECH, modelo Z-XII, e TRIMBLE, modelos 4000SSI e 4600LS. As antenas conectadas nos respectivos equipamentos são: ASH700700C, DORNE MARGOLIN T e INTERNAL.

Definidos os pontos, o intervalo das observações e os equipamentos, realizouse a coleta dos dados GPS nos pontos escolhidos.

\subsubsection{Coleta e processamento de dados}

A fase de coleta de dados GPS correspondeu à instalação dos receptores e antenas na obra investigada. Em virtude da obra encontrar-se em fase de construção, durante o período da campanha de observações, subia-se a pé os 18 pavimentos para a colocação dos equipamentos nos pontos selecionados para realizar a pesquisa.

Após conectar os cabos de comunicação entre o aparelho, a antena e a fonte de energia, inicializava-se o receptor. Em razão da instabilidade da corrente elétrica no edifício, principalmente durante o funcionamento do elevador de serviço, o equipamento alimentava-se com bateria no período em que os funcionários da Construtora estavam trabalhando.

O modo de levantamento utilizado foi o estático, coletando dados GPS continuamente.

Para cada dia, gerava-se um arquivo com as observações coletadas. A finalização deste arquivo ocorria no dia consecutivo, transferindo os dados para o computador. Assim, em cada ponto do edifício, ou seja, nos pontos PDCM e PDCX, têm-se os arquivos diários para cada um.

Deve-se ressaltar que a maioria dos dados refere-se ao receptor Z-XII, pois este equipamento, além de possuir duas freqüências, oferece duas opções para fonte de alimentação: bateria e corrente elétrica. O receptor 4600LS possui apenas uma freqüência e oferece uma única opção para fonte de alimentação: bateria. Também deve-se considerar a capacidade de armazenar as observações, ou seja, a memória de cada equipamento. Como o receptor encontrava-se localizado no topo do edifício, neste experimento, com pouco ou nenhum obstáculo entre satélite e antena, esperava- 
se obter uma maior quantidade de sinais dos satélites GPS, e consequentemente, um maior número de dados armazenados. Para exemplificar, considere os dados coletados com o Z-XII, durante um dia (24 horas), no ponto PDCX (arquivo PDCX0471.00O); após conversão para o formato RINEX, tem-se um arquivo de 4,7 MB (MegaByte) (lembre-se que a taxa de rastreio foi de 15 segundos). Neste exemplo, há momentos em que se coleta dados de 12 satélites GPS ao mesmo tempo.

Em virtude do tamanho dos arquivos, atenção especial deve ser dedicada à armazenagem dos dados coletados, compactando-os e documentando-os adequadamente. Após a aquisição e a transferência dos dados para o computador, deve-se convertê-los para o formato RINEX e verificar a qualidade dos mesmos. Para realizar esta tarefa, utilizava-se o programa TEQC, conforme apresentado na seção 5.2 .

O processamento dos dados coletados com o Z-XII, realizava-se com o programa GIPSY, de acordo com a seção 5.2.2.2. A estratégia de processamento para os pontos PDCM e PDCX foi a fixed_precise_orbit+clock-TDP+Shadow, aqui denominada de fpo. O clock de referência foi o ALLGPS; não fixa nenhuma estação, ou seja, não existia o arquivo FIDUCIALS; os tipos de observáveis são LC e PC; e o objetivo final foi determinar a solução bias_fix.stacov. Utilizavam-se as efemérides precisas, não fiduciais, (*nnf.*) do JPL. Uma ilustração desta estratégia está na FIGURA 6.6.

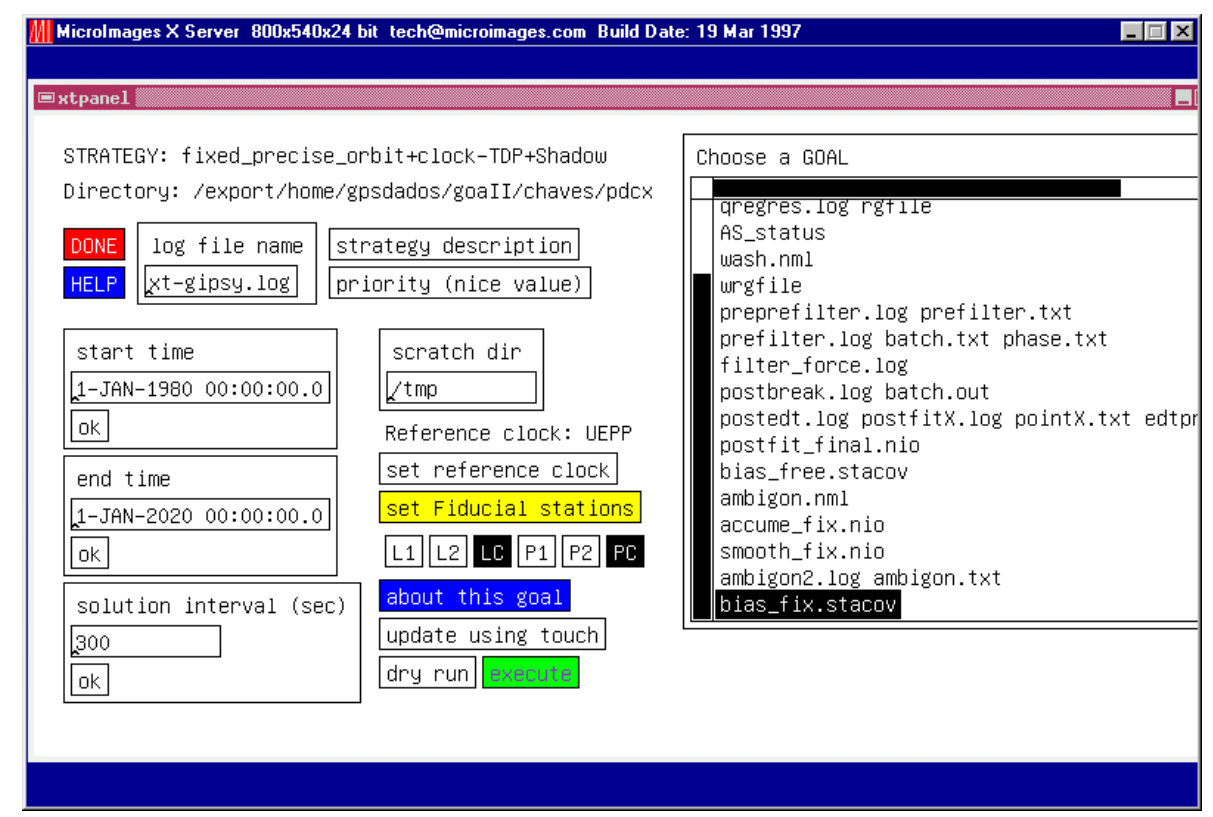

FIGURA 6.6 - Estratégia de processamento 
Ao obter as soluções bias_fix.stacov, também têm-se as soluções bias_free.stacov. Assim, há possibilidade de trabalhar com estes dois tipos soluções.

Com as soluções diárias processadas, transformava-as para um específico ITRF, com base no arquivo XFILE; gerando os arquivos bfree_qitrf e bfix_qitrf para cada solução processada.

Para exemplificar os tipos de soluções, considere os dados GPS coletados no ponto PDCX, no dia 15 de fevereiro de 2000, correspondendo ao dia do ano de número 046, armazenados no arquivo RINEX, PDCX0461.00O. Após realizar o processamento com o GIPSY, têm-se as soluções processadas (bias_free.stacov e bias_fix.stacov), as quais são renomeadas para d046_bias_free.stacov e d046_bias_fix.stacov. Transformando-as para um ITRF, obtém-se as soluções denominadas de d046_bfree_qitrf.stacov e d046_bfix_qitrf.stacov. Portanto, para cada dia observado, há um total de quatro arquivos a serem analisados.

As soluções pós-processadas são obtidas das processadas, com o programa stamrg, conforme apresentado na seção 5.2.2.2 (d). O arquivo de saída resultante da combinação de todas as soluções diárias (considerando um específico tipo de solução, p. ex.: bias_free.stacov) é o comb_bias_free.stacov. Relembrando, este arquivo corresponde a uma média ponderada de todos os arquivos (diários) de entrada, se não existir nenhuma época de referência definida (ou seja, sem a opção -v yymmmdd na execução do programa stamrg). Para os demais tipos de soluções, também haverá um solução combinada.

Utilizando as soluções (diárias) processadas e a solução (combinada) pósprocessada no programa statistics, obtém-se as seguintes soluções:

- as coordenadas geodésicas (GD) (LAT, LON, ALT) (latitude, longitude, altura geométrica) e geocêntricas (GC) (LAT, LON, RAD) (latitude, longitude, raio geocêntrico), para cada solução (diária e combinada);

- as componentes da base, com relação à primeira estação, em coordenadas cartesianas (XYZ), geodésicas locais (NEV: Norte, Este e Vertical) e LTU (Lenght-Transverse-Up), para cada solução (diária e combinada);

- as repetibilidades das componentes da base, com relação à primeira estação, em coordenadas geodésicas (GD), geocêntricas (GC), cartesianas (XYZ), geodésicas locais (NEV) e LTU, para a solução combinada; 
- as séries temporais (time series) das estações.

As coordenadas geodésicas referem-se ao elipsóide de referência WGS84, segundo GIPSY-OASIS (1996).

Então, obtém-se a solução combinada (comb_bias_free.stacov) dos arquivos diários ( $\mathrm{d}^{*}$ _bias_free.stacov) com o programa stamrg, e as soluções com o programa statistics, utilizando os dados de entrada das soluções diárias ( $\mathrm{d}^{*}$ _bias_free.stacov) para cálculo da repetibilidade, tomando-se por base o arquivo de referência da solução combinada (comb_bias_free.stacov), sobre o qual as repetibilidades são calculadas.

Também, realiza-se o processamento cinemático, conforme exposto na seção 5.2.2.2 (e), gerando as tabelas (TDPTABLE) para cada solução; obtendo-se, assim, os resultados entre épocas consecutivas. Após a coleta e o processamento dos dados GPS, analisam-se os resultados deste experimento.

\subsubsection{Resultados}

Nos experimentos praticados no edifício, processaram-se os dados coletados com diferentes estratégias, produzindo vários resultados, para cada tipo de solução, p. ex.: repetibilidade, série temporal e soluções dos processamentos cinemáticos. Estes resultados são enumerados a seguir:

a) estratégia fpo, para 23 dias de dados coletados na base PDCXUEPP, e para 04 dias para a base PDCMUEPP

a.1) repetibilidade das componentes da base em (XYZ), (NEV) e (L), para a solução combinada: TABELAS 6.1 e 6.2

TABELA 6.1 - Repetibilidade das componentes da base PDCXUEPP

\begin{tabular}{|l|c|c|c|c|c|c|c|}
\hline \multirow{2}{*}{ Solução } & \multicolumn{6}{|c|}{ Repetibilidade das componentes da base PDCXUEPP (cm) } \\
\cline { 2 - 8 } & $\mathrm{X}$ & $\mathrm{Y}$ & $\mathrm{Z}$ & $\mathrm{N}$ & $\mathrm{E}$ & $\mathrm{V}$ & $\mathrm{L}$ \\
\hline bias_free & 0.1501 & 0.0129 & 0.0160 & 0.0191 & 0.1219 & 0.0885 & 0.0503 \\
\hline bias_fix & 0.0325 & 0.0107 & 0.0094 & 0.0021 & 0.0210 & 0.0285 & 0.0111 \\
\hline bfree_qitrf & 0.0104 & 0.0110 & 0.0048 & 0.0021 & 0.0072 & 0.0138 & 0.0031 \\
\hline bfix_qitrf & 0.0065 & 0.0087 & 0.0042 & 0.0014 & 0.0020 & 0.0113 & 0.0017 \\
\hline
\end{tabular}

